\title{
Early detection of chronic obstructive pulmonary disease in general practice
}

Citation for published version (APA):

Dirven, J. A. M. (2016). Early detection of chronic obstructive pulmonary disease in general practice. [Doctoral Thesis, Maastricht University]. Datawyse / Universitaire Pers Maastricht. https://doi.org/10.26481/dis.20160429jd

Document status and date:

Published: 01/01/2016

DOI:

10.26481/dis.20160429jd

Document Version:

Publisher's PDF, also known as Version of record

Document license:

Unspecified

\section{Please check the document version of this publication:}

- A submitted manuscript is the version of the article upon submission and before peer-review. There can be important differences between the submitted version and the official published version of record.

People interested in the research are advised to contact the author for the final version of the publication, or visit the DOI to the publisher's website.

- The final author version and the galley proof are versions of the publication after peer review.

- The final published version features the final layout of the paper including the volume, issue and page numbers.

Link to publication

\footnotetext{
General rights rights.

- You may freely distribute the URL identifying the publication in the public portal. please follow below link for the End User Agreement:

www.umlib.nl/taverne-license

Take down policy

If you believe that this document breaches copyright please contact us at:

repository@maastrichtuniversity.nl

providing details and we will investigate your claim.
}

Copyright and moral rights for the publications made accessible in the public portal are retained by the authors and/or other copyright owners and it is a condition of accessing publications that users recognise and abide by the legal requirements associated with these

- Users may download and print one copy of any publication from the public portal for the purpose of private study or research.

- You may not further distribute the material or use it for any profit-making activity or commercial gain

If the publication is distributed under the terms of Article $25 \mathrm{fa}$ of the Dutch Copyright Act, indicated by the "Taverne" license above, 


\section{Early detection of}

\section{Chronic Obstructive Pulmonary}

\section{Disease in general practice}

Joseph A.M. Dirven 
${ }^{\circledR}$ Copyright 10 Jos Dirven, Maastricht 2016

Layout: Tiny Wouters

Cover: Rob van den Berg

Printed by: Datawyse | Universitaire Pers Maastricht

ISBN: 9789461595492

The research presented in this thesis was conducted at the School for Public Health and Primary Care (CAPHRI), Department of Family Medicine, Maastricht University.

CAPHRI participates in the Netherlands School of Primary Care Research (CaRe).

This PhD research was funded by the Lung Foundation Netherlands.

Financial support for printing of this thesis was kindly provided by Novivex.

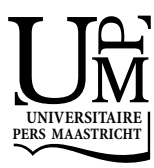




\title{
Early detection of \\ Chronic Obstructive Pulmonary Disease in general practice
}

\author{
PROEFSCHRIFT \\ ter verkrijging van de graad van doctor \\ aan de Universiteit Maastricht \\ op gezag van de Rector Magnificus, \\ Prof. dr. L.L.G. Soete, \\ volgens het besluit van het College van Decanen, \\ in het openbaar te verdedigen \\ op vrijdag 29 april 2016 om 14:00 uur \\ door \\ Jos Dirven
}




\section{Promotor}

Prof. dr. C.P. van Schayck

Prof. dr. J.W.M. Muris

\section{Copromotor}

Dr. H.J.Tange

\section{Beoordelingscommissie}

Prof. dr. G. Wesseling (voorzitter)

Prof. dr. J.A. Knottnerus

Prof. dr. N.H. Chavannes, Leids Universitair Medisch Centrum

Prof. dr. T. van der Molen, Rijksuniversiteit Groningen

Prof. dr. T. van der Weijden 
Aan mijn vader 



\section{Contents}

$\begin{array}{lll}\text { Chapter } 1 \text { General introduction } & 9\end{array}$

Chapter 2 COPD screening in general practice using a telephone 23 questionnaire

Chapter 3 Early detection of COPD in general practice: patient or practice managed? A randomised controlled trial of two strategies in different socioeconomic environments

Chapter 4 Early detection of COPD in general practice: Implementation, 57 workload and socioeconomic status

Chapter 5 An innovative COPD early detection programme in general practice; evaluating barriers to implementation

Chapter 6 General discussion

Summary

Samenvatting

Valorization

Dankwoord

Curriculum vitae 

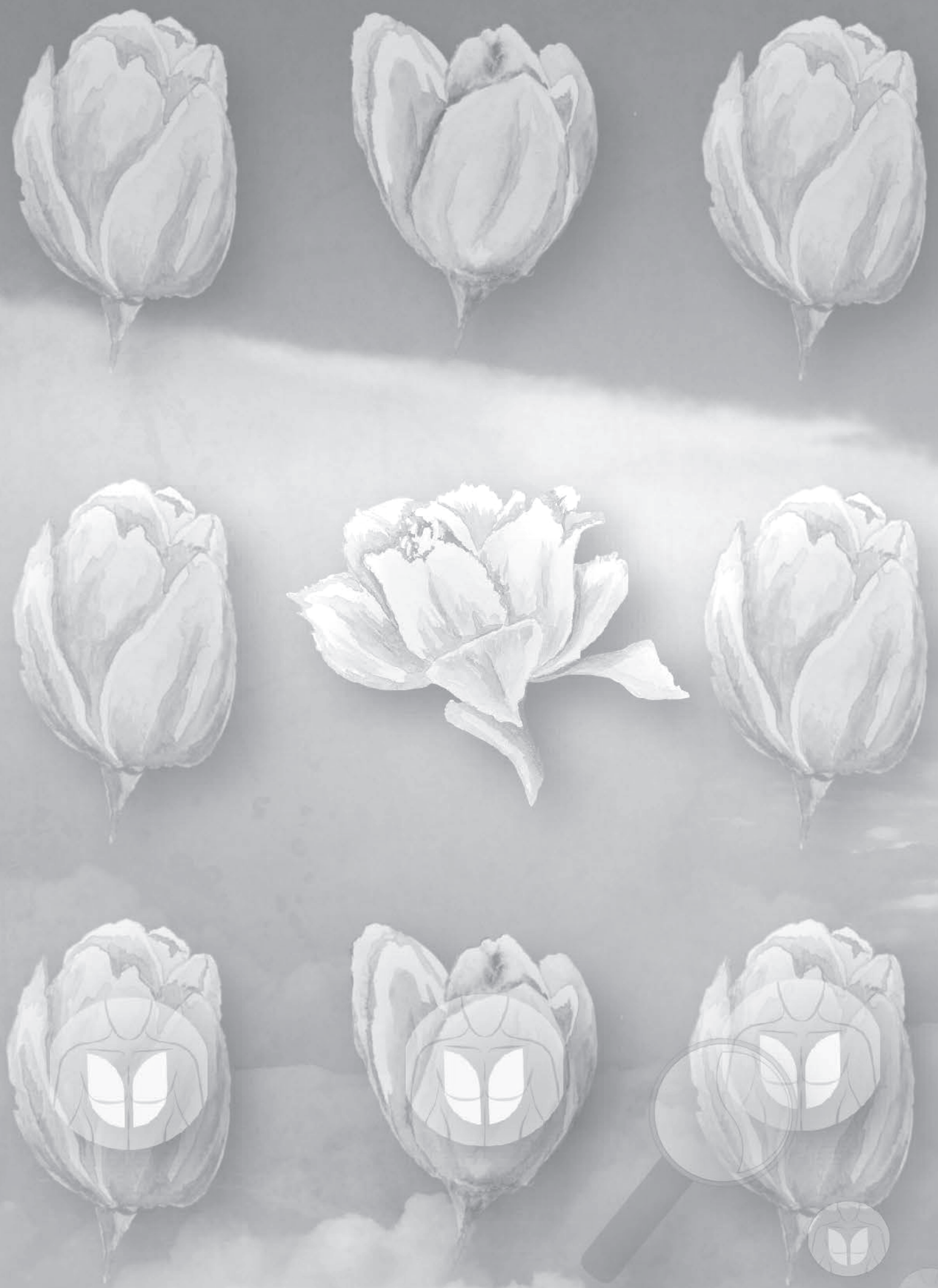


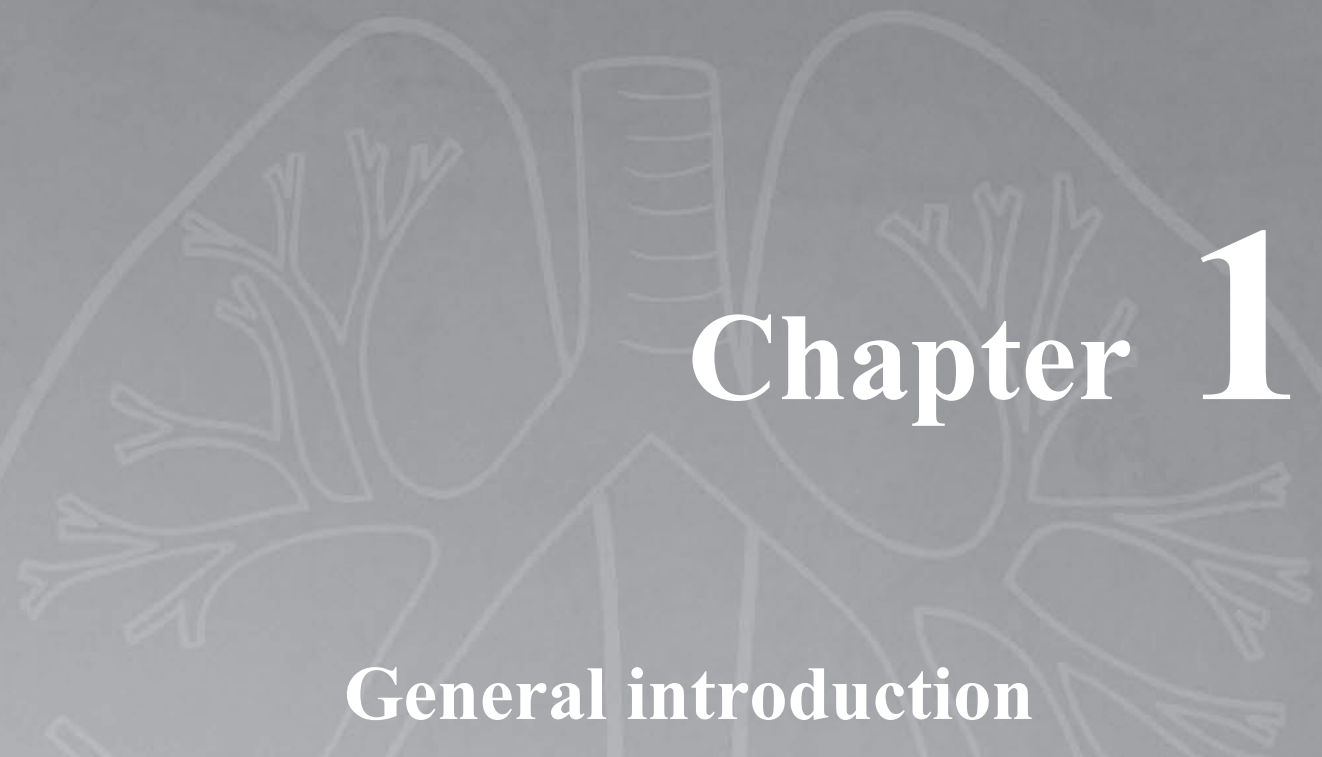

\section{General introduction}




\section{COPD is an underdiagnosed disease}

Chronic Obstructive Pulmonary Disease (COPD) is a common and preventable disease with increasing prevalence and mortality. (1) Based on population studies across all ages, the prevalence of COPD worldwide is $1 \%$, but above the age of 40 years it varies from $8 \%$ to $20 \%$, depending on the country. (1) According to the National Institute for Public Health and the Environment the 2011 prevalence in the Netherlands is $2.2 \%$. (2) Worldwide, COPD mortality ranked as the sixth cause of death in 1990 and is forecast to become the third leading cause of death by 2020. $(3,4)$ The increase in its prevalence and mortality in the Western world could be explained by the aging population, the smoking epidemic and the reduced mortality from other common causes of death (ischemic heart disease, infectious diseases). (1) COPD prevalence data show remarkable variation between countries and across studies, but more relevant for this thesis is that there is considerable difference in the prevalence rates found in population-based studies and those found in registration studies in primary care networks. A worldwide systematic review in 2006 showed a prevalence of COPD in adults aged of 40 years of $9-10 \%$ in population-based studies, against a prevalence of $4.1 \%$ in GP registers (5). The figures in a Dutch study in 2012 were in the population-based study $24 \%$ against $8.8 \%$ in the registry study in the over-40 group (6), whereas in the Continuous Morbidity Registration study in the Nijmegen region (also in the Netherlands), the 2006 prevalence of doctor-diagnosed COPD in the over-40 group was $5.4 \%$. (7) In line with these data, Soriano et al concluded that the estimated prevalence of COPD may be at least twice as high as that found in the practice-based GP registers. (8)

\section{Early diagnosis is important}

Early detection of COPD refers to diagnosing the disease at a stage where patients have not yet recognized their symptoms. This might result in finding more patients with especially mild and moderate stages of the disease. Early detection - when followed by early treatment - could lead to a decrease in the burden of illness for health care and patients in many Western populations, but might also decrease the 5-year mortality. (9) Early detection might reduce the number of exacerbations, which contribute substantially to the burden of this disease. From an economic perspective, prevention of exacerbations is extremely important as exacerbations generate the majority of costs due to the use of health care services. (10) They also have a significant impact on the patients' health status.(11) Another possible reason why early detection might 
be effective is the finding in the PLATINO study (12) and the BOLD study, (13) that when the initial diagnosis of COPD is established at age 60 or over, patients are already in a more severe stage of the disease. This might be a reason to aim for earlier diagnosis and treatment of COPD.

The need to include earlier detection of COPD in guidelines has been recognized and adopted by the American Thoracic Society (ATS) and the European Respiratory Society (ERS). (14) Both organizations concluded that more efforts should be made to diagnose COPD, especially when symptoms are mild, and at a stage when the diagnosis can be confirmed with spirometry. (1) Mounting evidence suggests that early detection, correct diagnosis, and early maintenance treatment of COPD, along with smoking cessation and increased daily physical activity, may help to control symptoms, delay disease progression and lead to better long-term outcomes. $(15,16)$ The room for improvement in early detection is largest for populations where the prevalence of practiceregistered COPD is lower than the prevalence based on population studies.

\section{Smoking}

Smoking is the main cause of COPD in the Western world (17) and it is also the major modifiable independent risk factor for COPD, (18) as lung function in smokers is known to decrease much faster than in never-smokers. $(19,20)$

The prevalence of COPD is considerably higher among current smokers and former smokers than among never smokers.(1) A few studies have examined the prevalence of COPD in smokers. The Lung Health Study (1993) in the USA found that $30 \%$ of 7300 smokers aged $35-60$ years had bronchial obstruction. (21) In 2001, a Polish Study by Zielinski to evaluate COPD prevalence by mass spirometry testing showed pulmonary obstruction in $25 \%$ of 11,000 smokers aged over 40 years. (22) Another study found that $30-50 \%$ of current smokers with more than 15 pack years in general practice have COPD. $(23,24,25)$

Early detection of COPD among smokers is especially important as advice from doctors, structured interventions from nurses and individual and group counselling have proved to be effective interventions to make patients give up smoking. $(26,27)$ Smokers with diagnosed pulmonary obstruction are more likely to quit smoking. (28)

Early detection of COPD combined with a smoking cessation intervention consisting of a simple brief advice turned out to be successful $(27,28)$ especially in a primary care setting. (29) 


\section{Low socioeconomic status}

Low socioeconomic status (SES) is an important and independent risk factor for COPD. (30) The prevalence of COPD is higher among people with low SES (31), whether they smoke or not. (32) Low SES correlates significantly with poorer lung function, even after adjustment for smoking status, occupational exposures and race or ethnic origin. (33) In the Netherlands, it is particularly among low-SES women aged 65 years and over that COPD prevalence is increasing. (7) This indicates the need to further investigate the role of SES in early detection of COPD.

\section{Possible explanations for underdiagnosis of COPD}

\section{Insufficient use of spirometry and inadequate diagnosis in general practice}

A spirometric test is one of the hallmark methods for a correct diagnosis of COPD. (1) In a study in general practice, only $45 \%$ of patients suspected of obstructive pulmonary diseases underwent spirometry. (34) In the United States of America, only $30-50 \%$ of the newly diagnosed COPD cases in general practice are confirmed by spirometry. (35) It has long been recommended that spirometry should be performed more often in general practice. (36) In addition, the diagnostic labelling of chronic respiratory disease in general practice is frequently inaccurate: when already diagnosed cases of asthma or COPD were re-evaluated using correct spirometry, $30 \%$ of the original diagnoses were found to be wrong and had to be adjusted. $(37,38)$

\section{Underpresentation of complaints}

It is remarkable that only $50-64 \%$ of patients enrolled in an early detection programme had recognized their own respiratory symptoms when they were diagnosed with COPD for the first time. $(23,39,40)$

In a 1996 study by Renwick, most of the patients with undetected pulmonary obstruction showed poor perception of their symptoms, as $76 \%$ of them had not realized their complaints before the interview. (41) After intensive investigation, van Schayck found that $7 \%$ of the population aged 40 years and over had symptoms of obstruction. Nevertheless, $66 \%$ of them had not presented their symptoms to a doctor before (underpresentation). (36) A 2007 study by Rabe showed that even in moderate COPD, $30-50 \%$ of cases remain undiagnosed, and about half of the COPD cases are only diagnosed at a severe stage, when dyspnea on exertion can no longer be ignored. (18) Cognitive dissonance has been suggested as an explanation of the poor perception and lack of presentation of symptoms to doctors. (42) Patients tend to justify their smoking behaviour by denying their symptoms, and many patients deny their symptoms 
so that they do not have to see a doctor. But even when the dyspnea is more severe, poor perceivers can show little inclination to accept medical advice.

Even if patients are known with an obstructive respiratory disease, many of them still take their complaints less seriously when visiting their doctor. This is reinforced by the response of many doctors who do not recognize the seriousness of the complaints and are inclined to send the patient off with the message that their condition is clinically stable. (43) These behaviours of both patients and doctors lead to underestimation of the health problem and of the burden of illness it represents.

\section{Early detection approach: screening or casefinding}

The studies reported in this thesis examined the early detection of COPD. The general principles of screening were originally set out in the late 1960s. (Table 1.1) Screening in medicine is a search process. An examination or a test is presented to asymptomatic people 'to classify them as likely or unlikely to have the disease that is the object of screening'. (44) To be effective, a screening test needs to be sufficiently sensitive and specific and must provide sufficient positive predictive value.

Basically, there are two approaches to the early detection of diseases: population-based screening and opportunistic screening (also called casefinding). (45)

Population-based screening concerns systematically inviting people for the specific purpose of screening them. This approach was originally directed at an entire population, offering a test to every individual. This was also referred to as 'universal screening', and was usually costly and inefficient when it concerned diseases with low prevalence. Epidemiological studies have, for instance, used this design to assess the prevalence of diabetes in the Netherlands. (46)

Opportunistic screening or casefinding involves screening individuals during routine health encounters, when the patient makes an appointment for a reason other than the condition or risk factor for which screening is offered. Opportunistic screening can also be targeted, for example at an age group of 40 and over. An advantage of opportunistic screening is that it requires less resources to perform the screening tests and follow-up. Casefinding in family practice offers patients a familiar health care setting, resulting in high acceptance and low cost. The drawback of casefinding is that it may provide incomplete coverage, since it depends on patient visits and clinical alertness among doctors and nurses. Both types of screening can be performed on every individual (universal screening) or on a subgroup of high-risk persons, which is 
also known as 'targeted' or 'selective' screening. (47) Which approach is chosen depends on the expected yield and workload of the procedure. (48)

The early detection method for COPD which is presented in this thesis can best be characterized as selective (or targeted) population-based screening. The provider of early detection in this method is the general practitioner, which has the advantage that the patient's medical history, diagnostic instruments, treatment and follow-up are all available. It is not preferable for screening surveys to use a public place (eg. spirometry offered in market places during World COPD Day), where it is made inefficient by accidental circumstances because of a lack of support and follow-up. (49)

Table 1.1

\begin{tabular}{|c|c|}
\hline & Principles of early disease detection by Wilson and Jungner (1968) \\
\hline 1 & The condition sought should be an important health problem \\
\hline 2 & There should be an accepted treatment for patients with recognized disease \\
\hline 3 & Facilities for diagnosis and treatment should be available \\
\hline 4 & There should be a latent or early symptomatic stage \\
\hline 5 & There should be a suitable test or examination \\
\hline 6 & The test should be acceptable to the population \\
\hline 7 & $\begin{array}{l}\text { The natural history of the condition including development from latent to declared } \\
\text { disease, should be adequately understood }\end{array}$ \\
\hline 8 & There should be an agreed policy on who to treat as patients \\
\hline 9 & $\begin{array}{l}\text { The cost of casefinding (including diagnosis and treatment of patients diagnosed) } \\
\text { should be economically balanced in relation to possible expenditure on medical care as a } \\
\text { whole }\end{array}$ \\
\hline 10 & Casefinding should be a continuing process and not a "once and for all" project \\
\hline
\end{tabular}

\section{Previous studies of early detection of COPD}

The literature provides seven studies reporting on the assessment of risk factors and preliminary symptoms to evaluate the yield of newly found COPD cases by casefinding or targeted screening.

The Belgian Didasco study (2004) was an opportunistic targeted screening (casefinding) study targeting all persons, smokers as well non-smokers, aged 35 to 70 years, who visited their GP's practice, and who were asked to complete a questionnaire and underwent hand-held spirometry. (50) The researchers found in 3408 visiting patients that $7.3 \%$ was known with asthma or COPD and that $23 \%(728)$ of all respondents were at risk of having pulmonary obstruction. The 
yield of obstructive lung disease cases after spirometry was $18 \%$ for those with one or more complaints and $4 \%$ for those remaining 2430 patients without complaints.

Van Schayck et al conducted a COPD casefinding study (51) by recruiting 650 patients between 35 and 70 years in two general practices. Smoking history and pulmonary drug use were assessed. After filling in a questionnaire about smoking and symptoms, 201 patients were found to be at risk, while 169 patients had an acceptable spirometric curve. Twenty-one percent of those aged over 40 years showed bronchial obstruction. The study of van Schayck at al demonstrated that smokers with cough had a greater risk of having COPD than smokers without cough, and that this risk increased with age: smokers with cough who were older than 60 had a $48 \%$ risk of having bronchial obstruction.

A study by Freeman et al. (52) recruited patients aged 40 and over with a history of smoking and/or asthma and/or respiratory medication. They selected 624 of 1195 identified persons; 369 of them consented to take part. Risk factors and symptoms were assessed by means of a questionnaire. The aim of the study was to test questions that could be used to identify ever-smokers likely to be at risk of having COPD. The yield of newly detected patients was $17 \%$. The analysis was valuable in identifying general question types that are most predictive of COPD.

A study by Calverley et al. (53) used a population-based dataset from the NHANES-III study, and comprised 7701 ever-smokers aged between 35 and 75 years. The yield of new COPD cases was $13 \%$.

A study by Martinez et al comprised a database of 697 patients recruited from general practices (64\%) and from specialist clinics (36\%) and included persons over 35 years without a history of respiratory problems. (54) The yield of newly found COPD cases was $38 \%$; this high value was probably due to the fact that they recruited subjects from specialist lung clinics as well as general practices.

The Danish Copenhagen COPD Screening Project by Lingsø et al in 2013 involved a targeted population-based COPD screening study, recruiting from general practices. (55) Of the 7103 persons aged 65 years and over, $81 \%$ filled in a questionnaire on smoking status and symptoms. If they had a history of smoking or a symptom of morning cough with sputum or dyspnoea, they were invited for spirometry (58.5\%). Forty percent of these underwent spirometry, and about $40 \%$ of them were diagnosed with COPD. A targeted population-based COPD screening study was conducted by Ulrik et al in 2011. (56) 335 general practices participated, and they included 3095 persons aged over 35, smokers as well as never-smokers and had at least one respiratory symptom of cough or sputum or wheezing or dyspnoea. All of these participants were considered to be at risk and underwent pre-bronchodilator spirometry. Airway obstruction was found in $35 \%$ of all enrolled subjects. 
These studies allow the conclusion that various methods of early COPD detection yield considerable numbers of newly detected COPD cases. But there are also limitations to these kinds of methods.

Spirometry criteria were not standardized in these studies. The guidelines of the American Thoracic Society and the European Respiratory Society have been revised several times so results of later studies cannot be easily compared with earlier ones. Revisions included FEV $1<80 \%$ of predicted; forced expiratory ratio (FER $<70 \%$ ) and post-bronchodilator values. Reversibility testing was not always performed. A few studies made use of hand-held spirometers whose reliability remains to be validated in other studies and which differ from the standard spirometric procedure and the recommendation to diagnose clinical COPD according to the GOLD guidelines. Studies also differed in terms of age limits for the included patients.

Most of the studies focused on early detection among smokers as a risk group. However, several studies after 2006 have pointed out the unexpected increase in COPD among non-smokers yielding $20-30 \%$ of all COPD diagnoses. $(57,28)$ The mentioned targeted population-based screening studies have been slightly modified from earlier 'universal screening' studies. This means that the target of assessment had become only a part of the whole population e.g. all persons aged 40 to 70 years, or all smokers, or all persons at high risk. Depending to the degree of selection the yield in targeted population-based studies might become smaller. Only a small proportion of the studies reporting the highest yields of new COPD diagnoses assessed outcome characteristics of implementation, in terms of e.g. workload or barriers for healthcare providers.

\section{Aims of this thesis}

From the above considerations it is evident that early detection of COPD makes sense and that previous screening initiatives have shown promising results. Successful elements of these initiatives could be reused as part of a new, easily accessible, early detection program for Dutch primary care. The aim of the studies reported in this thesis was to find a suitable strategy for this. To this end, we studied two alternative early detection strategies for COPD. In order of implementation effort, these were:

1. A telephone survey among the entire practice population aged 40-75 years to identify patients at risk of COPD.

2. An invitational questionnaire distributed among the entire practice population, including all persons aged 40-70 years, to identify persons at high risk of COPD. 
Both strategies included a follow-up programme in which patients at risk were invited for a spirometry test and a consultation with the doctor to confirm the diagnosis. We studied each strategy to assess its yield, feasibility and implementation barriers. The strategies have been published and are described in separate chapters of this thesis.

\section{Outline of this thesis}

Chapter 2 reports on a cross-sectional observational survey in two general practices with an estimated mean of 4200 patients. Targeted COPD screening was performed using a call centre to assess the risk of COPD by telephone. The yield of previously undetected COPD cases is reported, as well as the feasibility of this approach in both practices.

Chapter 3 describes a cluster-randomized controlled trial among general practices in which early detection of COPD was undertaken, using a written questionnaire to assess the risk of COPD. In the experimental condition, the practice actively invited high-risk patients for further diagnostics, while in the control condition, the initiative was left to the high-risk patients themselves. The yield of previously undetected COPD cases is reported, as well as the differences between practices with a low-SES signature and other practices.

Chapter 4 concerns a mixed-methods observational study among general practices, evaluating the feasibility of implementing the most promising screening approach, i.e. that is described in chapter 3 . Practice workload among different screening activities is assessed, and other potential barriers to implementation are detected.

Chapter $\mathbf{5}$ presents a qualitative study in which the implementation barriers detected in chapter 4 were elaborated in depth. This was done by conducting indepth interviews that were analysed using direct content analysis.

The general discussion in chapter 6 presents the key findings of the studies, evaluates main themes and draws overall conclusions. 


\section{References}

1. Global Initiative for Chronic Obstructive Lung Disease. Global strategy for diagnosis, management, and prevention of COPD,2014.

http://www.goldcopd.org/uploads/users/files/GOLD_2014_Jun11.pdf

2. Dutch National Institute for Public Health and the Environment, Bilthoven, The Netherlands, 2014.

http://www.nationaalkompas.nl/gezondheid-en-ziekte/ziekten-en-aandoeningen/ademhalingswegen/copd/omvang/

3. Murray CJ, Lopez AD. Alternative projections of mortality and disability by cause 1990-2020: Global Burden of Disease Study. Lancet 1997:349:1498-1504.

4. Lopez AD, Shibuya K, Rao C. The global burden of COPD: future COPD projections. Eur Respir J 2006;27:397-412.

5. Halbert RJ, Natoli JL, Gano A, Badamgarav E, Buist AS, Mannino DM. Global burden of COPD: systematic review and meta-analysis. Eur Respir J 2006;28:523-32.

6. Vanfleteren LEGW, Franssen FME, Wesseling G, Wouters EFM. The prevalence of chronic obstructive pulmonary disease in Maastricht, the Netherlands. Respir Med 2012;106:871-874.

7. Bischoff EWMA, Schermer TRJ, Bor H, Brown P, van Weel C, van den Bosch WJHM. Trends in COPD prevalence and exacerbation rates in Dutch primary care. $\mathrm{Br} J$ Gen Pract 2009;59:927-933.

8. Soriano JB, Zielinski J, Price D. Screening for and early detection of chronic obstructive pulmonary disease. Lancet 2009;374:721-732.

9. Wouters EF. Economic analysis of the Confronting COPD survey: an overview of results. Respir Med 2003;97 Suppl C: S3-14.

10. Sullivan SD, Ramsey SD, Lee TA. The economic burden of COPD. Chest 2000;117(2 Suppl): 5S-9S.

11. Seemungal TA, Donaldson GC, Paul EA, et al. Effect of exacerbation on quality of life in patients with chronic obstructive pulmonary disease. Am J Respir Crit Care Med 1998;157(5 Pt 1):1418-1422.

12. Menezes AMB, Perez-Padilla R, Jardim JRB, et al, for the PLATINO Team. Chronic obstructive pulmonary disease in five Latin American cities (the PLATINO study): a prevalence study. Lancet 2005;366:1875-1881.

13. Buist AS, McBurnie MA, Vollmer WM, et al, on behalf of the BOLD Collaborative Research Group. International variation in the prevalence of COPD (The BOLD Study): a populationbased prevalence study. Lancet 2007;370:741-750.

14. Celli BR, MacNee W. Standards for the diagnosis and treatment of patients with COPD: a summary of the ATS/ERS position paper. Eur Respir J 2004;23:932-946.

15. Price D, Freeman D, Cleland J, Kaplan A, Cerasoli F. Earlier diagnosis and earlier treatment of COPD in primary care. Prim Care Respir J 2011;20:15-22.

16. Miravitlles M, Soriano JB, Garcia-Rio F, et al. Prevalence of COPD in Spain: impact of undiagnosed COPD on quality of life and daily life activities. Thorax 2009;64:863-868.

17. Pauwels RA, Buist AS, Calverley PMA, Jenkins CR, Hurd SS, on behalf of the GOLD Scientific Committee. Global strategy for the diagnosis, management, and prevention of chronic obstructive pulmonary disease: NHLBI/WHO Global Initiative for Chronic Obstructive Lung Disease (GOLD) Workshop Summary. Am J Respir Crit Care Med 2001;163:1256-1276.

18. Rabe KF, Hurd S, Anzueto A, Barnes PJ, Buist SA, Calverley P, et al. Global strategy for the diagnosis, management, and prevention of chronic obstructive pulmonary disease: GOLD executive summary. Am J Respir Crit Care Med 2007;176:532-555.

19. Fletcher $\mathrm{C}$, Peto R, Tinker C.The natural history of chronic airflow obstruction. $B M J$ 1977;1:1645-1648.

20. Anthonissen NR, Conett JE, Kiley JP, Altose MD, Bailey WC, Buist AS. Effects of smoking intervention and the use of an inhaled anticholinergic bronchodilator on the rate of decline of FEV1: the lung health study. JAMA 1995;273:1497-1505. 
21. Connett JE, Bjornson-Benson WM, Daniels K. Recruitment of participants in the Lung Health Study, II: assessment of recruiting strategies. Controlled clinical trials 1993;14:38-51.

22. Zielinski J, Bednarek M. Early detection of COPD in a high-risk population using spirometric screening. Chest 2001;119:731-736.

23. Vandevoorde J, Verbanck S, Gijssels L, et al. Early detection of COPD: A case finding study in general practice. Respir Med 2007;101:525-530.

24. Lundback B, Lindberg A, Lindstrom $\mathrm{M}$, et al. Not 15 but $50 \%$ of smokers develop COPD. Report from the Obstructive Lung Disease in Northern Sweden Studies. Respir Med 2003;97:115-122.

25. Rennard SI, Vestbo J.COPD: the dangerous underestimate of $15 \%$. Lancet 2006;367: 1216-1219.

26. Lancaster T, Stead L, Silagy C, Sowden A. Effectiveness of interventions to help people stop smoking: findings from the Cochrane Library. BMJ 2000;321:355-358.

27. Stead LF, Bergson G, Lancaster T. Physician advice for smoking cessation. Cochrane Database Syst Rev 2008;1: CD000165.

28. Bednarek M, Gorecka D, Wielgomas J, Czajkowska-Malinowska M, Regula J, MieszkoFilipczyk G, et al. Smokers with airway obstruction are more likely to quit smoking. Thorax 2006;61:869-873.

29. Smith-Sivertsen T, Rortveit G. Should general practitioners screen smokers for COPD? Scand J Prim Health Care 2004;22:196-201.

30. Prescott E, Lange $P$, Vestbo J. Socioeconomic status, lung function and admission to hospital for COPD: results from the Copenhagen City Heart Study. Eur Respir J 1999;13:1109-1114.

31. Kanervisto M, Vasankari $T$, Laitinen $T$, Heliovaara $M$, Jousilahti $P$, Saarelainen $S$. Low socioeconomic status is associated with chronic obstructive airway diseases. Respir Med 2011;105:1140-1146.

32. Yin $\mathrm{P}$, Zhang $\mathrm{M}$, Li $\mathrm{Y}$, Jiang $\mathrm{Y}$, Zhao $\mathrm{W}$. Prevalence of COPD and its association with socioeconomic status in China: Findings from China Chronic Disease Risk Factor Surveillance 2007. BMC Public Health 2011;11:586.

33. Hegewald MJ, Crapo RO. Socioeconomic Status and Lung Function. Chest 2007;132: 1608-1614

34. Miravitlles M, de la Roza C, Morera J, Montemayor T, Gobartt E, Martin A, et al. Chronic respiratory symptoms, spirometry and knowledge of COPD among general population. Respir Med 2006;100:1973-1980.

35. Joo MJ, Lee TA, Weiss KB. Geographic variation of spirometry use in newly diagnosed COPD. Chest 2008;134:38-45.

36. van Schayck CP, van der Heijden FMMA, van den Boom G, Tirimanna $P$, van Herwaarden CLA. Underdiagnosis of asthma: is the doctor or the patient to blame? The DIMCA project. Thorax 2000;55:562-565.

37. Walker PP, Mitchell P, Diamantea F, Warburton CJ, Davies L. Effect of primary-care spirometry on the diagnosis and management of COPD. Eur Respir J 2006;28:945-952.

38. Jones RC, Dickson-Spillmann M, Mather MJ, Marks D, Shackell BS. Accuracy of diagnostic registers and management of chronic obstructive pulmonary disease: the Devon primary care audit. Respir Res 2008;9:62.

39. Stratelis G, Jakobsson P, Molstad S, Zetterstrom O. Early detection of COPD in primary care: screening by invitation of smokers aged 40 to 55 years. Br J Gen Pract 2004;54:201-206.

40. Bednarek M, Maciejewski J, Wozniak M, et al. Prevalence, severity and underdiagnosis of COPD in the primary care setting. Thorax 2008;63:402-407.

41. Renwick DS, Conolly MJ. Prevalence and treatment of chronic airways obstruction in adults over the age of 45. Thorax 1996;51:164-168.

42. Festinger L. A theory of cognitive dissonance. Stanford, Calif.: Stanford University Press, 1962.

43. Juniper EF, Chauhan A, Neville E, Chatterjee A, Svensson K, Mörk AC, Ståhl E. Clinicians tend to overestimate improvements in asthma control: an unexpected observation. Prim Care Respir J 2004;13:181-184. 
44. Morrison AS. Screening. In: Modern Epidemiology (second edition), KJ Rothman and SJ Greenland, editors, pp 499-518, Lippincott Williams and Wilkins, ISBN 0-316-75780-2. Philadelphia, USA. 1998.

45. Wilson JMG, Jungner G. "Principles of early disease detection." World Health Organization. Geneva, Public Health Papers 1968;34:27-39.

46. Mooy JM, Grootenhuis PA, de Vries H, Valkenburg HA, Bouter IM, Kostense PJ et al. Prevalence and determinants of glucose intolerance in a Dutch Caucasian population. The Hoorn Study. Diabetes Care 1995;18:1270-1273.

47. Evans PH, Wright C, Pereira Gray DJ, Langley P. Type 2 Diabetes Mellitus in Family Practice: Prevention and screening. In: Zimering MB, editor. Topics in the Prevention, Treatment and Complications of Type 2 Diabetes. Reijka, Croatia: InTech; 2011

48. Rose G. Sick individuals and sick populations. Int J of Epidemiology 1985;14:32-38

49. World Health Organization. Screening for Type-2 Diabetes. Report of the World Health Organization and International Diabetes Federation meeting. 2003. Geneva. World Health Organization. http://www.who.int/diabetes/publications/en/

50. Buffels J, Degryse J, Liistro G. Diagnostic certainty, co-morbidity and medication in a primary care population with presumed airway obstruction: the DIDASCO2 study. Prim Care Respir $J$ 2009;18:34-40.

51. Schayck CP van, Loozen JM, Wagena E, et al. Detecting patients at a high risk of developing chronic obstructive pulmonary disease in general practice: cross sectional case finding study. BMJ 2002;324:1370.

52. Freeman D, Nordyke RJ, Isonaka S, Nonikov DV, Maroni JM, Price D, et al. Questions for COPD diagnostic screening in a primary care setting. Respir Med 2005;99:1311-1318.

53. Calverley PM, Nordyke RJ, Halbert RJ, Isonaka S, Nonikov D. Development of a populationbased screening questionnaire for COPD. COPD 2005;2:225-232.

54. Martinez FJ, Raczek AE, Seifer FD, Conoscenti CS, Curtice TG, D'Eletto T, et al. Development and initial validation of a self-scored COPD Population Screener Questionnaire (COPD-PS). COPD 2008:5:85-95.

55. Lyngsø AM, Gottlieb V, Backer V, Nybo B, Østergaard MS, Jørgensen HL, Frølich A: Early detection of COPD in primary care: the Copenhagen COPD screening project. COPD 2013;10:208-215.

56. Ulrik CS, Løkke A, Dahl R, Dollerup J, Hansen G, Cording PH, Andersen KK, TOP study group: Early detection of COPD in general practice. Int $J$ Chron Obstruct Pulmon Dis 2011;6:123-127.

57. Salvi SS, Barnes PJ. Chronic obstructive pulmonary disease in non-smokers. Lancet 2009;374:733-743. 

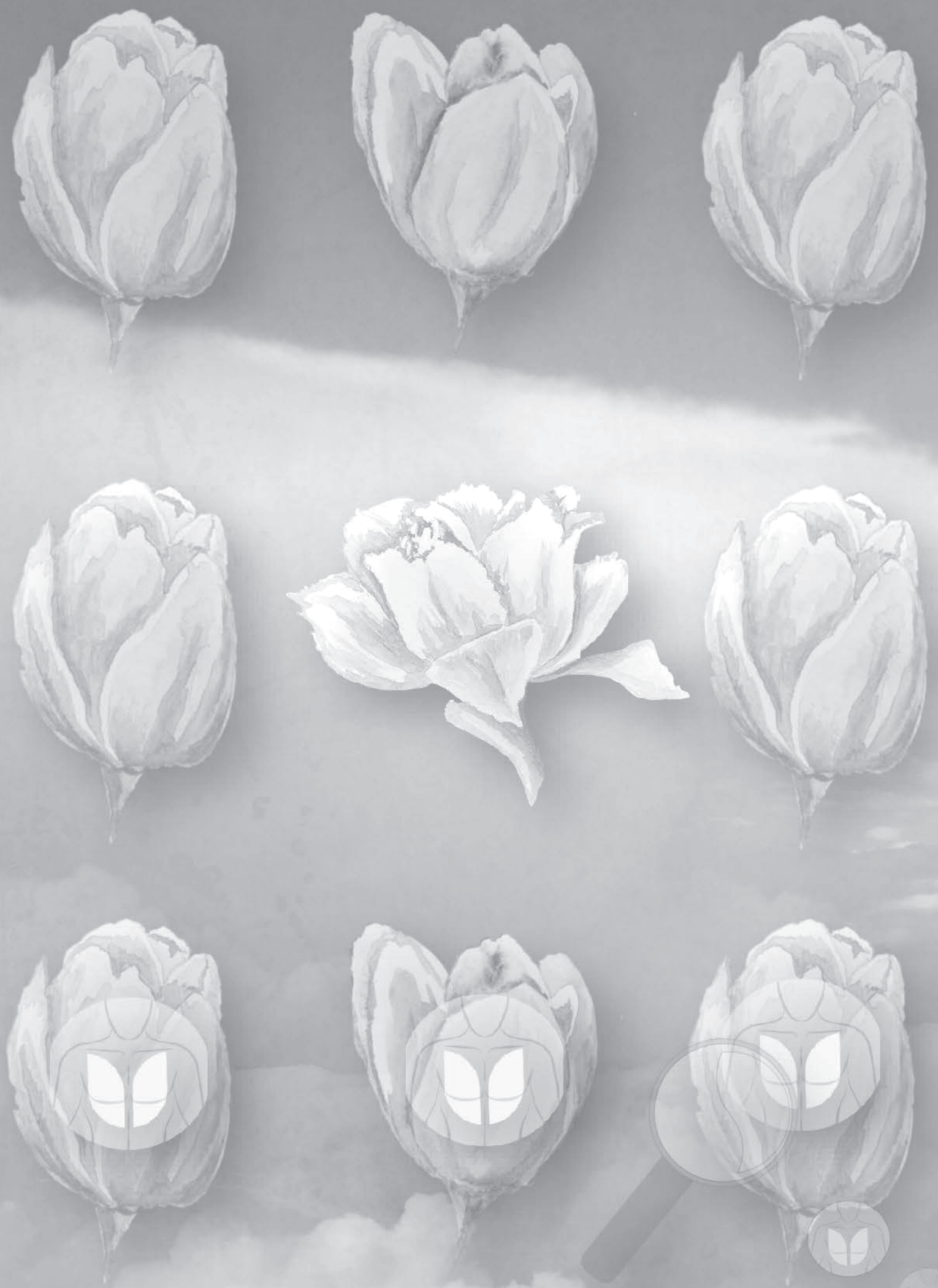


\section{Chapter}

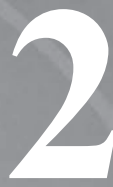

COPD screening in general practice using a telephone questionnaire

J.A.M. Dirven, J.W.M. Muris, C.P. van Schayck Journal of Chronic Obstructive Pulmonary Disease 2010;7:352-359 


\section{Abstract}

Introduction

Chronic obstructive pulmonary disease (COPD) is a growing health problem, and an underestimated and underdiagnosed disease in primary care. The aim of this survey was to study the feasibility of detecting undiagnosed COPD patients in the general practice population with the aid of a telephone questionnaire.

Method

The study was held in 2 general practices in the Netherlands. During 2 weeks, all patients registered with these 2 practices and aged between 40 and 75 years were contacted through a call center. Persons known with a previous history or diagnosis of COPD or asthma or comorbidity were excluded from the telephone list. The telephone interview used the Respiratory Health Screening Questionnaire (DB Price, 2006). Based on the score on this instrument, respondents were classified as having a low, moderate or high risk of having COPD. Smoking behaviour and BMI were also recorded. Patients with medium and high risk for COPD were invited for spirometry, performed by 2 experienced registerednurses.

Results

The results of the telephone interview and spirometric findings were assessed by the attending GP, who established the final diagnosis. The call center reached 1032 persons, 813 of whom answered the questions. The percentage of smokers was $49.2 \%$, with an average number of pack-years of 17.9 $(\mathrm{SD}=17)$;mean BMI was 26.1. Spirometry and analysis by the GP showed that $15.7 \%$ of the medium-risk group had previously undiagnosed COPD, versus $39.6 \%$ of the high-risk group.

Conclusion

The number of undiagnosed COPD patients in the general practice population is considerable. Case finding can focus on moderate- and high-risk groups after telephone risk assessment. 


\section{Introduction}

There is currently a worldwide increase in the prevalence of COPD. (1) The true prevalence of COPD in the Netherlands is higher than that found in the official registrations of COPD patients in general practices. $(2,3)$ About $10 \%$ of the population above the age of 40 show symptoms compatible with COPD. (4) Only $26 \%$ of all COPD patients show clinical signs of the disease. (5) About 25-50\% of all these COPD patients are known as such to their doctor. (6) There are various reasons why COPD patients do not visit their doctor. One reason is that many people withCOPDare unaware of their condition. Doctors could play a pioneering role in changing this, through active case finding. Spirometry is not very frequently performed in general practices, and should be used more often to detect more COPD cases. $(7,8)$ Early detection could be important to prevent further deterioration of lung function. This is particularly important for smokers, as the lung function in smokers decreases much faster. $(9,10)$ There is also evidence that smoking cessation advice based on personal risk factors (packyears, BMI, symptoms, lung function) is more successful than general advice. (11) There have been several initiatives to develop case-finding programmes to detect COPD. There have been a number of surveys, but these have shown a wide variety in approach and outcome in different clinical settings. (12-19) Studies have concentrated on selected groups of persons who consulted their general practitioner (GP), for instance through surveys in the waiting room, or on a group of smokers. Unfortunately, the presence or absence of clinical findings was not helpful to detect airflow obstruction. (13) Van Schayck proposed that simple self-administered questionnaires can be used to identify persons for whom spirometric testing may be especially appropriate. $(14,15)$ Vandervoorde found $30 \%$ undetected COPD among waiting-room patients. (16) Geijer found a prevalence of $34 \%$ of undetected COPD in male smokers (30\% GOLD I and $4 \%$ GOLD II). (17) Stratelis showed that $27 \%$ of smokers had COPD. (18) Piperno found moderate or severe COPD in $53 \%$ of smokers. (19)

Price and colleagues developed the Respiratory Health Screening Questionnaire as a tool to detect COPD in the general practice population. $(20,21)$ However, there is some controversy in the literature about the value of the RHS questionnaire in primary care populations. After external validation, Kotz et al. found that the RHSQ was not suitable to assess the risk of COPD in a population where only smokers are examined. (22) Development of a standardized questionnaire and scoring list will require further study, including prospective validation of items in different appropriate clinical settings.

Case finding in a general practice entails costs and extra workload. Previous research suggests that screening of the whole population with questionnaires and including spirometry is not feasible and not cost-effective. $(23,24)$ Although 
COPD screening in routine general practice is not regarded as a feasible option, the cost of detecting a COPD case is relatively low. $(15,25,26)$

The aim of the present survey was to study the feasibility of COPD detection among all persons aged 40 to 75 years who were registered with 2 general practices, by applying the RHS questionnaire through a call center. The secondary aim was to assess the prevalence of previously unknown COPD in mediumand high-risk groups.

The research questions were:

How many persons are found to be at risk of having COPD in a general practice population, if every person aged 40 to 75 years who is not known to have COPD is assessed by telephone using the RHS questionnaire?

In how many persons who are at risk according to the RHSQ scores can the presence of COPD be confirmed? What extra workload does this approach involve, in terms of time?

\section{Methods}

A cross-sectional observational study was undertaken in two general practices sharing the same building. The 2 practices are very similar and include an estimated mean of 4,200 patients. The surgery is located in a rural village in the center of the Netherlands.

All patients aged between 40 and 75 years were extracted from the electronic patient files. We excluded those persons who had already been diagnosed with asthma or COPD, those who had serious and complicated diseases such as a history of lung cancer, pneumoconiosis, tuberculosis, bronchiectasis or pneumonectomy, as well as those using oxygen supplementation and those who were unable to visit the practice due to lack of mobility. An experienced call center was selected, which operated in accordance with Dutch privacy regulations. The call center was asked to contact the eligible persons by telephone.

Unknown telephone numbers were, where possible, traced through the national internet telephone book. Known telephone numbers where there was no answer were called up to 3 times, including in the evenings up to $8 \mathrm{pm}$. No attempt was made to contact those for whom no telephone number was available. All persons were phoned personally. All respondents were asked to give informed consent. They were also told that the questions were asked on behalf of their own GP. It was explained to them that the purpose of the survey was to detect COPD, even if they had no complaints. They were also told that the outcome would be used to determine whether they would need to undergo spirometry at the surgery at a later date. 
The average phone call was planned to last 6 minutes. During the telephone call, data were directly entered in Excel. The call center used 8 operators for the interviews. Within 2 weeks, all eligible persons had been contacted. After data processing, an RHS risk score was calculated for each respondent.

Only respondents at medium and high risk were then invited for spirometry by the practice receptionists, who tried to contact them by phone for a maximum of three times, on different days, between 9 am and $5 \mathrm{pm}$. Two well-trained, qualified asthma/COPD practice nurses performed spirometry over a period of 4 months. Each spirometry session took 30 minutes. Three evening spirometry sessions were offered to people who were too busy during the daytime.

The practice nurse and the doctor evaluated all spirometries with the accompanying questionnaires and clinical findings once a week. The GP also used his own Electronic Medical Record (EMD). Each new diagnosis was assessed by this GP with a special interest in COPD.

\section{Instruments}

The telephone calls used the 'Respiratory Health Screening' questionnaire (RHSQ) (see Table 2.1). This is a short list with ten questions relating to important determinants of COPD. The criteria in this list are age, smoking, BMI, coughing, wheezing, sputum and allergy. The answers on the Respiratory Health Screening questionnaire were transformed into a score; therefore, the validated COPD case finding scorecard has been used. (21) First, 0-16.5 points was regarded as a low score, 16.5-19.5 points was a medium score and more than 19.5 points was a high score. Only respondents with medium or high scores were considered 'at risk' of having COPD, and only these 2 groups were asked to visit the surgery for spirometry. No spirometry was carried out in the low-risk group.

Each spirometry consultation took 30 minutes, and was based on the COPD guideline of the Dutch College of General Practitioners. Spirometry was performed before and 15 minutes after bronchodilation with four puffs of salbutamol $100 \mathrm{mcg}$ by dosisaerosol. We used the Welch Allyn spirometer that was calibrated each morning. The FER index (=Forced Expiratory Rate) was assessed using post-bronchodilatory data. Significant bronchodilation was considered present when FEV 1 post minus $F E V_{1}$ pre, divided by $F E_{1}$ pre and multiplied by $100 \%$ was $12 \%$ or more. The diagnosis of COPD was accepted when the FER index was lower than $70 \%$, after reading the flow volume curve and the time volume curve by a qualified nurse. These results in the presence of clinical signs suggestive of COPD were assessed by the attending doctor. The doctor also evaluated whether asthma could be diagnosed. 
Table 2.1 Respiratory Health Screening Questionnaire and Scorecard.

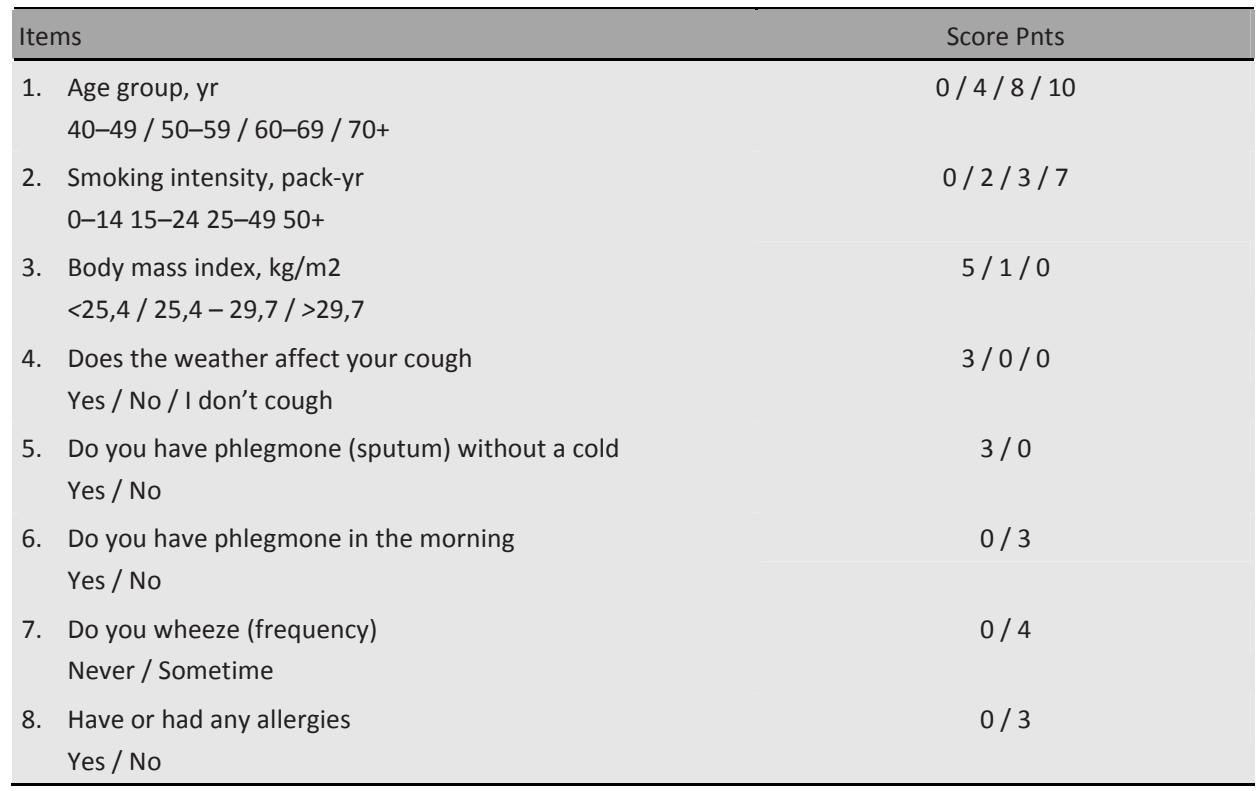

\section{Results}

Of the 1,412 patients aged 40-75 years registered with the general practices, 1,252 were not known with a diagnosis of COPD or asthma, or serious invalidating co-morbidity leading to immobility. Two hundred-and-twenty persons could not be reached by telephone, so 1,032 persons were eventually contacted. Of these, $813(=78.8 \%)$ answered all the questions in the questionnaire as read to them by the call center operators (diagram 2.1). Reasons for nonresponsewere "refusing to answer questionnaires" or being unable to answer all items of the questionnaire. Some respondents refused to answer because they did not experience any respiratory symptoms or felt healthy and therefore felt that they could not answer the screening questions. Some of them thought that COPD had to do with smoking, and since they did not smoke, further questions did not make sense to them.

The questionnaire scores identified a high-risk group (11\%), a medium-risk group (20\%) and a low-risk group (69\%) (diagram 2.2). Men and those aged over 60 were overrepresented in the high- and medium-risk groups (Table 2.2). Forty-nine percent of the entire study population were former and/or current 
smokers, against $75 \%$ of the high-risk group. The smokers had an average of 31 pack-years. The medium-risk group included $59 \%$ smokers, with an average of 23 pack-years. Allergy was less frequent in the high- and medium-risk groups than in the study population as a whole, while coughing and wheezing were much more frequent than in the total study population.

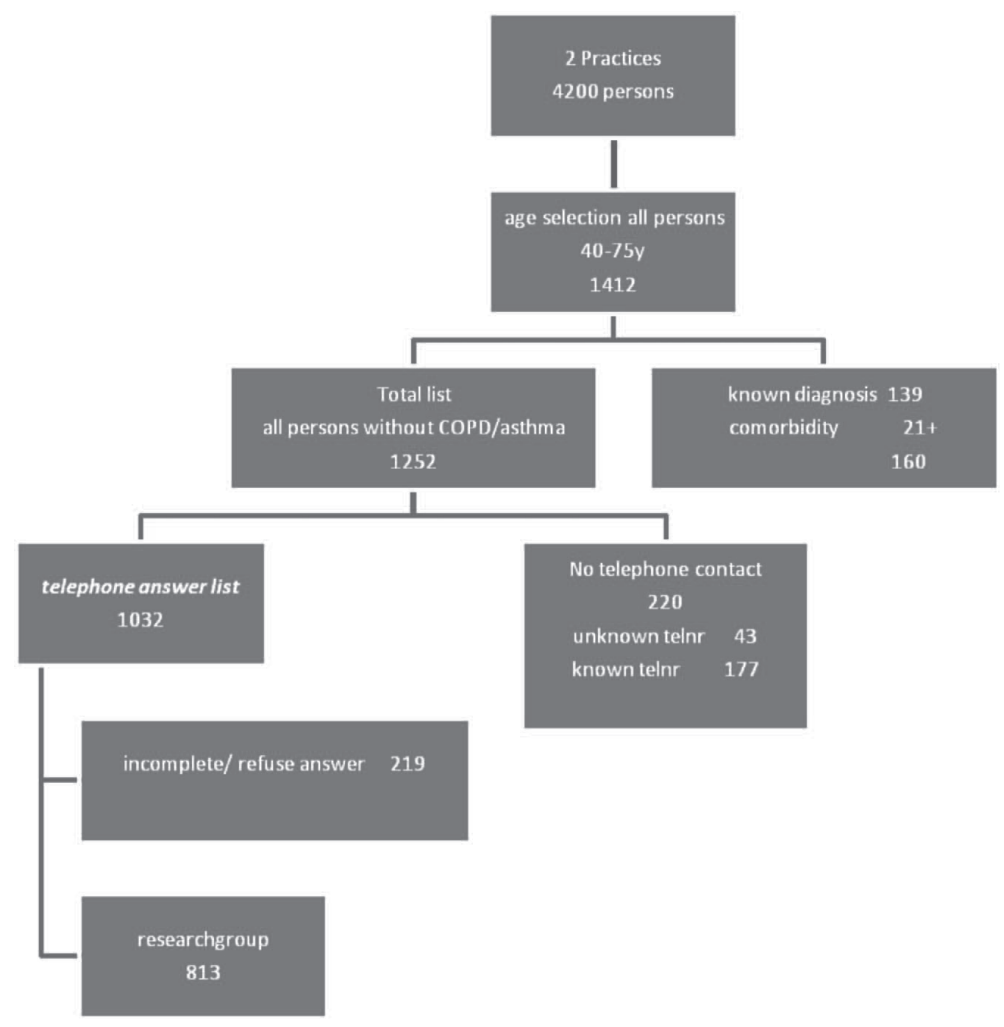

Diagram 2.1 Flowchart.

Sixty-seven percent $67 \%$ of the high-risk group and $54 \%$ of the in the mediumrisk group underwent spirometry (diagram 2.2). Most of those who did not show up for spirometry could not be reached via their home telephone number during the daytime. Of those who were contacted, hardly anyone refused spirometry in the end. Ten persons (two in the high-risk group and eight in the medium-risk group) were excluded from analysis because no valid spirometric findings could be obtained. A diagnosis of COPD was established in $39.6 \%$ of the highrisk group and $15.7 \%$ of the medium-risk group (diagram 2.2). 


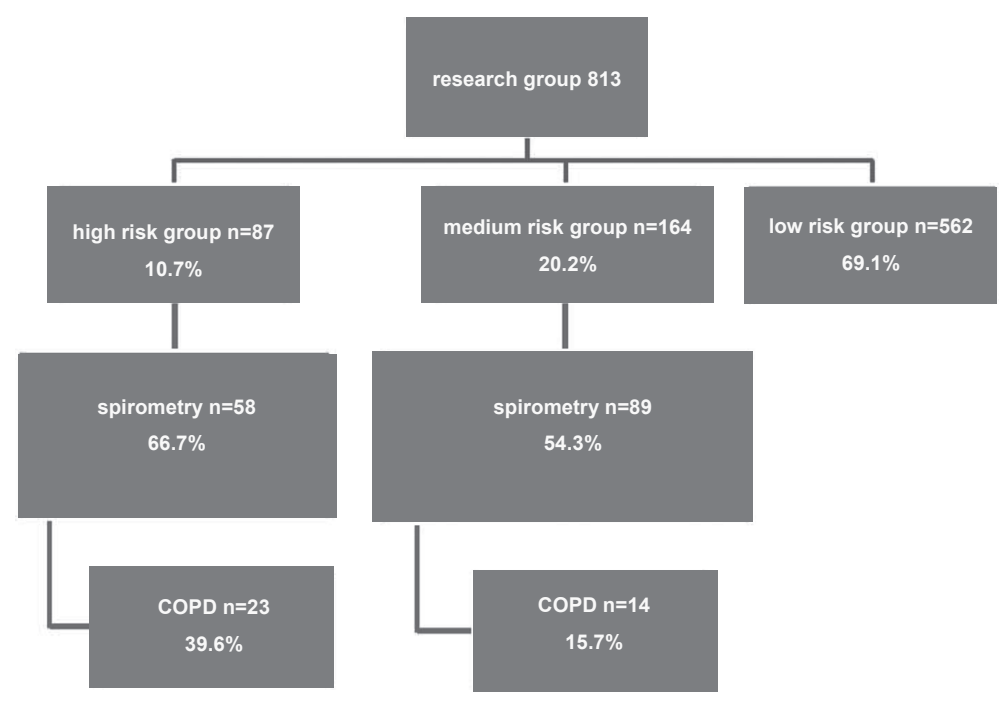

Diagram 2.2 'Research group' outcome after telephone questionnaire.

Even in the high-risk group, the score in terms of symptoms and allergy was rather low (Table 2.2). Very few of those in whom COPD was detected by this survey mentioned symptoms: $36 \%$ of them had a cough, $31 \%$ had productive sputum and $44 \%$ had symptoms of wheezing. Eighty-nine percent of them were current smokers. They had an average BMI of 24.6.

In both risk groups, about two thirds had GOLD-I COPD and about one third had GOLD-II COPD. GOLD III and IV were not detected. In the newly detected COPD group, $30.6 \%$ had COPD and asthma. The average $\mathrm{FEV}_{1}$ was $88.3 \%$ and FER 63.1\%.(Table 2.3)

The results after questionnaires in this survey identified a risk of having COPD in $31 \%$ of the study population aged 40 to 75 years. Combining both risk groups after spirometry, $25 \%$ of the respondents were newly diagnosed with COPD. According to these data, 4 spirometries would be needed in the total risk group to find one COPD diagnosis.

The prevalence of COPD in the survey practices was $3.3 \%(139 / 4200)$ before the screening, rising to $4.2 \%(37 / 4200=0.9 \%)$ after the screening. The newly detected COPD patients comprised $21 \%$ of all COPD patients. 
Table 2.2 Distribution in the population of risk on COPD according to questionnaire data.

\begin{tabular}{|c|c|c|c|c|}
\hline Indicators & total $n=813$ & high risk $n=87$ & medium risk $n=163$ & low risk $n=563$ \\
\hline Age & $55.2 \mathrm{sd} 9.2$ & 64.8 sd 6.3 & $61.2 \mathrm{sd} 7.4$ & 51.9 sd 8.0 \\
\hline $40-49$ & 33.3 & 0 & 6.7 & 46.1 \\
\hline $50-59$ & 30.5 & 11.5 & 21.5 & 36.1 \\
\hline $60-69$ & 27.9 & 55.2 & 54.6 & 16.0 \\
\hline $70-76$ & 8.2 & 33.3 & 17.1 & 1.8 \\
\hline Gender\% male & 48.7 & 48.3 & 55.8 & 46.7 \\
\hline Smoker current and former & 49.2 & 74.7 & 58.9 & 42.5 \\
\hline Pack-years & 8.8 sd 14.9 & $23.1 \mathrm{sd}$ & $12.3 \mathrm{sd} 14.7$ & $5.3 \mathrm{sd} 9.1$ \\
\hline 0 & 52.3 & 25.6 & 41.9 & 59.8 \\
\hline $1-10$ & 17.1 & 12.8 & 13.1 & 19.0 \\
\hline $11-24$ & 18.3 & 23.3 & 25.0 & 15.3 \\
\hline $25-49$ & 12.3 & 38.4 & 20.0 & 5.9 \\
\hline BMI & $26.1 \mathrm{sd} 4.1$ & $24.2 \mathrm{sd} 3.0$ & $25.8 \mathrm{sd} 3.8$ & $26.4 \mathrm{sd} 4.2$ \\
\hline \multicolumn{5}{|l|}{ Symptoms } \\
\hline cough & 18.3 & 34.5 & 25.8 & 13.7 \\
\hline sputum & 13.8 & 23.0 & 20.9 & 10.3 \\
\hline wheeze & 15.7 & 42.5 & 27.0 & 8.3 \\
\hline allergy & 23.4 & 8.0 & 16.6 & 27.7 \\
\hline
\end{tabular}

\section{Impact on resources}

Time aspects and workload in this survey were assessed in a research setting. To translate the findings to routine general practice, we assumed that the screening and measurements would be spread out over one year (40 working weeks, or 200 days). We also assumed that the survey would not be done by a call center, but by the practice receptionist and practice nurse. An average practice in the Netherlands includes 700 persons in the target age group of 40 to 75 years. According to our findings (diagram 2.1), these would include (160/2) 80 persons with a previous diagnosis of asthma or COPD and/or known relevant comorbidity. Hence, 620 persons would have to be contacted, and $60 \%$ of these would provide completed questionnaires, while $60 \%$ would respond to a request for spirometry. 
Table 2.3 Indicators after spirometry and diagnosis.

\begin{tabular}{|c|c|c|c|}
\hline Indicators & $\begin{array}{l}\text { Total } \\
n=149\end{array}$ & $\begin{array}{l}\text { High risk } \\
n=58\end{array}$ & $\begin{array}{l}\text { Medium risk } \\
n=91\end{array}$ \\
\hline \multicolumn{4}{|l|}{ Pulmonary function } \\
\hline $\mathrm{FEV}_{1}$ (\% pred post) & 102.0 sd 17.0 & 100.7 sd 17.7 & 102.7 sd 16.6 \\
\hline FVC (\% pred post) & 107.3 sd 15.8 & 110.1 sd 12.8 & 105.7 sd 17.1 \\
\hline $\mathrm{FEV}_{1} / \mathrm{FVC}$ (post) & 74.6 sd 8.4 & $72.2 \mathrm{sd} 9.3$ & $76.2 \mathrm{sd} 7.4$ \\
\hline FER $<70$ & 24.5 & 39.7 & 14.6 \\
\hline Significant bronchodilation & $4.4 \mathrm{sd} 4.8$ & $4.1 \mathrm{sd} 4.3$ & 4.6 sd 5.1 \\
\hline \multicolumn{4}{|l|}{ Diagnose } \\
\hline normal lung function & 70.6 & 56.9 & 80.0 \\
\hline COPD & 17.5 & 31.0 & 8.2 \\
\hline COPD and asthma & 7.7 & 8.6 & 7.1 \\
\hline asthma & 4.2 & 3.4 & 4.7 \\
\hline \multicolumn{4}{|l|}{ GOLD classification } \\
\hline GOLD I & & $68.2 \%$ & $66.7 \%$ \\
\hline GOLD II & & $31.8 \%$ & $33.3 \%$ \\
\hline
\end{tabular}

\section{Extra time required by the receptionist for the telephone questionnaires}

Since there would be 620 persons to be contacted by phone, and each takes about 6 minutes, the phone calls would require 62 extra receptionist hours. This corresponds to 90 minutes a week, whichmeans 3 additional calls a day. In this scenario, the advantage is that when the receptionist makes the calls, she can identify medium or high risk using the questionnaire and make an appointment for spirometry at the surgery within the same call.

\section{Time required for extra spirometries by the practice nurse}

Sixty percent of the indicated population at risk were willing to complete a symptom questionnaire, corresponding to $(60 \%$ of 620$) 372$ completed questionnaires in an average practice. This would identify (31\%) 115 persons at risk, requiring $(60 \%$ of 115$) 69$ spirometries. Since each spirometry consultation takes 30 minutes, the workload for 69 extra spirometries would be 35 extra practice nurse hours. Spread out over one year (40 wks) this would imply fewer than 2 extra spirometries a week. 


\section{Extra time investment for the GP}

In $25 \%$ of the above-mentioned 69 spirometries, the GP would be involved to finalize the diagnosis of COPD; thismeans 17 additional new (20-minute) COPD consultations in one year, or 6 extra GP consultation hours. Furthermore, the GP would have to invest time to coach the practice nurse during the screening programme. In the first 8-week period this might take 30 minutes each week, and 1 hour every 4 weeks in the remaining 8 months. The total investment would thus be 12 GP coaching hours a year. After calculating this extra time workload in costs in the average Dutch general practice, it became clear that the process of detecting new COPD patients generates more income.

\section{Follow-up on newly established diagnoses}

A new GP appointment was made after each spirometry consultation when a new diagnosis was established. Two persons were referred to a pulmonologist directly after the GP consultation. These 2 later proved to have lung cancer. All persons with COPD were asked to come back for a newpractice nurse consultation, where seven patients failed to show up within 3 months. All smokers were asked to come back for a stop smoking intervention. Six persons with newly found COPD were never smokers, 10 former smokers $(27 \%)$ and 21 smokers $(57 \%)$. Sixteen persons $(43 \%)$ had complaints, while 7 of them did not receive medication. In the 37 persons with newly detected COPD, 11 persons $(30 \%)$ also had an asthma component. Three times during the present survey, doctors and nurses were asked to evaluate the consultations, spirometries and patient compliance. The nurses were very enthusiastic and motivated to do this extra work. No specific additional problems were identified in this survey, compared with the everyday work of the nurses.

\section{Discussion}

This study showed that case finding results in the detection of new, undiagnosed COPD patients in normal general practice. The use of a telephone questionnaires call center was helpful in assessing the risk of COPD by means of a questionnaire and to select medium- and high-risk patients who could be invited for a consultation at the practice surgery (including spirometry). The strength of this study was that the personal approach, that is, asking questions by telephone to all people aged between 40 and $75 \mathrm{yrs}$ registered with a GP practice, led to a very reasonable response rate.

The call center told every respondent that their own doctor had asked them to do this. The personal approach resulted in few incomplete questionnaires, although some people refused to answer. The most probable explanation for this is that 
people were being called by a person from an unknown call center rather than by their own doctor's practice receptionist. Another reason was that many people told the telephone operator that they had no symptoms. They argued that they were not the right person to answer the questions, because they did not feel ill and because they did not smoke. This is a difference with surveys in a different clinical setting, like interviews in waiting rooms, which focus on patients who visit their doctor with a "reason for encounter". Persons with another known disease, or persons in the waiting room, including smokers, are probably more motivated to respond to questionnaire surveys.

The non-response to the receptionist's invitation for spirometry was in all cases due to the inability to reach these persons by telephone during the daytime. Many people in this age bracket work during the day, and of those who were reached by phone, very few refused spirometry.

If practices performed a screening programme all by themselves (without using a call center), we would expect a much higher response, as the receptionist could administer the telephone questionnaires herself, persons at risk could instantly make an appointment for spirometry, the receptionist could spread out her efforts to contact people at risk over one year and could also send a letter in case telephone contact fails, and the spirometries could also be spread out over one year.

We statistically compared the characteristics within the two risk groups between people who did undergo spirometry and those who did not. There were no significant differences, except for a higher average age and more pack-years in the medium-risk group without spirometry, which may have led to an underestimation of obstruction in this group.

What would have been the consequence of this screening in general practices for the prevalence of COPD? Based on the findings of the second Dutch National Survey (27), the 40- to 75-year age group represents $33 \%$ (700 of 2,100 persons) of the total population registered with the general practices in our study. We assume that a maximum of $10 \%(700-70=630)$ of the persons of this group were already known with COPD. According to our data, $31 \%$ are at risk (195 out of 630 ) for COPD. One in 4 of these persons (49 persons) will have the diagnosis of COPD confirmed by spirometry. In an average GP practice, this would mean $119(49+70)$ COPD patients after screening, with $41 \%(49 / 119)$ of all COPD patients not previously detected.

The average prevalence of COPD in Dutch general practices is 3\%. (28) According to our survey, a screening programme would result in the prevalence in average practices rising from $3.3 \%(70 / 2100)$ to $5.7 \%(119 / 2100)$. This implies a considerable effect of our programme in terms of increasing the percentage of COPD cases identified, especially in the earlier stages of the disease. 
Our study was subject to some potential limitations. The burden of effort in this survey in general practice was in the telephone questionnaire, as many persons had to be called in a short time. The cost of engaging a call center for a general practice setting is a large expenditure. We did not offer spirometry to the low-risk group because of the large additional workload; the aim of this study was to detect only patients in the high-and medium-risk groups. The response rate for spirometry among those identified as high- or medium-risk by the questionnaire was rather low: this could be improved by sending those who could not be reached by phone a letter. Patients seem to respond more easily to phone calls by the practice receptionist than by a call center, which may have reduced the response rate. Time and cost restrictions did not seem to be insuperable in this single survey. The method of contacting persons by phone in this survey could be refined.

Patient satisfaction about the questionnaires was not assessed, but after spirometry, all respondents were asked by the practice nurse about their expectations and satisfaction.

Nearly all persons said they appreciated coming to the practice to undergo spirometry. Patients' opinions about their spirometry consultation were nearly always positive. They found it important that doctors and nurses were interested in their health status. Patients appreciated the time that was available for support and advice in response to their questions during the consultation with the nurse. After the spirometry, most people said they wanted to return for further consultations. After spirometry, all smokerswere offered assistance to give up smoking. Smokers with abnormal spirometry values, but also those with normal values, asked for more support to give up smoking. Since many of them had already tried a few times to quit, some did not want to make a new appointment immediately.

A recommendation to other GPs would be to invest greater efforts in detecting COPD patients in the 40-75-year-age group. Since our survey shows many more unknown COPD patients can be detected, the approach should be refeatured in other practices.

\section{Conclusion}

The personal approach of using a telephone questionnaire to detect new COPD cases leads to a high response. The number of undiagnosed COPD patients in the general practice population is considerable. Time aspects do not appear to be an obstacle for starting a practice-led COPD case-finding project in the Netherlands. More research in GP practices should be done to detect regional differences, to assess cost-effectiveness and to focus on an approach involving only the GP's office itself, without external agencies like call centers. 


\section{References}

1. Global Initiative for Chronic Obstructive Lung Disease. Global strategy for the diagnosis, management, and prevention of chronic obstructive pulmonary disease, updated 2010. Available at: www.goldcopd.com. Accessed Aug 31, 2010.

2. RIVM Volksgezondheid Toekomst Verkenning, Nationaal Kompas Volksgezondheid 2003. Bilthoven: RIVM; 2003.

3. Thiadens HA, Bock GH de, Dekker FW, Huysman JAN, Houwelingen JC, van, Springer MP, et al. Identifying asthma and chronic obstructive pulmonary disease in patients with persistent cough presenting to general practitioners: descriptive study. BMJ 1998;316:1286-1290.

4. Tirimanna PR, Schayck CP van, Otter JJ den,Weel C van, Herwaarden CL van, Boom G van den et al. Prevalence of asthma and COPD in general practice in 1992: has it changed since 1977? Br J Gen Pract 1996;46:277-281.

5. Renwick DS, Conolly MJ. Prevalence and treatment of chronic airways obstruction in adults over the age of 45. Thorax 1996;51:164-168.

6. Siafakis NM, Vermeire P, Pride NB, Paoletti P, Gibson J, Howard P, et al. ERS consensus statement. Optimal assessment and management of chronic obstructive pulmonary disease (COPD). Eur Respir J 1995;8:1398-1420.

7. van Weel C. Underdiagnosis of asthma and COPD: is the general practitioner to blame? Monaldi Arch Chest Dis 2002;57:65-68.

8. Schayck CP van, Heijden FMMA van Der, Boom G van den, Tirimanna PRS, van Herwaarden CLA. Underdiagnosis of asthma: is the doctor or the patient to blame? The DIMCA project. Thorax 2000;55:562-565.

9. Fletcher $\mathrm{C}$, Peto $\mathrm{R}$, Tinker $\mathrm{C}$. The natural history of chronic aifflow obstruction. $B M J$ 1977;i:1645-1648.

10. Anthonissen NR, Conett JE, Kiley JP, Altose MD, Bailey WC, Buist AS. Effects of smoking intervention and the use of an inhaled anticholinergic bronchodilator on the rate of decline of $\mathrm{FEV}_{1}$ : the lung health study. JAMA 1995;273:1497-1505.

11. Bednarek M, Gorecka D, Wielgomas J. Smokers with airway obstruction are more likely to quit smoking. Thorax 2006;61:869-873.

12. Gingter $\mathrm{C}$, Wilm $\mathrm{S}$, Abholz $\mathrm{HH}$. Is COPD a rare disease? Prevalence and identification rates in smokers aged 40 years and over within general practice in Germany. Fam Pract 2009;26:3-9.

13. van Der Molen T, Willemse BWM, Schokker S, ten Hacken NHT, Postma DS, Juniper EF. Development, validity and responsiveness of the Clinical COPD Questionnaire. Health Qual Life Out 2003;1:13.

14. van Schayck CP, Halbert RJ, Nordyke RJ, et al. Comparison of existing symptom-based questionnaires for identifying COPD in the general practice setting. Respirology 2005;10: 323-333.

15. van Schayck CP, Loozen JM,Wagena E, et al. Detecting patients at a high risk of developing chronic obstructive pulmonary disease in general practice: cross sectional case finding study. BMJ 2002;324:1370.

16. Vandevoorde J, Verbanck S, Gijssels L, Schuermans D, Devroey D, De Backer J, Kartounian $\mathrm{J}$, VinckenW. Early detection of COPD: A case finding study in general practice. Respir Med 2007;101:525-530.

17. Geijer RMM. Detection of COPD in smokers. Thesis 2006. Julius Center for Health Sciences and Primary Care, University Medical Center, Utrecht, the Netherlands.

18. Stratelis $\mathrm{G}$, Jacobsson P, Molstad S, Zetterstrom O. Early detection of COPD in primary care: screening by invitation of smokers aged 40 to 55 years. Brit J Gen Pract 2004;54:201-206.

19. Piperno D, Bart F, Serrier P, Zureik M, Finkielsztejn L. General practice patients at risk of chronic obstructive pulmonary disease. Presse Medical 2005;34:1617-1622.

20. Price DB, Tinkelman DG, Halbert RJ, et al. Symptom-based questionnaire for identifying COPD in smokers. Respiration 2006;73:285-295. 
21. Price DB, Tinkelman DG, Nordyke RJ, Isonaka S, Halbert RJ; for the COPD Questionnaire Study Group. Scoring system and clinical application of COPD diagnostic questionnaires. Chest 2006;129:1531-1539.

22. Kotz D, Nelemans $P$, Schayck $C P$ van, Wesseling GJ. External validation of a COPD diagnostic questionnaire. Eur Resp J 2008;31:298-303.

23. Calverley PMA, Nordyke RJ, Halbert RJ, et al. Development of a population-based screening questionnaire for COPD. J COPD 2005;2:225-232.

24. Zielinski J, Bednarek M. Early detection of COPD in a highrisk population using spirometric screening. Chest 2001;119:731-736.

25. Boom G van den, Schayck CP van, van Rutten-Mölken MPMH, et al. Active detection of COPD and asthma in the general population: results and economic consequences of the DIMCA programme. Am J Resp Crit Care Med 1998;158:1730-1738.

26. Schayck van $\mathrm{CP}$, Chavannes $\mathrm{NH}$. Detection of asthma and chronic obstructive pulmonary disease in primary care. Eur Resp J 2003;21(Suppl 39): 16S-22S.

27. Linden MWvan Der,Westert GP, Bakker DH de, Schellevis FG. Second National Study, 2004, NIVEL, Utrecht.

28. Tabak C, Smit HA. De morbiditeit van astma en COPD in Nederland; leemtes in kennis opgevuld door aanvullende analyses en actualisering van beschikbare gegevensbronnen (RIVM-rapport 260855005/2002). Bilthoven: RIVM; 2002. 

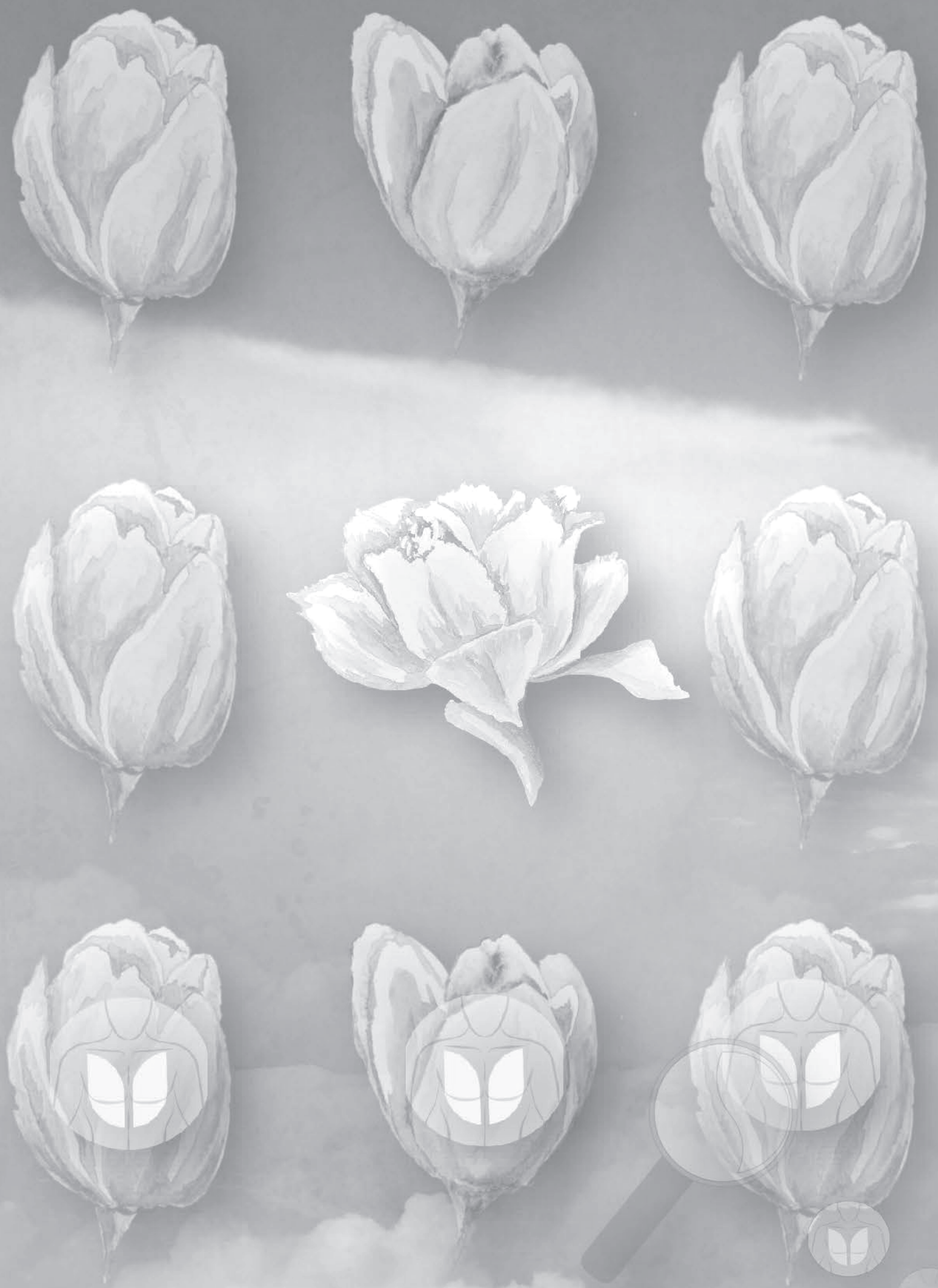


\section{Chapter 3

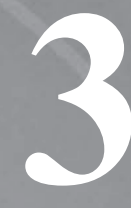

Early detection of COPD in general practice: patient or practice managed? A randomised controlled trial of two strategies in different socioeconomic environments

J.A.M. Dirven, H.J. Tange, J.W.M. Muris, K.M.A. van Haaren, G. Vink, O.C.P. van Schayck.

Primary Care Respiratory Journal 2013;22:331-337 


\section{Abstract}

\section{Background}

The burden of chronic obstructive pulmonary disease (COPD) is high. Health benefits can be gained in primary care by early detection and preventive measures.

\section{Aims}

To compare the effectiveness of two strategies for population-based early detection of COPD, taking into account different socioeconomic status (SES) settings.

\section{Methods}

Practices were randomised on strategy and stratified on SES setting. The Respiratory Health Screening Questionnaire (RHSQ) was distributed to all participants. In the practice-managed condition, the practice was responsible for the whole procedure, while in the patient-managed condition, patients were responsible for calculating their RHSQ risk score and applying for a spirometry test. The main outcome measure was the rate of COPD diagnoses after screening.

\section{Results}

More new COPD patients were detected in the practice-managed condition $(36 \%)$ than in the patient-managed condition (18\%). In low SES practices, more high-risk patients were found $(16 \%)$ than in moderate-to-high SES practices (9\%). Recalculated for a standard Dutch practice (2,350 patients), the yield would be 8.9 new COPD diagnoses, which is a $20 \%$ increase of known cases.

\section{Conclusions}

The practice-managed variant of this screening procedure shows a substantial yield of new COPD diagnoses for both low and moderate-to-high SES practices. 


\section{Introduction}

Chronic obstructive pulmonary disease (COPD) is one of the most prevalent causes of morbidity and mortality worldwide. It represents the largest fraction of mortality for respiratory diseases, which form the third most common cause of death in the European Union (8\%). (1-5) The worldwide prevalence of COPD in the general population is rising steeply to $10 \%$ among those aged 40 years or more. (6-8) The prevalence of detected COPD in Dutch general practices is $2 \%$. (9) In many western countries, another $2 \%$ of COPD remains undiagnosed. (10) Miravitlles et al. found that only $60 \%$ of people with chronic respiratory symptoms consulted a physician and only $45 \%$ of them underwent spirometry. (11) Our research showed that high-risk patients detected by screening reported having had respiratory symptoms previously without seeking help. (12) Smokers are particularly unaware of having symptoms and neglecting to see a doctor. They feel shame and guilt because of a self-inflicted disease associated with persistent smoking habits(13) and they adapt to slowly developing respiratory problems. (14)

Cigarette smoking is the main causal factor of COPD in the western world and is also the most important risk factor that can be influenced. $(15,16)$ Starting age, total pack-years, and current smoking status are all predictors of COPD mortality. (17) Definitive smoking cessation makes sense at any stage of the disease and slows the decline of forced expiratory volume in one second $\left(\mathrm{FEV}_{1}\right)$ from $60 \mathrm{ml} /$ year to $30 \mathrm{ml} /$ year. (18) Even temporary cessation helps to slow the decline.19 The success of smoking cessation is greater when people participate in a prevention programme that includes spirometry. (20)

Low socioeconomic status (SES) is also an important risk factor for COPD. It correlates significantly with lower lung function, even after adjustment for smoking status, occupational exposures, and race or ethnic origin. (21) The impact of low SES on lung function is variable, but $\mathrm{FEV}_{1}$ reductions of $>300 \mathrm{ml}$ in men and $>200 \mathrm{ml}$ in women have been reported. (22) Non-smokers with low SES can be seen as independent groups at risk of COPD. (23)

A third risk factor for COPD - independent of SES and smoking - is poor health literacy. It is associated with more severe COPD stages, greater COPD helplessness, worse respiratory-related quality of life, and more use of COPDrelated emergency healthcare. (24)

Early detection programmes combined with smoking cessation interventions may delay the progression of COPD. (25) The literature reveals several COPD case-finding initiatives among patients in waiting rooms, patients with comorbidities, (26-31) and among smokers, (32-34) but only a few populationbased screening studies of COPD. (12,35-37) All these studies report 13-41\% additional COPD diagnoses. 
The Respiratory Health Screening Questionnaire (RHSQ) is a population-based questionnaire for early COPD detection in a random population, and it includes a validated set of questions and a score card system (Table 3.1). $(38,39)$ The RHSQ was piloted in a Dutch general practice population in 2008 and found $11 \%$ of the respondents to be at high risk. After post-bronchodilator spirometry, $39.6 \%$ of these high-risk respondents were diagnosed with COPD. (12)

These results prompted us to evaluate this combination of questionnaire and spirometry on a larger scale. Anticipating a possible nationwide rollout of the RHSQ, we had to take into account the consequences of extra workload for family practices. A standard Dutch practice has 2,350 patients, including 700 in the target group for the RHSQ (age 40-70 years). It was estimated that conducting the RHSQ would take about 10 hours per standard practice (half for preparation, half for settlement). We therefore tested two strategies: one in which the practice is responsible for the whole procedure and another in which the practice is responsible for only the recruitment and the respondent is responsible for handling the RHSQ and requesting a spirometric test when indicated.

The aim of this study was to determine the yield of a population-based early detection procedure including (a) risk screening by the RHSQ and (b) spirometric testing of high-risk patients in primary care. Our research questions were:

- How many new COPD diagnoses are found by this procedure?

- Is there a difference between a practice-managed and a patient-managed strategy?

- How does the SES profile of the practice influence the effectiveness of these strategies?

\section{Methods}

\section{Setting and design}

We conducted a cluster randomised controlled trial among 16 family practices of different sizes from May to September 2012. The practices were located in four cities in the middle and south of the Netherlands. The RHSQ was sent to all eligible patients registered with these practices. In the patient-managed condition, patients were responsible for calculating their RHSQ scores and for demanding a spirometry test in case of a high-risk score. In the practicemanaged condition the family practice was responsible for the whole process.

Practices were stratified based on socioeconomic status (SES). There is no universally accepted definition of SES, and stratification criteria vary from 
occupation, educational level, income, and residential area.40 We took the criterion of residential area based on the Dutch Health Authority public register. In this register practices are classified as low SES or moderate to high SES depending on the socioeconomic profile of their adhering area (based on postal codes).

\section{Population}

People aged 40-70 years, excluding those already diagnosed with asthma or COPD or with other serious lung diseases such as lung cancer, pneumoconiosis, tuberculosis, bronchiectasis, and pneumonectomy, were eligible to take part in the study. People using oxygen supplementation and those with impaired mobility were also excluded. Ethical approval was obtained from Medical Ethics Review Board (MERB), Atrium Hospital, Heerlen (MERB number 12N33).

\section{Intervention}

The RHSQ is a validated questionnaire for screening patients at risk of COPD (Table 3.1). $(38,39)$ It was posted to patients and responders had the opportunity of mailing or emailing by log-in code. It contains 10 simple questions about age, smoking history, body weight, body length, and respiratory complaints (Table 3.1). The standard version includes a scoring card to calculate the risk of COPD: low risk (<16.5 points), medium risk (16.5-19.5 points), or high risk ( $>19.5$ points).

People in the patient-managed condition used this scoring card to calculate their risk themselves; the scoring card advised them to consult the family practitioner in case of a high-risk score. In the practice-managed condition the scoring card was removed and risks were calculated by the family practice; people with a high-risk score were explicitly invited for a spirometry test.

The spirometry test was conducted according to the prevailing guidelines of the Dutch College of General Practitioners. (41) A COPD diagnosis was based on the combination of a post-bronchodilator $F E V_{1} / F V C$ ratio $<0.7$ and the physician's clinical evaluation. (42) All participants gave informed consent.

\section{Outcome measures}

The main outcome measure was the number of new COPD diagnoses after spirometry per practice. Secondary outcome measures were the rate of RHSQ high-risk scores and the yield of new COPD diagnoses in a standard Dutch practice (2,350 patients). Determinants were the intervention strategy, the SES 
profile of the practice, the smoking status of the patient, and the practice prevalence of COPD prior to the screening.

Table 3.1 Respiratory Health Screening Questionnaire (RHSQ) score card.

\begin{tabular}{|c|c|c|c|}
\hline \multicolumn{2}{|c|}{ Question } & \multirow{2}{*}{$\begin{array}{l}\text { Answer } \\
40-49\end{array}$} & \multirow{2}{*}{$\frac{\text { Score }}{0}$} \\
\hline 1. & What is your age? & & \\
\hline & Age group, years & $50-59$ & 4 \\
\hline & & $60-69$ & 8 \\
\hline $2(a)$ & How many cigarettes have you smoked per day? & ....... cigarettes & \\
\hline \multirow[t]{2}{*}{ 2(b) } & Are you smoking now? & Yes $\mathrm{O}$ & \\
\hline & & No $\mathrm{O}$ & \\
\hline $3(a)$ & How many years have you smoked? & ........ years & \\
\hline \multirow[t]{4}{*}{$3(b)$} & Pack years I have smoked & $0-14$ & 0 \\
\hline & & $15-24$ & 2 \\
\hline & & $25-49$ & 3 \\
\hline & & $50+$ & 7 \\
\hline 4. & What is your weight? & $\ldots \ldots \ldots \mathrm{kg}$ & \\
\hline \multirow[t]{4}{*}{5.} & What is your height? & ........m $\mathrm{m}$ & \\
\hline & Body mass index, $\mathrm{kg} / \mathrm{m}^{2}$ & $>29.7$ & 0 \\
\hline & & $25.4-29.7$ & 1 \\
\hline & & $<25.4$ & 5 \\
\hline \multirow[t]{3}{*}{6.} & Does the weather affect your cough? & Yes & 3 \\
\hline & & No & 0 \\
\hline & & Do not cough & 0 \\
\hline \multirow[t]{2}{*}{7.} & Do you have phlegm without a cold? & Yes & 3 \\
\hline & & No & 0 \\
\hline \multirow[t]{2}{*}{8.} & Do you have phlegm in the morning? & Yes & 0 \\
\hline & & No & 3 \\
\hline \multirow[t]{2}{*}{9.} & Do you wheeze (frequency)? & Never & 0 \\
\hline & & Sometimes or often & 4 \\
\hline \multirow[t]{2}{*}{10.} & Have or had any allergies? & Yes & 0 \\
\hline & & No & 3 \\
\hline
\end{tabular}

\section{Data sampling and analysis}

Data from questionnaires and spirometry tests were collected in a central database and completed with interview data about smoking status. To get insight into the reasons for non-response, a sample of 10 non-responders per practice were approached by telephone with one open question - their reason for non-participation. 
Descriptive and testing statistics were calculated by SPSS-19. Differences between groups were assessed by $\chi^{2}$ tests after correction for cluster randomisation and stratification by logistic regression. Correlation between prior prevalence and percentage of newly detected COPD was evaluated by Pearson's correlation test.

\section{Results}

\section{Response and demographics}

The enrolled practices included 11,498 patients aged 40-70 years. A total of 1,390 patients (597 with a known COPD diagnosis) met one or more of the exclusion criteria. The RHSQ was distributed in the enrolled practices to 10,108 people and a total of 3,573 responded. The response to the questionnaire was $50 \%$ in the practice-managed condition (52\% low SES, $47 \%$ moderate to high SES) and $27 \%$ in the patient-managed condition (24\% low SES, $29 \%$ moderate to high SES). Table 3.2 shows that both conditions were similar with respect to age and gender, but not for smoking behaviour. The patient-managed condition yielded fewer smokers, which suggests a response bias on smoking behaviour in favour of non-smokers. Table 3.3 shows that respondents in low SES practices were on average older, more often current smokers, and had more pack-years than respondents in moderate to high SES practices.

Table 3.2 Characteristics of respondents by trial condition.

\begin{tabular}{lcccc}
\hline & Total & $\begin{array}{c}\text { Patient } \\
\text { Managed }\end{array}$ & $\begin{array}{c}\text { Practice } \\
\text { managed }\end{array}$ & p Value \\
\hline & $(\mathrm{n}=3,573)$ & $(\mathrm{n}=1,717)$ & $(\mathrm{n}=1,856)$ & \\
Mean (SD) age* & $53.6(8.5)$ & $53.5(8.4)$ & $53.7(8.5)$ & 0.319 \\
Male** $_{\text {Smoking status }}^{* *}$ & $1,797(50.3 \%)$ & $875(51.0 \%)$ & $922(49.7 \%)$ & 0.466 \\
$\quad$ & & & & \\
Never & $1,608(45 \%)$ & $827(48 \%)$ & $777(42 \%)$ & \\
Former & $458(13 \%)$ & $197(12 \%)$ & $261(14 \%)$ & 0.000 \\
$\quad \begin{array}{l}\text { Current } \\
\text { Pack years } \\
\text { (median, min-max })\end{array}$ & $1,505(42 \%)$ & $688(40 \%)$ & $817(44 \%)$ & 0.000 \\
\hline
\end{tabular}

${ }^{*}$ Chi-square test. ${ }^{* *}$ Student $t$ test. ${ }^{* * *}$ Mann-Whitney $U$ test (pack years $=0$ excluded). 
The attendance for spirometry among high-risk respondents was $54 \%$ in the practice-managed condition (49\% low SES, $64 \%$ moderate to high SES) and $75 \%$ in the patient-managed condition (78\% low SES, $73 \%$ moderate to high SES). Reasons for nonparticipation in low SES practices were lack of time, other health problems, no understanding, and no risk awareness while, in moderate to high SES practices, reasons for non-participation were no complaints, forgotten, lack of time, and no interest.

Table 3.3 Characteristics of respondents by socioeconomic status (SES).

\begin{tabular}{lcccc}
\hline & Total & Low SES & Average SES & $p$ Value \\
\hline & $(\mathrm{n}=3,573)$ & $(\mathrm{n}=1,613)$ & $(\mathrm{n}=1,960)$ & \\
Mean (SD) age* $^{*}$ & $53.6(8.5)$ & $54.4(8.8)$ & $52.9(8.2)$ & 0.000 \\
Male** $_{\text {Smoking status }}^{* *}$ & $1,797(50.3 \%)$ & $821(51.0 \%)$ & $976(49.8 \%)$ & 0.488 \\
$\quad$ & & & & \\
Never & $1,608(45 \%)$ & $699(43 \%)$ & $905(46 \%)$ & \\
Former & $458(13 \%)$ & $185(12 \%)$ & $273(14 \%)$ & \\
$\begin{array}{l}\text { Pack yearrent } \\
\text { (median, min-max) }\end{array}$ & $1,505(42 \%)$ & $725(45 \%)$ & $780(40 \%)$ & 0.003 \\
\hline
\end{tabular}

${ }^{*}$ Chi-square test. ${ }^{* *}$ Student $t$ test. ${ }^{* \star *}$ Mann-Whitney $U$ test (pack years $=0$ excluded).

\section{Test outcomes}

Table 3.4 shows that there was no significant difference in the rate of high-risk scores between respondents in the two conditions, which does not reveal evidence for a response bias based on the risk test score. In the practicemanaged condition, however, high-risk respondents had more COPD than in the patient-managed condition ( $36 \%$ vs. $18 \%, p<0.05)$. This difference was even larger among active smokers ( $54 \%$ vs. $25 \%$ ).

Low SES practices had significantly more high-risk respondents than moderate to high SES practices $(16 \%$ vs. $9 \%, p<0.05)$. However, there was no significant difference between the two groups with respect to the chance of having COPD. On the practice level, there was no correlation between the prior prevalence of COPD and the percentage of newly detected COPD diagnoses (Pearson's coefficient -0.167 ).

The yield of our screening procedure for early detection was 73 new COPD diagnoses out of 10,108 participants for both strategies, giving an average of 8.9 new COPD diagnoses per standard Dutch practice in the practice-managed condition and 3.0 in the patient-managed condition. Thus, the practice-managed 
approach was approximately three times as effective as the patient-managed approach.

Table 3.4 Results of the RHSQ and spirometry test by strategy and socioeconomic status (SES).

\begin{tabular}{|c|c|c|c|}
\hline Results (by SES setting) & $\begin{array}{c}\text { All } \\
\text { strategies }\end{array}$ & $\begin{array}{l}\text { Patient- } \\
\text { managed } \\
\text { strategy }\end{array}$ & $\begin{array}{l}\text { Practice- } \\
\text { managed } \\
\text { strategy }\end{array}$ \\
\hline \multicolumn{4}{|l|}{ All practices } \\
\hline RHSQs distributed & 10,108 & 6,393 & 3,715 \\
\hline Responders (\% of distributed) & $3,570(35 \%)$ & $1,715(27 \%)$ & $1,855(50 \%)$ \\
\hline High risk on RHSQ (\% of responders) & $437(12 \%)$ & $186(11 \%)$ & $251(14 \%)$ \\
\hline Show up for spirometry (\% of high risk) & $275(63 \%)$ & $140(75 \%)$ & $135(54 \%)$ \\
\hline COPD diagnosis (\% of show up) & $73(27 \%)$ & $25(18 \%)^{\dagger}$ & $48(36 \%)^{\dagger}$ \\
\hline Smokers among show up (\% of show up) & $129(47 \%)$ & $53(38 \%)$ & $76(56 \%)$ \\
\hline COPD diagnosis among smokers ( $\%$ of show up) & $54(42 \%)$ & $13(25 \%)$ & $41(54 \%)$ \\
\hline COPD diagnoses in a standard practice* & 5.3 & 3.0 & 8.9 \\
\hline \multicolumn{4}{|l|}{ Low SES practice } \\
\hline RHSQs distributed & 4,422 & 2,476 & 1,946 \\
\hline Responders (\% of distributed) & $1,613(36 \%)$ & $598(24 \%)$ & $1,015(52 \%)$ \\
\hline High risk on RHSQ (\% of responders) & $252(16 \%)^{\ddagger}$ & $86(14 \%)$ & $166(16 \%)$ \\
\hline Show up for spirometry (\% of high risk) & $148(59 \%)$ & $67(78 \%)$ & $81(49 \%)$ \\
\hline COPD diagnosis (\% of show up) & $46(31 \%)$ & $14(21 \%)$ & $32(40 \%)$ \\
\hline Smokers among show up (\% of show up) & $78(53 \%)$ & $29(43 \%)$ & $49(60 \%)$ \\
\hline COPD diagnosis among smokers ( $\%$ of show up) & $35(45 \%)$ & $8(28 \%)$ & $27(55 \%)$ \\
\hline \multicolumn{4}{|l|}{ Moderate to high SES practice } \\
\hline RHSQs distributed & 5,686 & 3,917 & 1,769 \\
\hline Responders (\% of distributed) & $1,957(34 \%)$ & $1,117(29 \%)$ & $840(47 \%)$ \\
\hline High risk on RHSQ (\% of responders) & $185(9 \%)^{\ddagger}$ & $100(9 \%)$ & $85(10 \%)$ \\
\hline Show up for spirometry (\% of high risk) & $127(69 \%)$ & $73(73 \%)$ & $54(64 \%)$ \\
\hline COPD diagnosis (\% of show up) & $27(21 \%)$ & $11(15 \%)$ & $16(30 \%)$ \\
\hline Smokers among show up (\% of show up) & $51(40 \%)$ & $24(33 \%)$ & $27(50 \%)$ \\
\hline COPD diagnosis among smokers (\% of show up) & $19(37 \%)$ & $5(21 \%)$ & $14(52 \%)$ \\
\hline
\end{tabular}

${ }^{*}$ Extrapolation for a standard Dutch practice including 2,350 patients. ${ }^{\dagger} \mathrm{A}$ pro-active approach results in more positive spirometry than a re-active approach $(p<0.01)$. ${ }^{\ddagger}$ Low SES practices have more highrisk scores on the RHSQ than moderate to high SES practices $(p<0.001)$. RHSQ=Respiratory Health Screening Questionnaire. 


\section{Cost per detected case}

Table 3.5 shows that, for a standard Dutch practice, 77 RHSQs had to be distributed (61 low SES, 111 moderate to high SES), three spirometry tests had to be performed (in both SES settings) and, additionally, one COPD consultation had to be undertaken to detect one new COPD diagnosis in the practicemanaged condition. The total cost of the detection programme was $€ 256$ per detected case ( $€ 224$ low SES, $€ 324$ moderate to high SES). In the patientmanaged condition, 256 RHSQs had to be distributed and six spirometry tests had to be performed, with a cost of $€ 698$ per detected case.

Table 3.5 Number of start conditions needed to detect one COPD diagnosis in a standard Dutch practice (2350 patients).

\begin{tabular}{lcc}
\hline Start condition (by SES setting) & Patient managed & Practice managed \\
\hline All practices & 256 & 77 \\
RHSQs distributed & 6 & 3 \\
Responders for spirometry (all high-risk) & $€ 698$ & $€ 256$ \\
Cost per detected case (all high-risk) & $€ 642$ & $€ 228$ \\
Cost per detected case (high-risk smokers) & & \\
Low SES practices & 177 & 61 \\
RHSQs distributed & 5 & 3 \\
Responders for spirometry (all high-risk) & $€ 512$ & $€ 224$ \\
Cost per detected case (all high-risk) & $€ 484$ & $€ 196$ \\
Cost per detected case (high-risk smokers) & & \\
Moderate to high SES practices & 356 & 111 \\
RHSQs distributed & 7 & 3 \\
Responders for spirometry (all high-risk) & $€ 926$ & $€ 324$ \\
Cost per detected case (all high-risk) & $€ 870$ & $€ 296$ \\
Cost per detected case (high-risk smokers) & & \\
\hline
\end{tabular}

Cost per unit: $€ 2$ for a RHSQ, $€ 28$ for a spirometry test (in case of high risk) and $€ 18$ for a COPD consultation (in case of a positive diagnosis). RHSQ=Respiratory Health Screening Questionnaire, SES=socioeconomic status

\section{Discussion}

\section{Main findings}

Our study has shown that the use of the RHSQ among all those aged 40-70 years followed by spirometry testing of high-risk scoring respondents is effective and can best be provided following a practice-managed strategy. A 
greater responsibility for the patient in this procedure appeared less effective, especially for smokers. We found a return of 8.9 newly detected COPD cases per standard primary care practice, which is an increase of $20 \%$ over the known prevalence. An investment of $€ 224-324$ per detected case seems reasonable for a disease where health benefits can be gained with early detection, since the earlier COPD is detected and behaviour changes are induced, the slower the decline in $\mathrm{FEV}_{1}$ and the better the quality of life prognosis will be, (22) especially among smokers (18) and low SES groups. (43)

\section{Interpretation of findings in relation to previously published work}

Most newly detected COPD patients in our study were active smokers. This indicates room for improvement, because smoking cessation is still the most effective way to reduce the progression of COPD and to improve survival in COPD patients. Some studies have shown that smokers who know that they have COPD are more successful quitters, $(20,44)$ although this observation is not consistent in the literature.

The RHSQ has previously been used only for targeted screening studies among active smokers: Kotz et al. (33) found 41\% COPD after screening, Price et al. (34) found $19 \%$, and Freeman et al. (32) reported $17 \%$. To our knowledge, this is the first study where the RHSQ has been used for population-based screening. In its most effective condition (practice-managed), the yield of COPD after screening was $36 \%$ among high-risk respondents. This is more than population-based screening studies using different questionnaires: Van Schayck et al. (37) reported 18\% COPD after screening and Calverley et al. (35) reported $13 \%$. Only Martinez et al. (36) reported a higher yield of COPD after screening (38\%), but their study recruited also from specialist sources.

The possibility that the RHSQ would be less effective in low SES practices because of an expected lower response is not supported by our results. There was no response bias; the RHSQ returned more high-risk persons and more COPD patients after screening in low SES practices than in moderate to high SES practices. The latter finding is in line with the literature, which reports more COPD among low SES groups. (21)

The assumption that a higher prior prevalence of COPD in a specific practice would leave less room for the detection of new COPD patients is not supported by our study. Furthermore, the apparent under diagnosis of COPD is illustrated by the relatively low proportion of mild COPD in the Netherlands; of all known COPD cases, $28 \%$ have mild disease, $54 \%$ have moderate disease, $15 \%$ have severe disease, and $3 \%$ have very severe COPD. (45) This raises the question of how the potential of undetected COPD can be estimated. The Dutch College of General Practitioners (NHG) estimates the prevalence of known COPD cases at $20 / 1,000$, which means that a standard family practice $(2,350)$ has 47 cases 
of COPD. (41) Soriano et al. estimate that there is another $2 \%$ of undetected COPD patients, which makes the potential prevalence of known and unknown COPD cases $4 \%$. (10) In our most effective strategy (practice-managed) we detected an average of 8.9 new COPD patients per standard Dutch practice. Together with the 47 cases already known, this amounts to 56 COPD cases per family practice, which is $2.4 \%$ of the total population, far less than the $4 \%$ estimated by Soriano et al. This makes it worthwhile to improve further the response of our early detection procedure.

\section{Strengths and limitations of this study}

Although the $50 \%$ response to the questionnaire is acceptable, the $54 \%$ response to the invitation for spirometry is rather low and needs improvement. One way to improve the response is to conduct the intervention in another season. Our study period included the summer holidays, a time when many people are on vacation, especially in low SES practices when many ethnic Mediterranean people leave for a long visit to their native country. Many candidates for the RHQS may have missed the invitation.

A practical limitation of our study is the fact that the whole intervention was performed under time pressure with the help of external practice nurses and supplementary administrative support. For the personnel of a primary care practice it is impossible to screen and test all patients aged $40-70$ years within a period of three months. Without external practice nurse support, it would be more feasible to spread out the effort over a longer time - for example, 15 or 30 months with every month one- or two-year cohorts. We performed a feasibility study for this implementation strategy in 10 other practices and report the results of this study in this same issue of the PCRJ. (46)

\section{Implications for future research, policy and practice}

Future research should focus on the implementation of early diagnosis and treatment of COPD in general practice. Especially important is a full costeffectiveness study investigating early detection of COPD in combination with smoking cessation. 


\section{Conclusions}

A population-based COPD screening procedure among those aged $>40$ years with the RHSQ and spirometry is an effective method for the early detection of COPD in primary care. The yield is higher in low SES practices than in moderate to high SES practices. Regardless of SES, this procedure should preferably be managed by the family practice and not by the patients themselves. 


\section{References}

1. Lopez AD, Mathers CD, Ezzati M, Jamison DT, Murray CJL. Global and regional burden of disease and risk factors, 2001: systematic analysis of population health data. Lancet 2006;367:1747-1757.

2. Lopez AD, Shibuya K, Rao C, et al. The global burden of COPD: future COPD projections. Eur Respir J 2006;27:397-412.

3. Mathers CD, Roncar D. Projections of global mortality and burden of disease from 2002 to 2030. PLoS Med 2006;3:2011-2030.

4. Murray CJ, Lopez AD. Alternative projections of mortality and disability by cause 1990-2020: Global Burden of Disease Study. Lancet 1997;349:1498-1504.

5. Murray CJL, Lopez AD, Black R, et al. Global burden of disease 2005: call for collaborators. Lancet 2007;370:109-110.

6. Buist AS, McBurnie MA, Vollmer WM, et al. International variation in the prevalence of COPD (the BOLD Study): a population-based prevalence study. Lancet 2007;370:741-750.

7. Halbert RJ, Natoli JL, Gano A, Badamgarav E, Buist AS, Mannino DM. Global burden of COPD: systematic review and meta-analysis. Eur Respir J 2006;28:523-532.

8. Menezes AMB, Perez-Padilla R, Jardim JRB, et al. Chronic obstructive pulmonary disease in five Latin American cities (the PLATINO study): a prevalence study. Lancet 2005;366: 1875-1881.

9. van den Berg MJ, Kolthof ED, de Bakker DH, van der Zee J. Tweede Nationale Studie naar ziekten en verrichtingen in de huisartspraktijk - de werkbelasting van huisartsen. [Second National Study to diseases and interventions in primary care - the workload of general practitioners]. Utrecht, The Netherlands: Nivel, 2004.

10. Soriano JB, Zielinski J, Price D. Screening for and early detection of chronic obstructive pulmonary disease. Lancet 2009;374:721-732.

11. Miravitlles M, de la Roza C, Morera J, et al. Chronic respiratory symptoms, spirometry and knowledge of COPD among general population. Respir Med 2006;100:1973-1980

12. Dirven JA, Muris JW, van Schayck CP. COPD screening in general practice using a telephone questionnaire. COPD 2010;7:352-359.

13. Halding A-G, Heggdal K, Wahl A. Experiences of self-blame and stigmatisation for self-infliction among individuals living with COPD. Scand J Caring Sci 2011;25:100-107.

14. van den Boom G, Rutten-van Molken MP, Tirimanna PR, van Schayck $C P$, Folgering $H$, van Weel C. Association between health-related quality of life and consultation for respiratory symptoms: results from the DIMCA programme. Eur Respir J 1998;11:67-72.

15. Bize R, Burnand B, Mueller $Y$, Rege Walther M, Cornuz J. Biomedical risk assessment as an aid for smoking cessation. Cochrane Database Syst Rev 2009;(2):CD004705.

16. Rabe KF, Hurd S, Anzueto A, et al. Global strategy for the diagnosis, management, and prevention of chronic obstructive pulmonary disease: GOLD executive summary. Am J Respir Crit Care Med 2007;176:532-555.

17. Doll R, Peto R, Boreham J, Sutherland I. Mortality in relation to smoking: 50 years' observations on male British doctors. BMJ 2004;328:1519.

18. Scanlon PD, Connett JE, Waller LA, Altose MD, Bailey WC, Buist AS. Smoking cessation and lung function in mild-to-moderate chronic obstructive pulmonary disease. The Lung Health Study. Am J Respir Crit Care Med 2000;161:381-90.

19. Murray RP, Anthonisen NR, Connett JE, et al. Effects of multiple attempts to quit smoking and relapses to smoking on pulmonary function. Lung Health Study Research Group. J Clin Epidemiol 1998;51:1317-1326.

20. Bednarek M, Gorecka D, Wielgomas J, et al. Smokers with airway obstruction are more likely to quit smoking. Thorax 2006;61:869-873.

21. Hegewald MJ, Crapo RO. Socioeconomic status and lung function. Chest 2007;132: 1608-1614. 
22. Prescott E, Lange $\mathrm{P}$, Vestbo J. Socioeconomic status, lung function and admission to hospital for COPD: results from the Copenhagen City Heart Study. Eur Respir J 1999;13:1109-1114.

23. Salvi SS, Barnes PJ. Chronic obstructive pulmonary disease in non-smokers. Lancet 2009;374:733-743.

24. Omachi TA, Sarkar U, Yelin EH, Blanc PD, Katz PP. Lower health literacy is associated with poorer health status and outcomes in chronic obstructive pulmonary disease. J Gen Intern Med 2013;28:74-81.

25. Van Schayck CP, Loozen JMC, Wagena E, Akkermans RP, Wesseling GJ. Detecting patients at a high risk of developing chronic obstructive pulmonary disease in general practice: cross sectional case finding study. BMJ 2002;324:1370.

26. Buffels J, Degryse J, Liistro G. Diagnostic certainty, co-morbidity and medication in a primary care population with presumed airway obstruction: the DIDASCO2 study. Prim Care Respir J 2009;18:34-40.

27. Geijer RMM. Detection of COPD in smokers (Thesis). Utrecht, The Netherlands: Utrecht Medical Center, 2006.

28. Gingter C, Wilm S, Abholz H-H. Is COPD a rare disease? Prevalence and identification rates in smokers aged 40 years and over within general practice in Germany. Fam Pract 2009;26:3-9.

29. Piperno D, Bart F, Serrier P, Zureik M, Finkielsztejn L. [General practice patients at risk of chronic obstructive pulmonary disease: epidemiologic survey of 3411 patients]. Presse Med 2005;34:1617-1622.

30. Stratelis $\mathrm{G}$, Jakobsson $\mathrm{P}$, Molstad $\mathrm{S}$, Zetterstrom $\mathrm{O}$. Early detection of COPD in primary care: screening by invitation of smokers aged 40 to 55 years. Br J Gen Pract 2004;54:201-206.

31. Vandevoorde J, Verbanck S, Gijssels L, et al. Early detection of COPD: a case finding study in general practice. Respir Med 2007;101:525-530.

32. Freeman D, Nordyke RJ, Isonaka S, et al. Questions for COPD diagnostic screening in a primary care setting. Respir Med 2005;99:1311-1318.

33. Kotz D, Nelemans P, van Schayck CP, Wesseling GJ. External validation of a COPD diagnostic questionnaire. Eur Respir J 2008;31:298-303.

34. Price DB, Tinkelman DG, Halbert RJ, et al. Symptom-based questionnaire for identifying COPD in smokers. Respiration 2006;73:285-295.

35. Calverley PM, Nordyke RJ, Halbert RJ, Isonaka S, Nonikov D. Development of a populationbased screening questionnaire for COPD. COPD 2005;2:225-322.

36. Martinez FJ, Raczek AE, Seifer FD, et al. Development and initial validation of a selfscored COPD Population Screener Questionnaire (COPD-PS). COPD 2008;5:85-95.

37. van Schayck CP, Loozen JM,Wagena E, et al. Detecting patients at a high risk of developing chronic obstructive pulmonary disease in general practice: cross sectional case finding study. BMJ 2002;324:1370.

38. Price DB, Tinkelman DG, Nordyke RJ, Isonaka S, Halbert RJ. Scoring system and clinical application of COPD diagnostic questionnaires. Chest 2006;129:1531-1539.

39. van Schayck CP, Halbert RJ, Nordyke RJ, Isonaka S, Maroni J, Nonikov D. Comparison of existing symptom-based questionnaires for identifying COPD in the general practice setting. Respirology 2005;10:323-333.

40. Lynch J, Kaplan G. Socioeconomic position. In: Berkman LK, Kawachi I, editors. Social epidemiology. New York: Oxford University Press, 2000:13-35.

41. Smeele IJ, van Weel C, van Schayck CP, et al. NHG-Standaard COPD [NHG Guideline COPD]. Huisarts Wet 2007;50:362-379.

42. Global Initiative for Chronic Obstructive Lung Disease (GOLD). Global strategy for diagnosis, management, and prevention of COPD update 2009 (cited Feb 2011). Available from: www.goldcopd.com

43. Eisner MD, Blanc PD, Omachi TA, et al. Socioeconomic status, race, and COPD health outcomes. J Epidemiol Community Health 2011;65:26-34.

44. Parkes G, Greenhalgh T, Griffin M, Dent R. Effect on smoking quit rate of telling patients their lung age: the Step2quit randomised controlled trial. BMJ 2008;336:598-600. 
45. Hoogendoorn M, Rutten-van Molken MPMH, Hoogenveen RT, et al. A dynamic population model of disease progression in COPD. Eur Respir J 2005;26:223-233.

46. Dirven JAM, Tange JT, Muris JWM, van Haaren KMA, Vink G, van Schayck CP. Early detection of COPD in general practice - implementation, workload and socioeconomic status: an observational study. Prim Care Respir J 2013;22:338-343. 

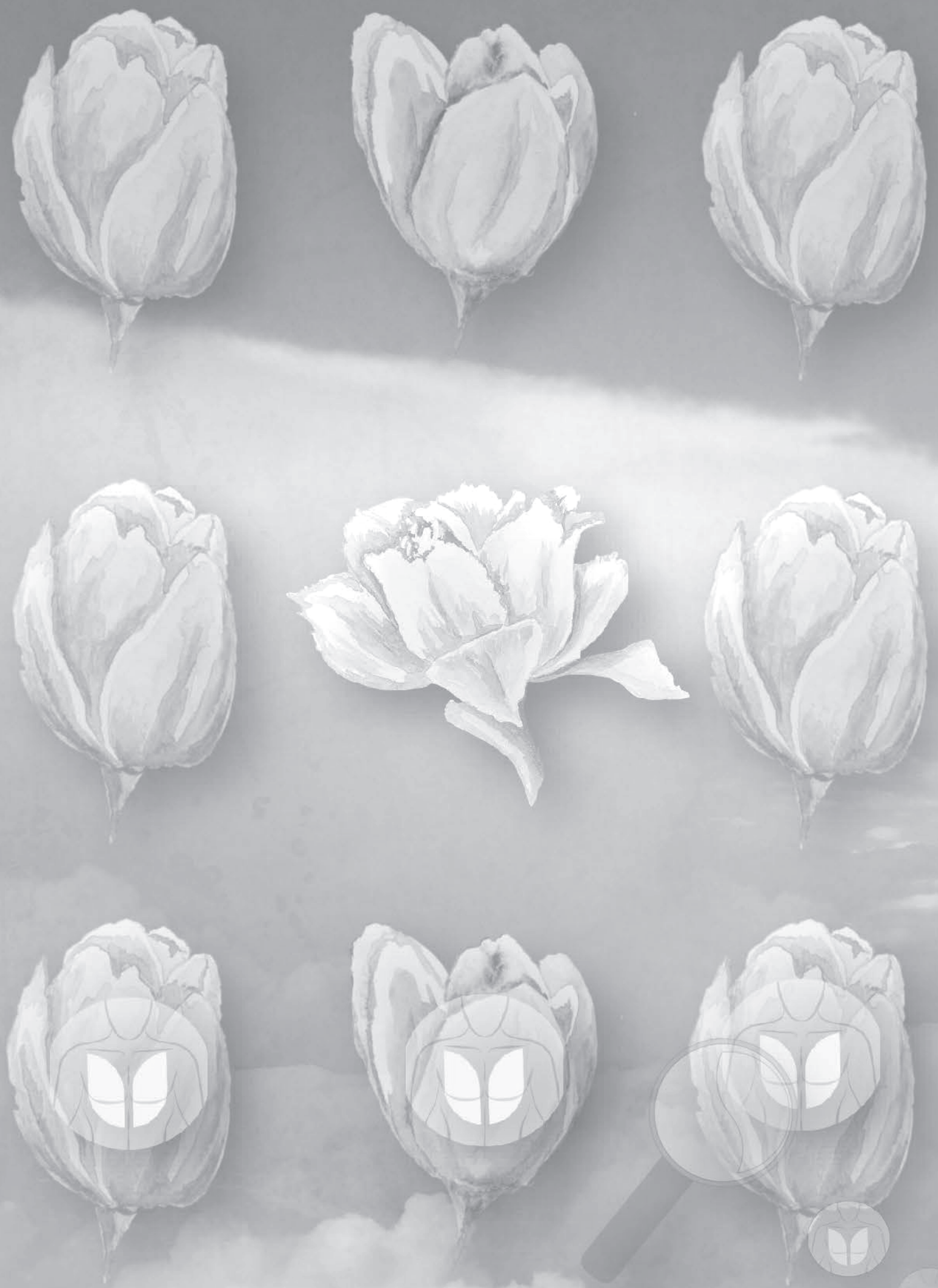


\section{Chapter 4}

Early detection of COPD in general practice: implementation, workload and socioeconomic status. A mixed methods observational study

J.A.M. Dirven, H.J. Tange, J.W.M. Muris, K.M.A. van Haaren, G. Vink, O.C.P. van Schayck

Primary Care Respiratory Journal 2013:22:338-343 


\section{Abstract}

\section{Background}

Chronic obstructive pulmonary disease (COPD) is underdiagnosed in general practice. Our aim was to implement a population-based approach for the early detection of COPD and to assess its impact on primary care workload and costs, and the influence of socioeconomic status (SES).

\section{Methods}

An observational study with mixed methods was performed in 10 Dutch general practices of either low or moderate to high SES. The Respiratory Health Screening Questionnaire was posted during a three-month period to all persons aged 45,55 , and 65 years (one age group per month). The practices calculated the risk, and patients at high risk of COPD were invited for spirometry at the practice. The general practitioner used the spirometric results and a consultation to establish a clinical diagnosis. Qualitative and quantitative data on workload, cost, and barriers were evaluated.

\section{Results}

Ten practices returned 293 (35.3\%) COPD risk tests for the three age groups. Participants from low SES practices responded better than those from moderate to high SES practices ( $40.8 \%$ vs. $30.5 \%)$. In practices with low SES $17.9 \%$ of the tests indicated high risk compared with $16.1 \%$ in practices with moderate to high SES. Nine patients $(23 \%)$ were newly diagnosed with COPD. The healthcare providers' extra workload averaged 18.5 hours during the three months for one standard practice. The average cost of this survey programme (three age groups in three months) was $€ 520$ for low SES practices and $€ 398$ for moderate to high SES practices. All healthcare providers affirmed that the extra workload in this survey model is acceptable and feasible when finances are compensated.

\section{Conclusions}

Early detection of COPD is feasible in daily life primary care. In moderate to high SES practices the costs of detecting COPD were less than in low SES practices. 


\section{Introduction}

Chronic obstructive pulmonary disease (COPD) is a progressive disease which usually begins many years before it is diagnosed. Many patients with COPD remain undiagnosed and are potentially unknown to healthcare providers. (1) Previous epidemiological studies in Europe have shown that COPD affects $9 \%$ of the adult population, of whom most are smokers. $(2,3)$ The prevalence of COPD in Dutch general practices is $2 \%$. In many western countries a further $2 \%$ of COPD cases remain undiagnosed. (4)

The reasons for underdiagnosis of COPD have mainly been reported as underuse of spirometry by doctors and the lack of awareness by patients of signs, symptoms, and risk factors. This is especially important in the early stages of the disease as early COPD may already impair daily activities and reduce the quality of life. (5)

Early detection is relevant and may lead to people being able to perceive their symptoms. Besides symptoms, people with undetected COPD have many lifestyle problems including smoking and lack of daily physical activity. Smoking is the most preventable cause of premature death, 6 and smoking cessation is a very costeffective measure. 7 In COPD it can have a positive effect on the impact and progression of the disease. (8) The health benefits and long-term effects of reduced tobacco consumption are well documented. $(9,10)$

Many people with smoking-related illnesses visit general practices every year.11 As many as $80 \%$ of smokers visit their general practitioner (GP) once or more annually. (12) Thus, general practices offer a good opportunity for smoking cessation interventions. (13)

Low socioeconomic status (SES) is an important risk factor for COPD, and it is not well known how low SES groups cope with their lifestyle. In people with low SES there is a higher prevalence of COPD, (14) whether or not they smoke. (15) Low SES correlates significantly with lower lung function, even after adjustment for smoking status, occupational exposures, and race or ethnic origin. (16)

People with low SES participate less in online mass interventions, and those with a low educational level use the internet less frequently, as do addicted young smokers. (17) If low SES groups are recruited, they refrain from follow-up actions more often than moderate to high SES groups. (18) We know that there are many smokers among undiagnosed COPD patients, especially in low SES groups. When the target group consists mainly of smokers with low SES, the most suitable and effective gateway for recruiting respondents is probably through general practice.(19)

The process of early detection of COPD in general practice is complex and requires a structured method of identifying patients with risk factors and symptoms of COPD in a stepwise manner. 
Mounting evidence suggests that early detection, adequate diagnosis, and maintenance treatment of COPD - along with smoking cessation and an increase in daily physical activity - may help to provide symptom control, lessen disease progression, and lead to better long-term outcomes for COPD. (20) There have been several initiatives to develop COPD case-finding programmes in specific risk groups and in different clinical settings. (21-25) Stepwise early detection programmes with a population-based approach seem to be feasible in an experimental research setting. (26-28)

An evidence base for an early detection programme of COPD as such is not enough to introduce this programme successfully into clinical practice. In general, there is a gap between the introduction of a guideline and its effective use. Lugtenberg et al. found that, besides lack of evidence, organisational constraints, lack of knowledge by the user, and lack of clarity of the guideline itself are also important barriers for using the guideline. (29) It is therefore important to study and solve potential barriers for implementation before introducing a new nationwide guideline.

The aim of the present study was to evaluate the feasibility of implementing an early detection programme for COPD. Research questions were:

1. Are there barriers related to organisational factors such as workload and financial constraints?

2. Are there barriers related to user characteristics such as attitude or knowledge?

3. Are there barriers related to patient characteristics such as the dominant SES signature of the practice?

\section{Methods}

\section{Setting and design}

An early detection programme for COPD was implemented in 10 general practices in two cities in the south of the Netherlands in May, June and July 2012. The practices were stratified into two classes (Iow SES and moderate to high SES) based on postal codes according to the Dutch Health Authority public register. (30)

The implementation of the programme was studied in an observational study with a mixed methods design including both quantitative and qualitative methods. 


\section{Population}

Candidates for the early detection programme were all people aged $40-70$ years, excluding those already diagnosed with asthma or COPD or with other serious lung diseases such as lung cancer, pneumoconiosis, tuberculosis, bronchiectasis, and pneumonectomy. People using oxygen supplementation and those with impaired mobility were also excluded.

Five low SES practices and five moderate to high SES practices were randomly chosen from the public list of the Dutch Health Authority (30) and recruited. Prerequisites for participation were: (a) no involvement in another COPD early detection or case finding procedure in the last five years; (b) obligatory participation in the study of the GP, practice assistant (PA), and practice nurse (PN); and (c) available and recent electronic medical records (EMRs).

\section{Intervention}

The script of the early detection programme has been described in the COPD Prevention Consultation (CPC) model by the Dutch College of General Practitioners (31) and consists of four stages (Figure 4.1).

The first stage is to send out the Respiratory Health Screening Questionnaire (RHSQ), a validated questionnaire for screening patients at risk of COPD. $(32,33)$ It contains 10 simple questions about age, smoking history, body weight, height, and respiratory complaints (Table 4.1). The risk of COPD is determined by adding the points of individual items of the RHSQ score card: low risk ( $<16.5$ points), medium risk (16.5-19.5 points), or high risk ( $>19.5$ points).

There are two versions of the RHSQ. One version is meant for public use and includes the score card for self-calculation and was applied by the Dutch Lung Foundation in a mass media campaign (www.longfonds.nl/ontdek-copd-op-tijd). The other version is meant for use by family practices and does not include the score card. The PA sends the RHQS to eligible people and calculates the risk scores after return of the RHQS. The latter was used in this implementation study.

The second stage is capturing and analysing the RHSQ data in a Digital Risk Test (DRT) tool. People with a high-risk score are invited for spirometry. Other people only receive a letter with general lifestyle advice and a reference to the public website of the Dutch College of General Practitioners (www.thuisarts.nl).

The third stage is a consultation with the PN. During this consultation the Medical Research Council (MRC) dyspnoea scale and the Clinical COPD Questionnaire (CCQ) are filled out and postbronchodilator spirometry is performed. People with an abnormal spirometry test are then invited in for a doctor consultation.

The fourth stage is a consultation with the family practitioner. 
During this consultation the COPD diagnosis and GOLD stage is confirmed. A COPD diagnosis is based on the combination of a postbronchodilator $\mathrm{FEV}_{1} / \mathrm{FVC}$ ratio $<0.7$ and the physician's clinical evaluation (www.nhg.org). The follow-up procedure is explained and, when indicated, smoking cessation advice is given and/or medication is started. All data are recorded in the DRT tool.

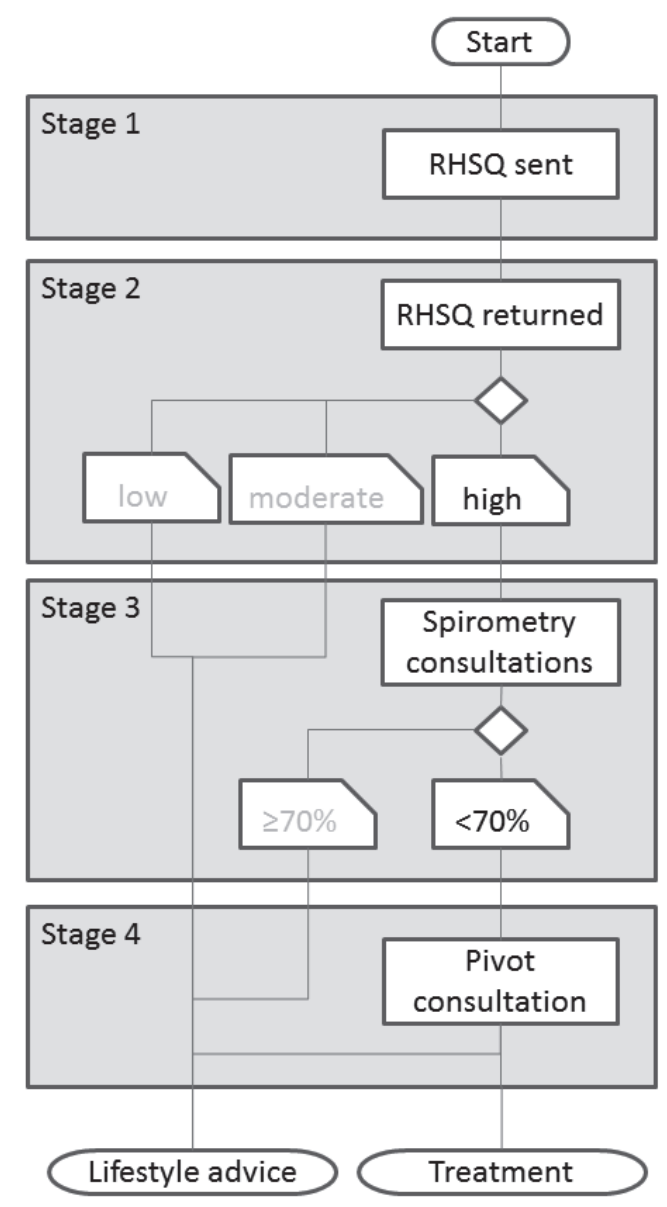

Figure 4.1 Script of the early detection programme.

RHSQ=Respiratory Health Screening Questionnaire 
Table 4.1 Respiratory Health Screening Questionnaire (RHSQ) score card.

\begin{tabular}{|c|c|c|c|}
\hline \multicolumn{2}{|c|}{ Question } & \multirow{2}{*}{$\begin{array}{l}\text { Answer } \\
40-49\end{array}$} & \multirow{2}{*}{$\frac{\text { Score }}{0}$} \\
\hline 1. & What is your age? & & \\
\hline & Age group, years & $50-59$ & 4 \\
\hline & & $60-69$ & 8 \\
\hline 2(a) & How many cigarettes have you smoked per day? & ....... cigarettes & \\
\hline \multirow[t]{2}{*}{ 2(b) } & Are you smoking now? & Yes 0 & \\
\hline & & No $\mathrm{O}$ & \\
\hline \multirow[t]{5}{*}{$3(\mathrm{a})$} & How many years have you smoked? & ....... years & \\
\hline & Pack years I have smoked & $0-14$ & 0 \\
\hline & & $15-24$ & 2 \\
\hline & & $25-49$ & 3 \\
\hline & & $50+$ & 7 \\
\hline 4. & What is your weight? & $\ldots \ldots \ldots \mathrm{kg}$ & \\
\hline \multirow[t]{4}{*}{5.} & What is your height? & ......... m & \\
\hline & Body mass index, $\mathrm{kg} / \mathrm{m}^{2}$ & $>29.7$ & 0 \\
\hline & & $25.4-29.7$ & 1 \\
\hline & & $<25.4$ & 5 \\
\hline \multirow[t]{3}{*}{6.} & Does the weather affect your cough? & Yes & 3 \\
\hline & & No & 0 \\
\hline & & Do not cough & 0 \\
\hline \multirow[t]{2}{*}{7.} & Do you have phlegm without a cold? & Yes & 3 \\
\hline & & No & 0 \\
\hline \multirow[t]{2}{*}{8.} & Do you have phlegm in the morning? & Yes & 0 \\
\hline & & No & 3 \\
\hline \multirow[t]{2}{*}{9.} & Do you wheeze (frequency)? & Never & 0 \\
\hline & & Sometimes or often & 4 \\
\hline \multirow[t]{2}{*}{10.} & Have or had any allergies? & Yes & 0 \\
\hline & & No & 3 \\
\hline
\end{tabular}

\section{Implementation strategy}

A short care providers' meeting was arranged in each practice to explain the aims and methods of the study and to confirm the prerequisites for participation. The indicated implementation strategy was to let practices include one age group each month, thus spreading the workload. For this three-month implementation study, all eligible people aged 45 were invited in the first month, those aged 55 in the second month, and those aged 65 in the third month. Respondents could complete the RHSQ on paper or electronically on a website. 


\section{Measurement instruments}

Patient data such as RHSQ results, spirometry results, GOLD stage and advice given were retrieved from the DRT tool.

The following practice/healthcare provider data were acquired:

- Workload was measured with a questionnaire (SCIT-z) administered to the GP, PN, and PA.

- Potential barriers for adoption and implementation of health innovations in primary care were inventoried by a validated questionnaire for healthcare providers. (34) This questionnaire includes a total of 27 questions about 24 aspects of the characteristics of the innovation, the healthcare provider, the patient, and contextual factors such as regulations and financial aspects (Table 4.2). All questions were scored on a 5-point Likert scale.

Table 4.2 Barriers and facilitators' assessment instrument.

\begin{tabular}{lll}
\hline & Domain & Aspect \\
\hline Innovation characteristics & 1 Innovation & Compatibility \\
& 2 Innovation & Time investment \\
3 Innovation & Specificity/sensitivity \\
4 Innovation & Didactic benefit \\
& 5 Innovation & Attractiveness \\
Care provider characteristics & 6 Care provider & Attitude/role perception \\
& 7 Care provider & Knowledge motivation \\
& 8 Care provider & Doubts innovation \\
& 9 Care provider & Life/working style \\
& 10 Care provider & Education \\
& 11 Care provider & Involvement \\
& 12 Patient & Age \\
& 13 Patient & Ethnicity \\
Patient characteristics & 14 Patient & Financial situation/SES \\
& 15 Patient & Number of patient contacts \\
& 16 Patient & Health status \\
& 17 Patient & Motivation to change \\
& 18 Context & Group norms/socialisation \\
& 19 Context & Reimbursement/insurance system \\
& 20 Context & Law/regulations \\
21 Context & Opening hours of practice \\
22 Context & Supporting staff \\
23 Context & Facilities \\
24 Context & Practice building \\
\hline
\end{tabular}

Grey boxes indicate significant barriers identified by the responding healthcare providers. SES=socioeconomic status. 


\section{Outcome measures}

1. Outcome measures for organisational feasibility were workload (in hours per staff member per practice) and cost per practice. Cost was calculated by the number of RHSQ tests and spirometry consultations needed to find one positive diagnosis, divided by their unit cost.

2. Outcome measures for user-bound feasibility were perceived barriers based on the scores of practice personnel on different dimensions of a validated questionnaire for assessing barriers and facilitators of health innovations.

3. Outcome measures for patient-bound feasibility were the differences in response to and the effectiveness of the early detection programme between low SES and moderate-to-high SES practices.

These quantitative outcome measures were extended with qualitative information from the semi-structured interviews of healthcare professionals.

\section{Analysis of data}

Most analyses were descriptive. Differences in participation rates were tested with $\chi^{2}$ or Fisher's exact tests.

\section{Results}

\section{Response, effectiveness, and SES}

A total of 831 RHSQ tests were distributed, of which 293 (35\%) were completed and returned (Table 4.3): $156(41 \%)$ from the 382 low SES practices and $137(31 \%)$ from the 449 moderate-to-high SES practices $(p<0.05)$. The website was used by 29 of the 156 respondents (19\%) in low SES practices and by 56 of the 137 respondents $(41 \%)$ in moderate-to-high SES practices $(p<0.01)$.

Overall, 50 respondents $(17 \%)$ had a high-risk score, $28(18 \%)$ in low SES practices and $22(16 \%)$ in moderate-to-high SES practices (NS). The response among high-risk respondents to an invitation for spirometry was $21(75 \%)$ in low SES practices and $18(82 \%)$ in moderate-to-high practices (NS). Nine $(23 \%)$ new COPD diagnoses were established, seven (33\%) in low SES practices and two $(11 \%)$ in moderate-to-high SES practices (NS).

\section{Workload}

The workload for the early detection programme was shared between the PA, PN, and GP. On average, a PA spent 9.5 hrs on the programme, a PN spent $6 \mathrm{hrs}$, and a GP spent $3 \mathrm{hrs}$ during the three months of the study (Table 4.4). Thus, in total, a standard practice team (1 GP + $1 \mathrm{PN}+1 \mathrm{PA})$ spent $18.5 \mathrm{hrs}$ in 
three months on the programme, varying from $14.5 \mathrm{hrs}$ for moderate-to-high SES practices to 26 hrs for low SES practices. As a result, the direct cost for practice personnel varied from $€ 398$ for moderate-to-high SES practices to $€ 520$ for low SES practices, with an average of $€ 460$ per practice.

Table 4.3 Response rates and yield of the early detection programme.

\begin{tabular}{lccc}
\hline Results & $\begin{array}{c}\text { All } \\
\text { practices }\end{array}$ & $\begin{array}{c}\text { Low SES } \\
\text { Moderate- } \\
\text { to-high SES }\end{array}$ \\
\hline Patients registered in practices & 23,100 & 11,000 & 12,100 \\
Patients aged 45, 55, 65 years & 956 & 425 & 513 \\
Patients with exclusion criteria & 107 & 43 & 64 \\
Number of RHSQs distributed & 831 & 382 & 449 \\
Responders on RHSQ* & $293(35 \%)$ & $156(41 \%)$ & $137(31 \%)$ \\
Responders on website* & 85 & 29 & 56 \\
High-risk score on RHSQ & $50(17 \%)$ & $28(18 \%)$ & $22(16 \%)$ \\
Underwent spirometry (high-risk) & $39(78 \%)$ & $21(75 \%)$ & $18(82 \%)$ \\
New COPD cases detected & $9(23 \%)$ & $7(33 \%)$ & $2(11 \%)$ \\
COPD cases detected per standard general practice (N=2,350) & 0.9 & 1.5 & 0.4 \\
\hline
\end{tabular}

* $\mathrm{p}<0.05,(\chi 2$ test). COPD=chronic obstructive pulmonary disease, RHSQ=Respiratory Health Screening Questionnaire, SES=socioeconomic status.

\section{Perceived barriers and facilitators and health provider satisfaction}

The barriers for successful implementation perceived by the majority of teams were the ethnicity and SES of patients and the absence of financial compensation and limited supporting staff of the practice. No barriers were perceived in the nature of the programme itself or in the qualifications of the care providers (Table 4.2).

The DRT tool was a welcome support for the early detection programme. The 45 mins reserved for spirometry consultation was considered short because of patient questions and administration. Healthcare providers would have preferred more time for spirometry consultation $(60$ mins). Healthcare providers considered that the extra workload spent on the programme was feasible for a short time but, in case the activities became structural, they felt they would need extra personnel together with financial compensation. 
Table 4.4 Workload per care provider during three months.

\begin{tabular}{|c|c|c|c|}
\hline Activity & $\begin{array}{c}\text { Care } \\
\text { provider }\end{array}$ & Hours & Total \\
\hline Practice Assistant (PA) & & & 9.5 \\
\hline \multicolumn{4}{|l|}{ Stage I: Questionnaire mailing } \\
\hline a. Performing computer extraction & PA & 1 & \\
\hline b. Compiling a mailing list using exclusion criteria & PA & 1 & \\
\hline c. Mailing procedure (addressing, folding, posting) & PA & 3.5 & \\
\hline \multicolumn{4}{|l|}{ Stage II: Assessing questionnaire respondents } \\
\hline \multicolumn{4}{|l|}{ using the Digital Risk Test (DRT) tool } \\
\hline a. Processing the scores into the DRT & PA & 2 & \\
\hline b. Processing website respondents scores & PA & 1 & \\
\hline c. Posting lifestyle letter to medium and low risk & PA & 1 & \\
\hline \multicolumn{4}{|l|}{ Posting invitation letter to high risk for spirometry } \\
\hline Practice Nurse (PN) & & & 6 \\
\hline \multicolumn{4}{|l|}{ Stage III: Performing spirometry } \\
\hline $\begin{array}{l}\text { a. One spirometry takes } 45 \text { mins (totally } 8 \text { spirometries performed) } \\
\text { b. Including processing MRC and CCQ score } \\
\text { c. Including making appointment with GP }\end{array}$ & PN & 6 & \\
\hline General Practitioner (GP) & & & 3 \\
\hline \multicolumn{4}{|l|}{ Stage IV: Physician consultation } \\
\hline a. Interpreting clinical finding including spirometry & GP & 1 & \\
\hline $\begin{array}{l}\text { b. Coaching patient and coordinating follow-up } \\
\text { (first month } 1 \mathrm{hr} \text {; second month } 0.5 \mathrm{hr} \text {; third month: } 0.5 \mathrm{hr} \text { ) }\end{array}$ & GP & 2 & \\
\hline Total PA and NP and GP hours & & & 18.5 \\
\hline
\end{tabular}

\section{Discussion}

\section{Main findings}

This study showed that early detection of COPD is feasible in daily general practice in terms of participation, workload, costs, and provider satisfaction. Practices found the workload to be feasible, but only had to invite one age group per month. The yield of new cases of COPD was worthwhile; in all practices the yield was $23 \%$ of highrisk spirometries and $33 \%$ in low SES groups, which is in line with the RCT published also in this issue of the PCRJ. (35)

The average response to the questionnaire mailing was $35 \%$. Other populationbased detection surveys 35 have achieved a similar rate of $35 \%$, and $33 \%$ in the Cardiovascular Prevention Consultation Survey in 2010. In the high-risk group, 
$78 \%$ were willing to undergo spirometry; this high percentage may be due to the direct invitation by the practice. Internet usage was 19\% in low SES groups and $41 \%$ in moderate to high SES groups. This trend is also found in studies using internet interventions for smoking cessation.

After evaluation the healthcare providers in the general practices assessed the script book for implementation as a comprehensive working tool (Table 4.2). They were motivated and had enough knowledge and education for participation. They recommended previous case finding of all respiratory diagnoses in the Eletronic Medical Dossier (EMD) before starting the early detection programme.

\section{Interpretation of findings in relation to previously published work}

To our knowledge there is no previously published implementation study measuring workload in a COPD screening programme.

\section{Strengths and limitations of this study}

The strength of this study is that it took place in a routine healthcare situation; all procedures took place in the daily practice setting where all medical activities continued as usual. The health workers were free to schedule the extra workload in their agenda. All PNs were qualified nurses and adequately trained spirometrists. Another strength of this study is the attention paid to the SES of the participants. A limitation is that we decided not to study the feasibility of early detection in the whole age cohort of $40-70$ years.

\section{Implications for future research, policy and practice}

Based on this study, we recommend early detection of COPD, especially in practices with a low SES signature. We advise spreading the extra workload over a longer period of two years and to invite only one age cohort per month. Diagnoses of COPD and asthma should be well documented in the Electronic Medical Record (EMR).

\section{Conclusions}

In this real-life COPD early detection programme the yield of new COPD diagnoses was substantial - considering the limited number of patients screened - and the associated workload seemed to be acceptable. Extra financial means are necessary to compensate for the extra hours of work. 


\section{References}

1. Global Initiative for Chronic Obstructive Lung Disease (GOLD). Global strategy for diagnosis, management, and prevention of COPD. Available from: www.goldcopd.com.

2. Lundback B, Nystrom L, Rosenhall L, Stjernberg N. Obstructive lung disease in northern Sweden: respiratory symptoms assessed in a postal survey. Eur Respir J 1991;4:257-66.

3. Sobradillo Pena V, Miravitlles M, Gabriel R, et al. Geographic variations in prevalence and underdiagnosis of COPD: results of the IBERPOC multicentre epidemiological study. Chest 2000;118:981-9. 4. Soriano JB, Zielinski J, Price D. Screening for and early detection of chronic obstructive pulmonary disease. Lancet 2009;374:721-32.

5. Miravitlles M, Soriano JB, Garcia-Rio F, et al. Prevalence of COPD in Spain: impact of undiagnosed COPD on quality of life and daily life activities. Thorax 2009;64:863-8.

6. World Health Organization. WHO Report on the Global Tobacco Epidemic: the MPOWER package. Geneva: World Health Organization, 2008.

7. Anthonisen NR, Connett JE, Kiley JP, et al. Effects of smoking intervention and the use of an inhaled anticholinergic bronchodilator on the rate of decline of FEV ${ }_{1}$. The Lung Health Study. JAMA 1994;272:1497-505.

8. Pisinger C, Godtfredsen NS. Is there a health benefit of reduced tobacco consumption? A systematic review. Nicotine Tob Res 2007;9:631-46.

9. Godtfredsen NS, Lam TH, Hansel TT, et al. COPD-related morbidity and mortality after smoking cessation: status of the evidence. Eur Respir J 2008;32:844-53.

10. Bize R, Burnand B, Mueller Y, Rege WM, Cornuz J. Biomedical risk assessment as an aid for smoking cessation. Cochrane Database Syst Rev 2009;2.

11. van den Berg $M$, de Bakker D, Kolthof $E$, Cardol M, van den Brink-Muinen A. De werkdruk van de huisarts: zorgvraag en arbeidsduur in 1987 en in 2001. [The general practitioner's workload: demand for care and working hours in 1987 and 2001.] Medisch Contact 2003;58:1054-6.

12. Richmond R, Kehoe L, Webster I, Wodak A, Heather N. General practitioners' promotion of healthy lifestyles: what patients think. Aust NZ J Public Health 1996;20:195-200.

13. Stead LF, Bergson G, Lancaster T. Physician advice for smoking cessation. Cochrane Database Syst Rev 2008.

14. Kanervisto M, Vasankari $T$, Laitinen $T$, Heliovaara M, Jousilahti $P$, Saarelainen S. Low socioeconomic status is associated with chronic obstructive airway diseases. Respir Med 2011;105:1140-6.

15. Yin $\mathrm{P}$, Zhang M, Li $\mathrm{Y}$, Jiang $\mathrm{Y}$, Zhao $\mathrm{W}$. Prevalence of COPD and its association with socioeconomic status in China: findings from China Chronic Disease Risk Factor Surveillance 2007. BMC Public Health 2011;11:586.

16. Hegewald MJ, Crapo RO. Socioeconomic status and lung function. Chest 2007;132:1608-14.

17. Etter JF, Perneger TV. A comparison of cigarette smokers recruited through the Internet or by mail. Int J Epidemiol 2001;30:521-5.

18. Dalstra JA, Kunst AE, Geurts JJ, Frenken FJ, Mackenbach JP. Trends in socioeconomic health inequalities in the Netherlands, 1981-1999. J Epidemiol Community Health 2002;56:927-34.

19. Marmot M. Social determinants of health inequalities. Lancet 2005;365:1099-104.

20. Price D, Freeman D, Cleland J, Kaplan A, Cerasoli F. Earlier diagnosis and earlier treatment of COPD in primary care. Prim Care Respir J 2011;20:15-22.

21. Buffels J, Degryse J, Liistro G. Diagnostic certainly, co-morbidity and medication in a primary care population with presumed airway obstruction: the DIDASCO2 study. Prim Care Respir $J$ 2009;18:34-40.

22. Vandevoorde J, Verbanck S, Gijssels L, et al. Early detection of COPD: a case finding study in general practice. Respir Med 2007;101:525-30.

23. Geijer RMM. Detection of COPD in smokers. Thesis. Julius Center for Health Sciences and Primary Care, University Medical Center, Utrecht, The Netherlands, 2006.

24. Stratelis G, Jacobsson P, Molstad S, Zetterstrom O. Early detection of COPD in primary care: screening by invitation of smokers aged 40 to 55 years. Br J Gen Pract 2004;54:201-06. 
25. Piperno D, Bart F, Serrier P, Zureik M, Finkielsztejn L. [General practice patients at risk of chronic obstructive pulmonary disease.] Presse Med 2005;34:1617-22.

26. van Schayck CP, Halbert RJ, Nordyke RJ, Isonaka S, Maroni J, Nonikov D. Comparison of existing symptom-based questionnaires for identifying COPD in the general practice setting. Respirology 2005;10:323-33.

27. Calverley PM, Nordyke RJ, Halbert RJ, Isonaka S, Nonikov D. Development of a populationbased screening questionnaire for COPD. COPD 2005;2:225-32.

28. Dirven JAM, Muris JWM, van Schayck CP. COPD screening in general practice using a telephone questionnaire. J COPD 2010;5:352-9.

29. Lugtenberg M, Zegers-van Schaick JM, Westert GP, Burgers JS. Why don't physicians adhere to guideline recommendations in practice? An analysis of barriers among Dutch general practitioners. Implement Sci 2009;4:54.

30. Nederlandse Zorgautoriteit. Available from: www.nza.nl.

31. Pilot COPD Prevention Consultation. Dutch College of General Practitioners, Utrecht, 2012.

32. Price DB, Tinkelman DG, Halbert RJ, et al. Symptom-based questionnaire for identifying COPD in smokers. Respiration 2006;73:285-95.

33. van Schayck CP, Loozen JM, Wagena E, et al. Detecting patients at a high risk of developing chronic obstructive pulmonary disease in general practice: cross sectional case finding study. BMJ 2002;324:1370.

34. Peters MAJ, Harmsen M, Laurant MGH, Wensing M. Room for improvement? Barriers to and facilitators for improvement of patient care. Nijmegen: Centre for Quality of Care Research (WOK), Radboud University Nijmegen Medical Centre, 2002.

35. Dirven JAM, Tange HJ, Muris JWM, van Haaren KMA, Vink G, van Schayck CP. Early detection of COPD in general practice: patient or practice managed? A randomised controlled trial of two strategies in different socioeconomic environments. Prim Care Respir $J$ 2013;22(3):331-7. 

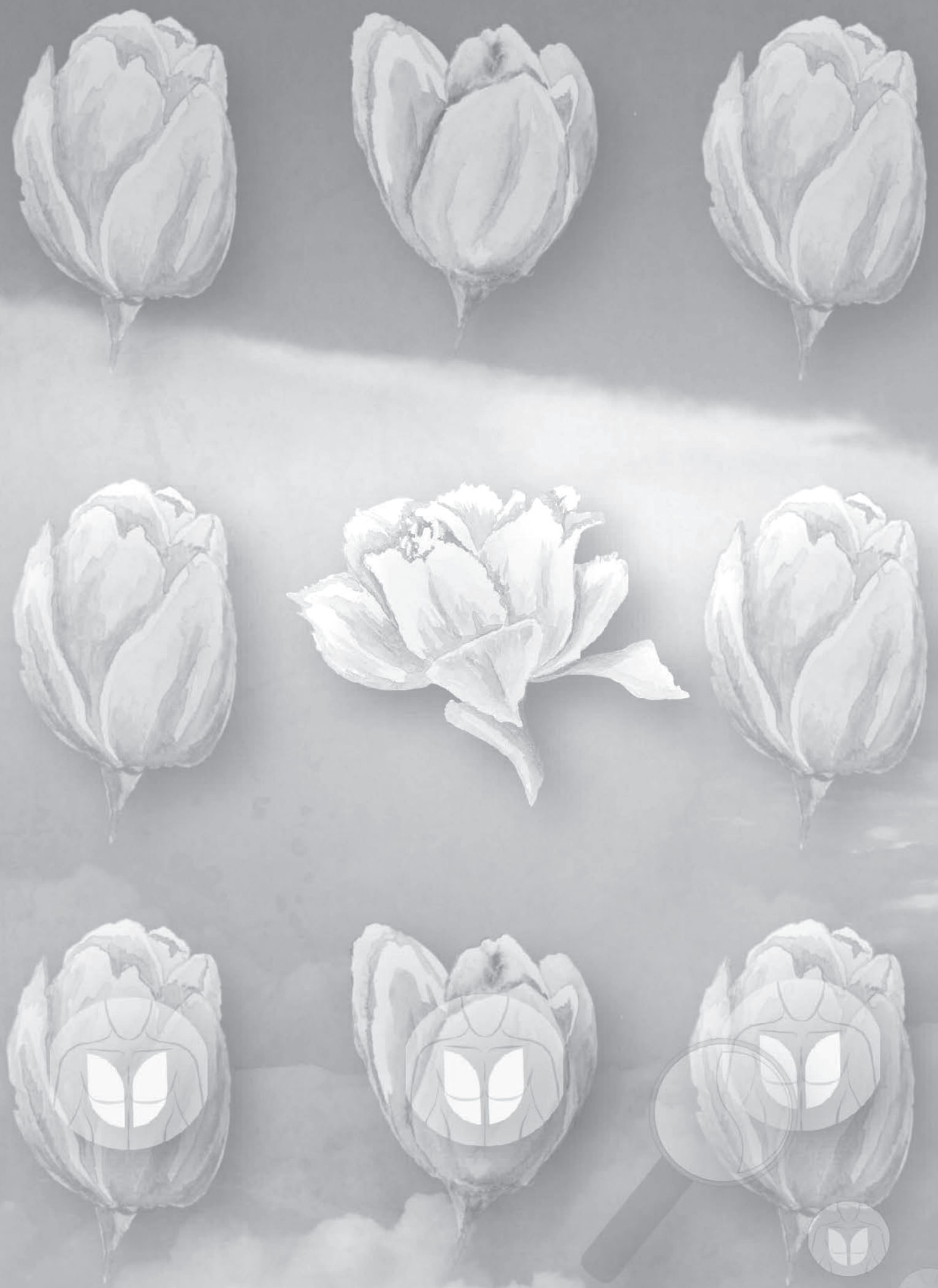


\section{Chapter 5}

An innovative COPD early detection programme in general practice: evaluating barriers to implementation

J.A.M. Dirven, A. Moser, H.J. Tange, J.W.M. Muris, O.C.P. van Schayck.

NPJ Primary Care Respiratory Medicine 2014;24:14055. 
In the Netherlands an innovative programme for early detection of COPD in primary care among patients aged 40-70 years has been evaluated in both an effect study and a pilot implementation study. Healthcare providers identified four obstacles for successful implementation of a COPD early detection programme. This communication letter will describe in brief the most important results of a qualitative study using in-depth interviews.

The Dutch programme for early detection of chronic obstructive pulmonary disease (COPD) in primary care among patients aged $40-70$ years consists of the Respiratory Health Screening Questionnaire (1) followed by spirometry. The effect study (2) showed that this approach would lead to $20 \%$ more known COPD cases in Dutch general practices, and the implementation study (3) showed that it was feasible for general practices to adopt this programme.

However, a validated written questionnaire among five clusters of 39 health-care professionals (4) also identified four potential obstacles for success: two perceived barriers were related to the provider (need for assistance and financial compensation). The two others were related to the patient (socio-economic status (SES) and ethnicity) (Table 5.1). The format of Table 5.1 is based on Peters et al (4), the contents of Table 5.1 is based on Dirven et al (3). As the Dutch College of General Practitioners intends to implement this programme nation-wide, it is important to have more insight into these barriers, so we explored them in depth in a qualitative study. We conducted semistructured face-to-face interviews (5) with five doctors and four practice nurses who were involved in the already-mentioned implementation study. (3) The interviews were audiotaped and parsed through directed content analysis. (6) In this Brief Communication we share the results of this unpublished study.

\section{Provider-bound barriers: Workload and financial compensation}

Health-care providers were confident of having enough knowledge to work out preventive activities, but expressed their need for a work-up protocol to follow the consecutive steps of the programme and for helpdesk support. Most of them perceived preventive activities as a challenging task and as an intrinsic part of their responsibility. Contracting out COPD prevention was no option. They considered COPD early detection as part of a stepwise integrated care approach next to other activities such as case finding. If revenues would remain low, however, they feared that the burden of extra effort and stress to reach programme deadlines over a longer period might cause feelings of frustration among health-care providers. They preferred a 5-yearly early detection 
programme, in which activities are concentrated in 3-6 months. They wished to be facilitated by receiving information in advance about current and expected new COPD cases, expected patient response, revenue, workload, cost and financial compensation. Extra workload should be accompanied by an increase in supportive staff and should be financially compensated. Some respondents expected that such measures would work as a stimulus for adopting the programme. Others were not certain if the programme would be reimbursed, since health-care insurance companies take the position that preventive activities in primary care should not be compensated. Yet, most interviewed doctors prompted that general practices are the most appropriate place for implementation of the early-detection programme, because all required facilities are available (such as rooms, tools and instruments).

Table 5.1 Barriers and Facilitators Assessment Instrument.

\begin{tabular}{|c|c|c|}
\hline Domain & & Aspect \\
\hline \multicolumn{3}{|c|}{ Innovation characteristics } \\
\hline 1 & Innovation & Compatibility \\
\hline 2 & Innovation & Time investment \\
\hline 3 & Innovation & Specificity/sensitivity \\
\hline 4 & Innovation & Didactic benefit \\
\hline 5 & Innovation & Attractiveness \\
\hline \multicolumn{3}{|c|}{ Care provider characteristics } \\
\hline 6 & Care provider & Attitude/roll perception \\
\hline 7 & Care provider & Knowledge motivation \\
\hline 8 & Care provider & Doubts innovation \\
\hline 9 & Care provider & Life/working style \\
\hline 10 & Care provider & Education \\
\hline 11 & Care provider & Involvement \\
\hline \multicolumn{3}{|c|}{ Patient characteristics } \\
\hline 12 & Patient & Age \\
\hline 13 & Patient & Ethnicity \\
\hline 14 & Patient & Financial situation/SES \\
\hline 15 & Patient & Number patient contacts \\
\hline 16 & Patient & Health status \\
\hline 17 & Patient & Motivation to change \\
\hline \multicolumn{3}{|c|}{ Context characteristics } \\
\hline 18 & Context & Group norms/socialisation \\
\hline 19 & Context & Reimbursement/ insurance system \\
\hline 20 & Context & Law/regulations \\
\hline 21 & Context & Opening hours of practice \\
\hline 22 & Context & Supporting staff \\
\hline 23 & Context & Facilities \\
\hline 24 & Context & Practice building \\
\hline
\end{tabular}


Practice nurses perceived potential barriers among the administrative procedures, such as customising invitational letters and administering questionnaires with login codes and registration numbers. Other inconvenient experiences were ill-timed over-the-desk question handling and unplanned efforts to persuade patients to have spirometry.

\section{Patient-bound barriers: Socioeconomic status (SES) and ethnicity}

Health-care providers felt that patients basically appreciated earlydetection activities. Their perceptions of non-compliant behaviour among low-SES patients, however, varied. Providers from practices with predominantly moderate and high-SES patients showed more scepticism and doubt about the return on investment of the programme for low-SES patients. They noticed less compliance from this group, while investing more time with them for explanation and counselling. Providers from practices with predominantly low-SES patients, on the other hand, were less pessimistic and showed more compassion regarding this low compliance. They were more motivated and creative in finding alternative ways to keep these patients aboard. Providers of moderate-high SES practices other than these of low-SES practices stated that their low-SES patients 'don't show up'; 'are often very difficult to deal with'; 'say yes and do no'; and 'are difficult to treat because they refer to their unhealthy peer group'. Such statements suggest that doctors in moderate-high-SES practices have lower outcome expectancy and lower self-efficacy towards low-SES patients than doctors in low-SES practices. This is a reason for concern, as when a physician does not believe that a recommendation will lead to an improved outcome (s)he will be less likely to adhere to the guideline. (7) Within the group of low-SES patients, heavy smokers were considered the most reluctant to respond to the programme, although these patients appeared to be aware of the bad consequences of smoking. Some health-care providers explained this reluctance by the suggestion that heavy smokers were inclined to lose self-confidence and assume a victim role. Care providers commented on low-SES smokers as a separate risk group because 'they have been more reluctant to show up', while contrastingly 'they like to learn about their health status'. Low-SES doctors, other than moderate-high-SES doctors, mentioned they felt commitment to deal with this specific group. All care providers were proposing that low-SES smokers show 'a frail motivation to quit smoking' and also that 'their motivation decreases in case of lesser complaints or symptoms'. Care providers think that low-SES smokers seem to be well aware of the bad consequences of smoking because 'they think they even will die because of this'. Most of them are also aware of 'not being able to quit and think they fail when they are not successful in quitting 
smoking'. Providers proposed 'they rather choose the victim role than quit smoking and subsequently refrain from practice visits because of feeling guilty'. In literature we can find similar statements: 'Current smokers feel ashamed and guilty about their disapproved lifestyle where social exclusion increases defensive actions and no show'. (8) Subsequently, doctors proposed to refrain from short separate quit smoking warnings during consultations. It was observed that compliance problems accumulated among ethnic patients, due to the frequent combination of low SES, heavy smoking and low literacy. There were doctors who suggested treating this whole group as high risk for COPD, recommending direct spirometry testing without the preceding questionnaire.

To the best of our knowledge no such studies as the one presented here and the ones published earlier in this Journal $(2,3)$ have been published before. Therefore it is difficult to compare different implementation strategies of early detection of COPD in the Netherlands with other countries. However, we believe that this subject is highly relevant, also in countries with developing economies. Especially in the latter countries we know that the exposure to indoor pollution due to the use of biomass fuel is leading to high incidences of COPD in women. $(9-11)$

\section{Conclusions}

Although it has been demonstrated that an early detection programme for COPD in primary care is feasible and effective, it is not a guarantee for successful implementation. Our study shows that qualitative exploration of experiences from a pilot implementation yields valuable information about barriers that may hamper its introduction or flaw its effect. We suggest that policymakers take into consideration the solutions brought forward by the interviewees in our study. 


\section{References}

1. Schayck CP, van Halbert RJ, Nordyke RJ, Isonaka S, Maroni J, Nonikov D. Comparison of existing symptom-based questionnaires for identifying COPD in the general practice setting. Respirology 2005;10:323-333.

2. Dirven JA, Tange HJ, Muris JW, van Haaren KM, Vink G, van Schayck OC. Early detection of COPD in general practice: patient or practice managed? A randomised controlled trial of two strategies in different socioeconomic environments. Prim Care Respir J 2013;22:331-337.

3. Dirven Joseph AM, Tange Huibert J, Muris Jean WM, van Haaren Karin MA, Vink Gerrit, Onno $\mathrm{CP}$ et al. Early detection of COPD in general practice: implementation, workload and socioeconomic status. A mixed methods observational study. Prim Care Respir J 2013;22: 338-343.

4. Peters MAJ, Harmsen M, Laurant MGH, Wensing M. Room for Improvement? Barriers to and Facilitators for Improvement of Patient Care. Centre for Quality of Care Research (WOK), Radboud University Nijmegen Medical Centre: Nijmegen, 2002.

5. Rabionet SE. How I learned to design and conduct semi-structured interviews: an ongoing and continuous journey. Qual Rep 2011;16:563-566.

6. Hsieh HF, Shannon SE. Three approaches to qualitative content analysis. Qual Health Res 2005;15:1277-1288.

7. Bandura A. Social Foundations of Thought and Action: A Social Cognitive Theory. PrenticeHall: Englewood Cliffs, NJ, USA, 1986.

8. Lindqvist G, Hallberg LRM. Feelings of guilt due to self-inflicted disease: a grounded theory of suffering from chronic obstructive pulmonary disease (COPD). J Health Psychol 2010;15: 456-466.

9. Salvi S, Barnes PJ. Is exposure to biomass smoke the biggest risk factor for COPD globally? Chest 2010;138:3-6.

10. Kurmi OP, Lam KB, Ayres JG. Indoor air pollution and the lung in low- and medium-income countries. Eur Respir J 2012;40:239-254.

11. World Health Organization. Fuel for life-household energy and health. World Health Organization, 2006. http://www.who.in1/indoorair/publications/fuelforlife.pdf. 

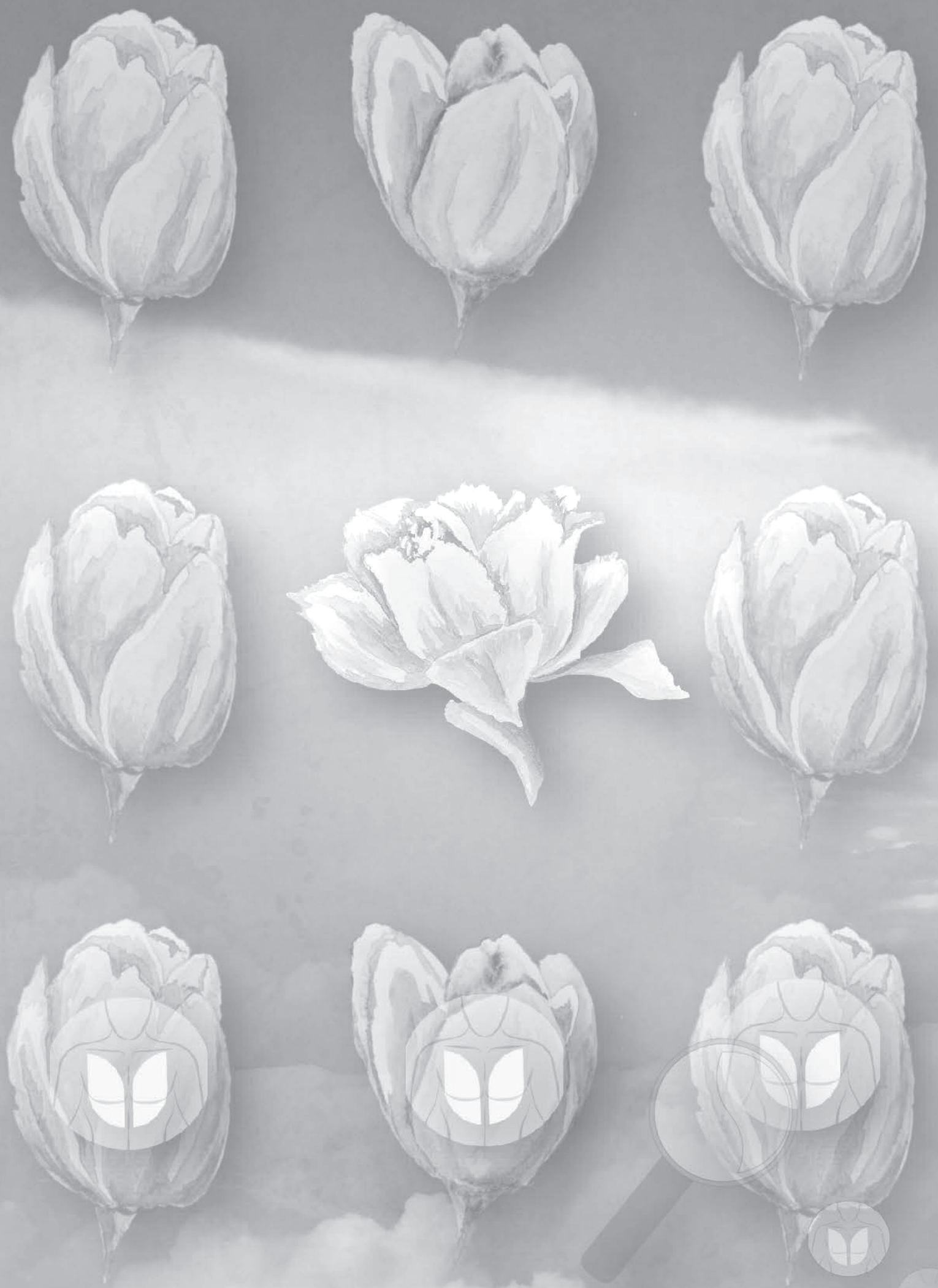


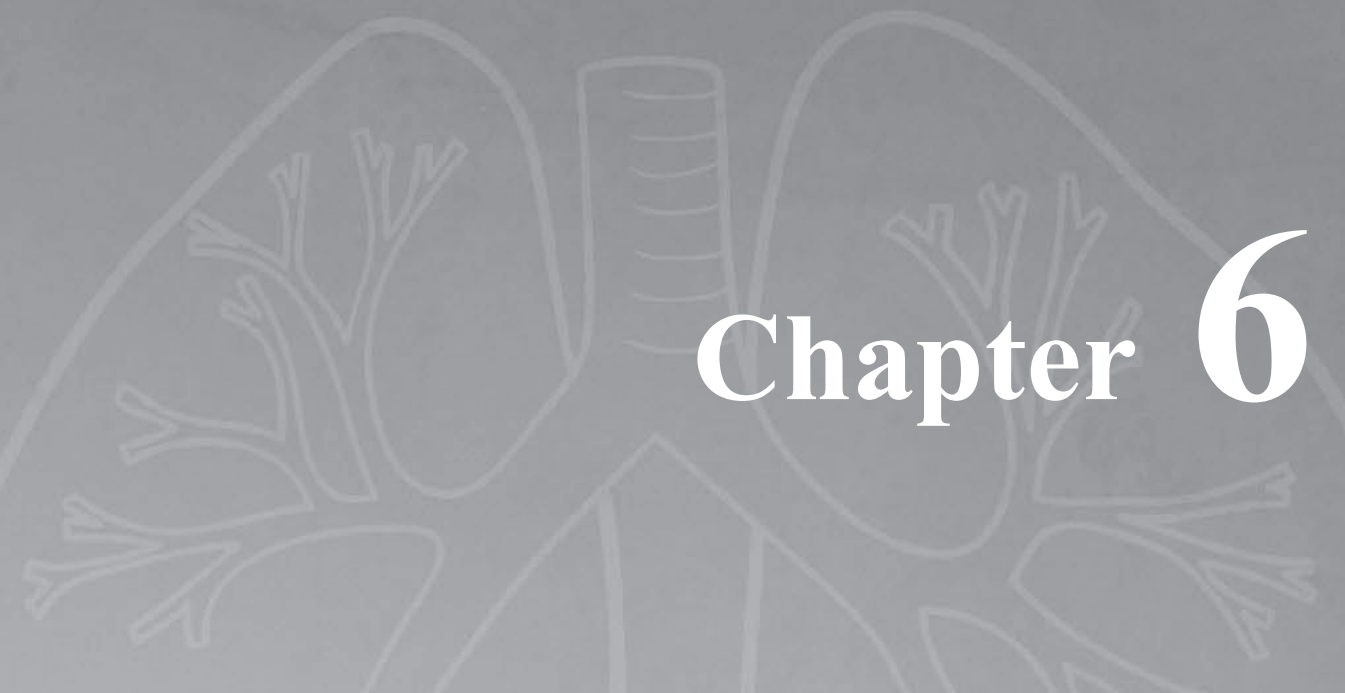

\section{General discussion}




\section{General discussion}

Chronic Obstructive Pulmonary Disease (COPD) is underdiagnosed in general practice especially in the early stages of the disease. Presentation to the General Practitioner (GP) is poor when respiratory symptoms are not perceived by the patient. The main aim of the research project reported in this thesis was to compare different strategies of early detection of COPD. This thesis reports on effectiveness, workload and barriers to implementation of two different strategies. In this chapter the main findings are summarized and discussed in the light of recent scientific literature. The barriers to and facilitators of implementation are discussed, as are the strengths and limitations of the studies conducted in this thesis. Finally, general conclusions and recommendations are presented.

\section{Main findings from this thesis}

COPD is a common but underdiagnosed disease. $(1,2)$ In the Netherlands there is a marked difference between the number of COPD patients registered in general practice and the prevalence of COPD established in population-based studies. $(3,4)$ A reason for this discrepancy could be that undetected COPD patients do not perceive and therefore not present their symptoms in the early stages of the disease and avoid seeking medical attention. $(5,6,7)$

Case-finding or targeted screening strategies could offer the opportunity to detect patients with COPD that are unknown to the general practitioner. In this thesis we have studied two different strategies.

Chapter 1 describes COPD as an underdiagnosed disease with smoking and low socioeconomic status as most important interfering risk factors. Reasons for early detection and differences between screening and case-finding have been highlighted and results of previous initiatives have been compared. The two main aims of targeted screening have been applied in the next chapters.

Chapter 2 describes the first strategy, namely the deployment of a call-centre that used a telephone questionnaire for targeted population-based screening. This active and personal approach was evaluated in a cross-sectional observational study (8) and yielded a high response and a high number of newly diagnosed COPD patients but at high cost. We concluded that this strategy is effective but would result in substantially more workload. This made us presume that a cheaper approach involving written questionnaires instead of telephone questionnaires would even be more effective.

Chapter 3 reports on the second strategy of targeted population-based screening, on a larger scale, and using a posted written questionnaire with a 
variation in the involvement of the GP-staff. (9) We conducted a randomized controlled trial (RCT) comparing a patient-managed and a practice-managed approach. The response and the number of newly detected COPD cases in the practice-managed approach was higher than in the patient-managed approach. Notably, the yield in practices with predominantly low-SES patients was higher than in moderate- to high-SES practices. We concluded that the second strategy was preferable and best effectiveness was achieved in the practice-managed approach.

Chapter 4 presents the results of an implementation study in a restricted number of participants based on age, of the practice-managed COPD early detection programme described in the previous chapter. (10) This real-life implementation study generated a substantial yield of new COPD diagnoses, especially considering the limited number of patients that were screened. Moreover, the associated extra workload appeared to be acceptable, although the GPs indicated that extra financial means would be necessary to compensate for extra hours of work. The workload for detecting COPD was less in moderateto high-SES practices than in low-SES practices.

Chapter 5 reports a qualitative analysis of barriers that were encountered during the implementation study described in chapter 4. These barriers (regarding workload, costs, low socioeconomic status (SES) patients and ethnicity ) have been evaluated in depth by conducting face-to-face semi-structured interviews with healthcare providers from the GP practice. The interviews were transcribed verbatim and analysed by direct content analysis. The conclusions from these data are published in chapter 5. (11)

\section{Comparison with the literature}

We found only two other comparative studies: one on case finding by Bunker et al. (12) and one pilot randomized controlled trial on screening by Haroon et al. (13) Response and yield of new COPD in these studies were lower than in our programme. They used different inclusion criteria by targeting only ever-smokers from 35 until 80 years. They did not use a strategy of targeting at high risk by using a (COPD detecting) questionnaire. A reason of a lower yield of new COPD as in our studies could be low response of only ever-smokers without targeting at symptoms. Another reason could have been higher participant support in our practice-managed strategy by explanatory letters and posted (or telephone) invitational letters to join for spirometry in case of high risk score.

In literature we found two non-comparative screening studies by Lings $\varnothing$ et al. (14) and by Ulrik et al. (15) showing a high yield of new COPD diagnoses. In the study by Lings $\varnothing$ this can be explained by inclusion of only subjects aged 65 
years and over, and in the study by Ulrik the inclusion of only ever-smokers who had at least one respiratory symptom. This study used one symptom as an inclusion criteria and did not perform post-bronchodilation spirometry which both could explain a higher yield of COPD, since this may lead to false positive diagnoses.

The earlier studies using targeted population-based screening had a yield of new COPD diagnoses which was about double that of opportunistic targeted screening studies (case-finding). $(16,17,18,19)$ The overall yield in case-finding studies depends mainly on the clinical alertness of doctors and nurses. A further advantage of targeted screening is that nearly all eligible participants are reached by a postal questionnaire, against only one third in case-finding. (13) In addition, it reaches relatively more current smokers especially in low-SES groups, so more smoking cessation interventions can be offered. (20)

The literature suggests that patients with undetected COPD generate higher costs than patients with known COPD, because their (unknown) exacerbations may not be adequately treated. (21) In a study by Maple et al. the extra direct healthcare costs of undetected COPD patients were calculated in an integrated managed care system. They found that patients with undetected COPD have substantially higher direct medical costs in the two years before their first COPD diagnosis than in the two years after the diagnosis as the greater part of the costs before a COPD diagnosis is attributable to hospitalization after an exacerbation.(22) This suggests that a COPD early detection programme might reduce not only the burden of exacerbations, but also the direct healthcare costs associated with exacerbations. But does this cost reduction outweigh the extra cost of a COPD early detection programme? Our results in (chapter 3 ) confirm this: that the direct cost of detecting one new COPD patient was only one sixth of the yearly additional direct cost for treating one undetected COPD patient reported in the Maple survey.

Both the response to questionnaires and the yield of new COPD diagnoses was higher in low-SES groups than in moderate-high-SES groups. We have two explanations for this unexpected phenomenon: the higher COPD prevalence in low-SES groups (23), and the fact that low-SES practice staff spends more time and effort in supporting low-SES patients. Yet, there is more room for improvement in low-SES groups as they are known for their poor compliance to follow-up activities. (24) Indeed, we found that the response of low-SES patients to spirometry and GP consultations was much lower, suggesting that low-SES patients need more encouragement than others to make them therapy compliant. $(20,25)$ 


\section{Implementation}

With our programme we successfully stimulated persons to recognize their hidden COPD symptoms by answering the specific screening questionnaire. In this section we will discuss the barriers and facilitators for a successful intervention.

\section{Barriers to implementation}

\section{Extra workload}

In the telephone study (chapter 2) the assumption is discussed that the response and recruitment to a screening programme might have been higher when the practice-assistant would have taken care of the invitation instead of a call centre. During the evaluation of the telephone-based programme doctors and nurses indicated that - in their experience - screenees showed higher adherence to screening programmes when invited by staff from their own practice than when first contacted by an external bureau. Furthermore they indicated that in case of a high risk score for COPD the practice assistant could immediately act and make an appointment for spirometry at the same moment of contact. The counterpart of such strategy is that phoning all eligible persons leads to a higher workload, both at daytime and in evening hours. Further study is necessary to find less demanding recruitment approaches to be performed by practice staff. Hence, in the following chapters we evaluated an approach using written questionnaires instead of using a call centre.

As mentioned before, the direct cost of early detection of COPD outweigh the direct cost of failing to detect COPD. But this fact is not enough to persuade GP practices to implement an early-detection programme. Practices are expected to implement several early detection programmes in the Netherlands, including those for cardiovascular disease (26) and diabetes mellitus (27). Implementing another programme aimed at COPD, concurrently and over a long period, is not a desirable prospect, because it could lead to extra workload for the GP. This may be an explanation for the fact that doctors in our study complained about time burden, although the extra time asked for the programme was very limited. Another barrier due to extra workload is the fact that many practices show a substantial number of prior COPD and asthma misdiagnoses in the Electronic Patient Records (EPR's). Doctors felt inclined to first re-assess existing respiratory diagnoses before they can start the early detection of other patients. 


\section{Confusing communication}

There have been questions from participants about the questionnaire, explanatory letter and practice attendance. Answers with advice, information and education have been provided immediately. For a good understanding, clear communication with patients is very important, but it is not always easy. In our practice-managed condition (chapter 3 ), the medium- and low-risk respondents were sent an explanatory letter in which was written that they had no risk of COPD at the moment. But in the same letter they were advised to adopt a healthy lifestyle with regard to smoking, weight control, daily activities or physical exercise or consult the professional self-management website of the Dutch College of General Practitioners (www.thuisarts.nl). This caused confusion.

Much time and effort had to be spent to persons who were confused about not receiving further follow-up from their doctor, as they thought that had been promised. Despite being informed in the explanatory letter that they were not at high risk, they were unhappy about having no spirometry. A few of them even persisted in having a spirometry because of their respiratory complaints. These examples illustrate the lessons we learned about the need of clear communication.

Another point of attention is that an early-detection programme only represents one momentum. People at high risk might interpret a normal spirometry result as indicating that they will not develop COPD. This false sense of reassurance is a psychological pitfall that should be recognized in any screening programme .(28) Such misunderstanding can even result in a real adverse effect of screening when people consider it an excuse to hold on an unhealthy lifestyle or even to start smoking again. Hence, appropriate expectations management should be an integral part of the communication about the COPD early detection programme. On the other hand, too comprehensive explanations hold the risk that people may feel patronized and get lost for the programme.

After participation in an early detection programme, people with normal spirometry findings who have questions should be counselled appropriately and given further information. These elements of advice and information imply that more time should be set aside for preparing a good communication programme about the effects and possible harm of screening activities. The positive effect of these activities will inevitably lead to more awareness of the disease.

\section{Specific barriers for low-SES smoking groups}

The opinions of the healthcare providers in our study are in line with evidence in the literature that low self-efficacy among low-SES smokers leads to defensive attitudes after getting stern warnings against their smoking behaviour. $(29,30,31,32)$ Straightforward admonitions by only emphasizing the adverse 
consequences, will frustrate relapsed quitters and might work counterproductively. This lack of result may lead to a disturbed patient-doctor relationship and smokers who turn away from their doctor. In this sense a person-centred and tailored advice would be more expedient.

A specific point of attention is our observation that healthcare providers from practices with predominantly moderate- and high-SES patients expressed more scepticism, pessimism and doubt about the return on investment of the early detection programme among their low-SES patients than providers from lowSES practices did. They noticed little compliance from this group, despite their time investment for explanation and counselling. Providers from practices with predominantly low-SES patients, on the other hand, were less pessimistic and showed more understanding regarding the lack of compliance of low-SES patients. They had higher outcome expectations from low-SES patients than their colleagues in moderate- to high-SES practices. They also showed more empathy and respect for these patients' behaviour. They spent more consultation time with their patients, while exploring alternative ways to keep these patients on board. An explanation for this patience and tailoredness might be abundancy of experience, skills, and knowledge concerning how to reach and treat low-SES patients. A possible way to spread this knowledge to doctors from moderate-high-practices is the establishment of intervision groups as part of the COPD early-detection programme.

\section{Lack of experience with spirometry}

Not addressed in this thesis, but yet an important barrier for COPD early detection is the underuse of spirometry tests in general practice, which reflects the lack of experience with spirometry. Only a properly trained staff and monitoring of spirometry quality will result in acceptable misclassification rates in primary care settings.(33) But remember that no single test is perfect: even experienced spirometry specialists differ in their interpretation of test results, and the reliability of their conclusions varies. (34) Another point of attention is that reversibility testing was not always an issue in the guidelines for COPD in general practice. This might be an explanation for the fact that former casefinding studies produced a higher yield of COPD diagnoses. $(35,36,18,19)$ Postbronchodilator spirometry instead of pre-BD spirometry prevents COPD overdiagnosis in about a quarter of all new diagnoses. (37) 


\section{Facilitators of implementation}

\section{High number of active smokers in a COPD screening programme}

The literature shows that early detection programmes in GP practice appear to persuade the highest percentage of lower educated smokers to participate and make a quit attempt. (38)

In our new programme, more than two third of newly diagnosed COPD patients were current smokers, and one third of them were motivated to start a smoking cessation intervention. The percentage of persons motivated for smoking cessation among the participants of our programme was uniquely high compared to reports in the literature on smoking cessation research. The reason for this might be the intensive three-step approach in our new programme, which involved posting a questionnaire with an explanatory letter, followed by spirometry and a consultation with the GP. These findings are encouraging for the implementation of future targeted screening programmes in general practice. The main aim of early diagnosis is to persuade patients to stop smoking, as cigarette smoking is the main causal factor of COPD in the Western world, and it is also the most important modifiable risk factor.(39,40) Since we know that the majority of COPD patients and patients 'at risk' of COPD are current smokers, and that their health perspective will improve after smoking cessation, the requirements of a screening programme would be met by administering recommended and recognized, evidence-based smoking cessation interventions. (41).

Such smoking cessation interventions could be undertaken by doctors and practice nurses, who are well able to administer them $(42,43)$. There is evidence that programmes involving the detection of new COPD cases could lead to higher smoking cessation rates. $(44,45,46)$ The use of supporting interventions by healthcare providers in GP practices to help patients quit smoking is well documented in international guidelines. (47) Management of smoking-related complaints of 'difficult patients' (i.e. those with comorbidities and those with multiple smoking cessation attempts) is most likely to be addressed in general practices. (48) And when the target group of smokers consists mainly of lowSES groups, the most suitable and effective gateway for recruiting respondents is probably also the general practice. (49)

\section{Questionnaires are able to detect delitescent symptoms}

Many people do have symptoms but do not report them. It is important to detect symptoms earlier and establish the COPD (or asthma) diagnosis $(50,51)$. If not, many COPD patients are diagnosed only after irreversible damage has already occurred to their lungs (52). Apart from their unreported symptoms, undiagnosed 
COPD patients among GOLD stage I may already show signs of impaired daily activities. (53) COPD exacerbations are well-known in patients with mild COPD even before diagnosis, but the symptoms are often not yet recognized by them as such. (54)

Our studies (chapter 3 ) provide evidence that, compared to being asked in a questionnaire, many people failed to report their respiratory symptoms during normal clinical consultation. Other studies confirmed this. $(55,56,35,36,5)$ One of the reasons for this behaviour might be that due to their adaptation to the severity of symptoms, COPD patients become poor perceivers of their symptoms of sputum or dyspnoea. $(57,58)$ We found a solution to this lack of awareness by using a questionnaire and an explanatory letter in screening programmes to enhance symptom awareness and reporting.

\section{Strengths}

The COPD early detection studies presented in this thesis have some strengths in common. An important strength was the recruitment method. The studies took place in a real-life setting. The extra workload was assessed under relatively well-controlled conditions. Recruitment took place in a well-defined general practice population, and participants received an invitation signed by their own doctor. These practice-related factors may have had a positive effect on patient compliance and response rate, compared to the only two existing comparative studies by Bunker et al. (12) and Haroon et al. (13).

After spirometry, participants were able to visit their own doctor within a few days. In contrast to the studies by Ulrik et al. (14) and by Lyngsø et al. (15), our procedure led to greater attendance, and has been especially beneficial in practices with a predominantly low-SES population. The recruitment strategy of our early detection programme made use of a validated questionnaire as a prescreening instrument. Pre-screening on persons at higher risk is likely to increase the yield. Lyngs $\varnothing$ and Ulrik did not use a validated questionnaire.

We cannot expect effects of spirometry screening in persons who have no respiratory symptoms. (59) Screening without pre-selection of at-risk patients would be a waste of healthcare resources. (60) In our programme the majority of respondents confirmed respiratory symptoms after having completed the questionnaire. They showed reluctance to visit the doctor earlier. They would not have presented their symptoms if we would not have asked. It is an advantage of the screening programme that persons with hidden respiratory symptoms can be detected. 


\section{limitations}

The COPD studies presented in this thesis had also some limitations.

In chapter 3 a cluster randomised controlled trial was conducted. The recruitment and allocation strategy could only be presented very briefly as it was published in a scientific journal with strict constraints to the size of the articles. In this General Discussion chapter we are in the position to explain more elaborately. Inclusion criteria for participation were: practice nurse and physician are five years or more working in the same practice; making use of electronic medical records (EMR) that utilizes the ICPC as a coding system; 25 or more known COPD diagnoses per practice; certified practice nurse available specialized in COPD and licensed to perform spirometry in the practice.

Totally 16 practices were recruited. The practices were stratified for socioeconomic status (SES) based on a postal code list of the Dutch Health Authority into low-SES practices and moderate to high-SES practices. Randomisation took place in both strata based on odd and even numbers in order of registration.

In fact we have conducted two methods: first a Generalized Estimating Equations (GEE) analysis which corrected for clusters and stratification. We found a very low Interclass Correlation Coefficients (ICC) (0.001 for the COPD risk-test and 0.005 for the spirometry test). Because of these low values and because GEE is a relatively unknown method which is difficult to interpret without explanation, we additionally performed a regular logistic regression analysis. As expected, this resulted in similar results as the GEE. In the publication only the results of the regression analysis were described, however it is erroneously written that these were corrected results. The following should have been stated instead: the results are not corrected for clusters. The editor of the journal has been notified about this error.

In the randomised controlled trial (chapter 3 ) we have given an indication of what the 'direct costs' for the practice organisation could be. It was a simple post hoc exercise to explore the possibilities for a further study to perform a real costbenefit analysis. It was certainly not our aim to perform a full-blown societal costbenefit analysis.

Initially we had the intention to describe the qualitative results of the implementation study in chapter 4. Eventually, these results have been presented in the next chapter (chapter 5) together with other qualitative work and published as a brief communication letter. In hindsight it would have been more consistent in chapter 4 to leave out all references to our qualitative work and describe it merely as a quantitative study.

In the script of the early-detection programme we have indicated four stages (chapter 4, Figure 4.1). Based on these stages we have developed a 
questionnaire for healthcare providers to report the duration of their activities in the screening programme. We have called this questionnaire the 'Screening COPD Implementation Tool' (SCIT-z). The mean results are presented in chapter 4, Table 4.4. It was striking that activities in the COPD early detection programme demanded less time from practices of moderate-high SES signature than from those with low SES signature.

In Table 4.2 of chapter 4 the results of the validated Barriers and Facilitators Assessment Instrument (BFAl) are presented. One questionnaire was distributed at all practice sites and returned from every location by the coordinating physician. The answers were based on the consultation of the staff at the practice site. The aim of the study was to detect characteristics which could be barriers to implementation. We performed an explorative analysis. The questionnaire is divided into four domains with 24 characteristics. A characteristic was labeled as a barrier when more than $50 \%$ of the participating practice sites had scored it as such. In this way, we found four barriers. Short thirty-minutes debriefings of each coordinating physician did not yield new perspectives on the outcome scores. This was the reason to initiate a separate in-depth interview study (chapter 5 ) to further elaborate on these barriers.

Chapter 5 was published as a 'brief communication letter', which format does not allow a full methodological description of the study. In this General Discussion chapter more details are presented. The study in chapter 5 had a qualitative design. From the GP surgeries as described in chapter 4, five doctors and four practice nurses were interviewed in depth using semi-structured interviews. Topics addressed were the four characteristics that were labeled as barriers in Chapter 4: need for assistance, need for financial compensation, socioeconomic status (SES) and ethnicity. The interviews were audiotaped, transcribed verbatim and parsed through direct content analysis.

Directed content analysis resulted in the following themes: conditions to work out preventive activities in the programme; dealing with extra workload; providers perceptions of non-compliant behaviour among low SES patients and low SES smokers as a separate group. These themes were presented and elaborated on in the text of chapter 5 .

In qualitative research desirability bias may occur when respondents give socially desirable responses to the questionnaires. For example, this may occur in normative questionnaires, with two possible answers (either/ or). In the BFAI questionnaires used in our study a five-point Likert scale was used. This will obtain a more realistic picture of the interests of the respondent than in the case of either/or answers. However, this does not exclude socially desirable answers. Next to questionnaires we have studied barriers to implementation by performing in-depth interviews. Interviews are also sensitive to socially desirable answers. The strong point of our research is the combination of questionnaires and in- 
depth interviews. The limitation is that we failed to verify what items might have given rise to socially desirable answers and that no social desirability scale was used.

In a little group of purposively sampled practice selection bias cannot be excluded. We tried to include practice with expertise in COPD. We did not succeed in including all types of practices and practices situated in villages or practices of the urbanized countryside were missing.

Epidemiologic screening studies, including our own study, are known to suffer from the phenomenon of recruitment bias. This means that persons having symptoms or a disease are more likely to participate than those without. (61) Half of the participants in our trial did not respond, and although we explored the reason for their non-response in a subsample of this group we did not collect enough information to study the distribution of risk factors and presence of respiratory symptoms in this group. However, our response rate is relatively high compared with the study by Haroon et al. (13)

In screening studies information and advice provided to participants should be clear and sufficient. In our studies we explained the action after 'being at risk of COPD' and also the follow-up steps. However, substantial adverse effects occurred in subjects with symptoms and being 'not at risk of COPD' or having 'normal spirometry'. Although we did send an explanatory letter, the provided contents were apparently not sufficient. In the practices this led to patient questions over the desk more as we had expected.

We performed the process of clustered-randomization for practices with a patient-managed or a practice-managed condition. In our quality assessment we did not properly define prior exclusion criteria for candidate practices. In the comparative study by Haroon et al. (13) these exclusion criteria were also lacking.

A last limitation is that we are not able to evaluate certain aspects of the procedural quality of the office spirometry as we omitted to register the number of spirometry procedures that had to be discarded due to unacceptable quality.

\section{Recommendations}

\section{General practices}

Integrated COPD primary care is complex and includes careful diagnostic casefinding, targeted population-based screening, and management of symptoms and follow-up. Our recommendation for practice would be that the primary care programmes for chronic conditions like COPD, cardiovascular diseases and diabetes mellitus should not be performed in isolation but in combination. One of 
the reasons is that these conditions have risk factors in common (e.g. smoking, lack of physical activity) and a combined approach may prove to be efficient and more targeted to the person with chronic conditions.

\section{Research}

The advantage of a COPD early detection programme might be that it detects hitherto hidden symptoms that could point towards early stages of COPD. It is unknown what the impact of treatment of COPD that is detected through opportunistic screening is. Further research is needed to evaluate the impact of early detection on management and prognosis.

\section{Conclusion}

The findings of the studies presented in the current thesis allow several conclusions to be drawn with regard to a COPD early detection programme in general practice. First, a targeted population-based screening programme using an active practice-managed approach is an effective method to detect new COPD cases. In our study, it yielded a substantial response rate and overall yield of new COPD diagnoses, both nearly twice as high as opportunistic screening interventions. Such a programme can help reduce COPD underdiagnosis and create more awareness of the disease. The motivation of our newly detected COPD smokers to start a smoking cessation programme was uniquely high, which might be due to the relatively intensive follow-up, involving three practice contacts.

Second, our method can be used to find COPD in low-SES populations. LowSES practices had higher attendance rates, a higher yield of newly found COPD cases, and more current smokers and pack-years. The cost of finding one new COPD diagnosis in these groups was lower than in the moderate- to high-SES practices, but the absolute workload and time expenditure involved in the programme were higher. Low-SES smokers perceive COPD as a self-inflicted disease, which requires carefully balanced smoking cessation counseling to prevent dropout of the patients from the programme. 


\section{References}

1. Murray CJ, Lopez AD. Alternative projections of mortality and disability by cause 1990-2020: Global Burden of Disease Study. Lancet 1997:349:1498-504.

2. Lopez AD, Shibuya K, Rao C. The global burden of COPD: future COPD projections. Eur Respir J 2006; 27: 397-412.

3. Vanfleteren LEGW, Franssen FME, Wesseling G, Wouters EFM. The prevalence of chronic obstructive pulmonary disease in Maastricht, the Netherlands. Resp Med 2012;106:871-874.

4. Bischoff EWMA, Schermer TRJ, Bor H, Brown P, van Weel C, van den Bosch WJHM. Trends in COPD prevalence and exacerbation rates in Dutch primary care. Br J Gen Pract 2009;59:927-933.

5. van Schayck $C P$, van der Heijden FMMA, van den Boom G, Tirimanna $P$, van Herwaarden CLA. Underdiagnosis of asthma: is the doctor or the patient to blame? The DIMCA project. Thorax 2000;55:562-565.

6. Jones RC, Dickson-Spillmann M, Mather MJ, Marks D, Shackell BS. Accuracy of diagnostic registers and management of chronic obstructive pulmonary disease: the Devon primary care audit. Respir Res 2008;9:62.

7. Miravitlles M, de la Roza C, Morera J, Montemayor T, Gobartt E, Martin A, et al. Chronic respiratory symptoms, spirometry and knowledge of COPD among general population. Respir Med 2006;100:1973-1980.

8. Dirven JA, Muris JW, van Schayck CP. COPD screening in general practice using a telephone questionnaire. COPD 2010;7:352-359.

9. Dirven JAM, Tange HJ, Muris JWM, van Haaren KMA, Vink G, van Schayck CP. Early detection of COPD in general practice: patient or practice managed? A randomised controlled trial of two strategies in different socio-economic environments. Prim Care Respir J 2013; 22:331-337.

10. Dirven JAM, Tange HJ, Muris JWM, van Haaren KMA, Vink G, van Schayck CP. Early detection of COPD in general practice: Implementation, workload and socioeconomic status. A mixed methods observational study. Prim Care Respir J 2013;22:338-343.

11. Dirven JA, Moser A, Tange HJ, Muris JW, van Schayck OC. An innovative COPD early detection programme in general practice: evaluating barriers to implementation. NPJ primary care respiratory medicine 2014;24:14005.

12. Bunker J, Hermiz O, Zwar N, Dennis SM. Feasibility and efficacy of COPD case finding by practice nurses. Aust Fam Physician 2009;38:826-30.

13. Haroon S, Adab P, Griffin C, Jordan R. Case finding for chronic obstructive pulmonary disease in primary care. A pilot randomised controlled trial. Brit J Gen Pract 2013;63:e55-e62.

14. Lyngsø AM, Gottlieb V, Backer V, Nybo B, Østergaard MS, Jørgensen HL, Frølich A: Early detection of COPD in primary care: the Copenhagen COPD screening project. COPD 2013; 10:208-215.

15. Ulrik CS, Løkke A, Dahl R, Dollerup J, Hansen G, Cording PH, Andersen KK, TOP study group: Early detection of COPD in general practice. Int $\mathrm{J}$ Chron Obstruct Pulmon Dis 2011;6:123-127.

16. Calverley PM, Nordyke RJ, Halbert RJ, Isonaka S, Nonikov D. Development of a populationbased screening questionnaire for COPD. COPD 2005;2:225-232.

17. Freeman D, Nordyke RJ, Isonaka S, Nonikov DV, Maroni JM, Price D, et al. Questions for COPD diagnostic screening in a primary care setting. Respir Med. 2005;99:1311-1318.

18. Buffels J, Degryse J, Liistro G. Diagnostic certainty, co-morbidity and medication in a primary care population with presumed airway obstruction: the DIDASCO2 study. Prim Care Respir J 2009;18:34-40.

19. Schayck CP van, Loozen JM, Wagena E, et al. Detecting patients at a high risk of developing chronic obstructive pulmonary disease in general practice: cross sectional case finding study. BMJ 2002;324:1370. 
20. Kanervisto M, Vasankari $T$, Laitinen $T$, Heliovaara M, Jousilahti $P$, Saarelainen S. Low socioeconomic status is associated with chronic obstructive airway diseases. Resp Med 2011; 105:1140-1146.

21. Løkke A, Hilberg O, Tønnesen P, Ibsen R, Kjellberg J,Jennum, P. Direct and indirect economic and health consequences of COPD in Denmark: a national register-based study: 1998-2010. BMJ open 2014;4:e004069.

22. Mapel DW, Robinson SB, Dastani HB, Shah H, Phillips AL, Lydick E. The Direct Medical Costs of Undiagnosed Chronic Obstructive Pulmonary Disease. Value in Health 2008; 11:4, 628-636.

23. Hegewald MJ, Crapo RO. Socioeconomic status and lung function. Chest 2007;132: 1608-1614.

24. Dalstra JA, Kunst AE, Geurts JJ, Frenken FJ, Mackenbach JP. Trends in socioeconomic health inequalities in the Netherlands, 1981-1999. Journal of Epidemiology and Community Health 2002;56:927-934.

25. Yin P, Zhang M, Li Y, Jiang Y, Zhao W. Prevalence of COPD and its association with socioeconomic status in China: Findings from China Chronic Disease Risk Factor Surveillance 2007. BMC Public Health 2011;11:586.

26. Nielen MMJ, van der Meer V, Schellevis FG. Evaluatie pilot Preventieconsult cardiometabool risico. Utrecht. NIVEL, 2010.

27. Klein Woolthuis EP, de Grauw WJC, van Gerwen WHEM, van den Hoogen HJM, van de Lisdonk EH, Metsemakers JFM, van Weel C. Yield of opportunistic targeted screening for type 2 diabetes in primary care: the Diabscreen study. Ann Fam Med 2009;7:422-430.

28. Marteau TM. Psychological costs of screening. BMJ 1989;299:527.

29. Halding AG, Heggdal K, Wahl A. Experiences of self-blame and stigmatisation for self-infliction among individuals living with COPD. Scand J Caring Sci 2011;25:100-107.

30. Lindquist G, Hallberg LRM. Feelings of Guilt due to Self-inflicted Disease: A Grounded Theory of Suffering from Chronic Obstructive Pulmonary Disease (COPD). J Health Psychol 2010;15: 456.

31. Odencrants S, Ehnfors M, Grobe S. Living with chronic obstructive pulmonary disease (COPD): Part II. RNs' experience of nursing care for patients with COPD and impaired nutritional status. Scand J Caring Sci 2007;21:56-63.

32. Murray M, Bodenheimer T, Rittenhouse D, Grumbach K. Improving Timely Access to Primary Care: Case Studies of the Advanced Access Model. JAMA 2003;289:1042-1046.

33. Chavannes N, Schermer T, Akkermans R, et al. Impact of spirometry on GPs' diagnostic differentiation and decision-making. Respir Med 2004,98:1124-1130.

34. Lucas AEM, Smeenk FJWM, van den Borne BEEM, Smeele IJM, van Schayck CP. Diagnostic assessments of spirometry and medical history data by respiratory specialists supporting primary care: are they reliable? Prim Care Respir J 2009;18:177-184.

35. Vandevoorde J, Verbanck S, Gijssels L, Schuermans D, Devroey D, De Backer J, Kartounian J, Vincken W. Early detection of COPD: a case finding study in general practice. Respir Med 2007;101:525-530.

36. Stratelis G, Jakobsson P, Molstad S, Zetterstrom O. Early detection of COPD in primary care: screening by invitation of smokers aged 40 to 55 years. Br J Gen Pract 2004;54:201-206.

37. Johannessen A, Omenaas ER, Bakke PS, Gulsvik A: Implications of reversibility testing on prevalence and risk factors for chronic obstructive pulmonary disease: a community study. Thorax 2005;60:842-847.

38. Stanczyk NE, Bolman C, Smit ES, Candel MJJM, Muris JWM, de Vries H. How to encourage smokers to participate in web-based computer-tailored smoking cessation programs: a comparison of different recruitment strategies. Health Education Research 2013; cyt104v1cyt104.

39. Rabe KF, Hurd S, Anzueto A, Barnes PJ, Buist SA, Calverley P. Global strategy for the diagnosis, management, and prevention of chronic obstructive pulmonary disease: GOLD executive summary. Am J Respir Crit Care Med 2007;176:532-555.

40. Bize R, Burnand B, Mueller Y, Rege Walther M, Cornuz J. Biomedical risk assessment as an aid for smoking cessation. Cochrane Database Syst Rev. 2009(19370604). 
41. Wilson JMG, Jungner G. Principles of early disease detection. World Health Organization. Geneva, Public Health Papers 1968;34:27-39.

42. Stead LF, Buitrago G, Preciado N, Sanchez G, Hartmann-Boyce J, Lancaster T. Physician advice for smoking cessation. Cochrane Database Systematic Review 2013;5: CD000165.

43. Pieterse ME, Seydel ER, Vries H de, Mudde AN, Kok GJ. Effectiveness of a minimal contact smoking cessation programme for Dutch general practitioners: a randomized controlled trial. Prev Med 2001;32:182-190.

44. Gorecka D, Bednarek M, Nowiinski A, Pucjinska E, Goljan-Geremek A, Zieliinski J. Diagnosis of airflow limitation combined with smoking cessation advice increases stop smoking rate. Chest 2003;123:1916-1923.

45. Bednarek M, Gorecka D, Wielgomas J, et al. Smokers with airway obstruction are more likely to quit smoking. Thorax 2006;61:869-873.

46. Parkes $G$, Greenhalgh $T$, Griffin $M$, Dent R. Effect on smoking quit rate of telling patients their lung age: the Step2quit randomized controlled trial. BMJ 2008;336:598-600.

47. Zwar NA, Richmond RL. Role of the general practitioner in smoking cessation. Drug Alcohol Rev 2006;25;21-26.

48. Coleman T, Murphy E, Cheater F. Factors influencing discussion of smoking between general practitioners and patients who smoke: a qualitative study. Brit J Gen Pract 2000;50:207-210.

49. Marmot M. Social determinants of health inequalities. Lancet,2005;365:1099-1104.

50. Tinkelman DG, Price DB, Nordyke RJ, Halbert RJ. Misdiagnosis of COPD and asthma in primary care patients 40 years of age and over. $J$ Asthma 2006;43:75-80.

51. Chang J, Mosenifar Z. Differentiating COPD from asthma in clinical practice. J Intensive Care Med 2007;22:300-309.

52. Global Initiative for Chronic Obstructive Lung Disease. Global strategy for diagnosis, management, and prevention of COPD,2014. www.goldcopd.org/uploads/users/files/ GOLD2014Jun11.pdf

53. Miravitlles M, Soriano JB, Garcia-Rio F, et al. Prevalence of COPD in Spain: impact of undiagnosed COPD on quality of life and daily life activities. Thorax 2009;64:863-868.

54. O'Reilly JF, Williams AE, Holt K, Rice L. Defining COPD exacerbations: impact on estimation of incidence and burden in primary care. Prim Care Respir J 2006;15:346-353.

55. Bednarek M, Maciejewski J, Wozniak M, et al. Prevalence, severity and underdiagnosis of COPD in the primary care setting. Thorax 2008;63:402-407.

56. Renwick DS, Conolly MJ. Prevalence and treatment of chronic airways obstruction in adults over the age of 45. Thorax 1996;51:164-168.

57. Brand PLP, Rijcken B, Schouten JP, Koëter GH, Weiss ST, Postma DS. Perception of airway obstruction in a random population sample: Relationship to airway hyperresponsiveness in the absence of respiratory symptoms. Am Rev Respir Dis 1992;146:396-401.

58. Festinger L. A theory of cognitive dissonance. Stanford, Calif.: Stanford University Press, 1962.

59. US Preventive Services Task Force. Screening for chronic obstructive pulmonary disease using spirometry: U.S. preventive services task force recommendation statement. Ann Interne Med 2008;148:529-534.

60. Qaseem A, Wilt TJ, Weinberger SE, Hanania NA, Criner G, van der Molen T. Diagnosis and management of stable chronic obstructive pulmonary disease: a clinical practice guideline update from the American College of Physicians, American College of Chest Physicians, American Thoracic Society, and European Respiratory Society. Ann Intern Med 2011;155: 179-191.

61. De Marco, R, Verlato, G, Zanolin, E, et al. Nonresponse bias in EC Respiratory Health Survey in Italy.Eur Respir J 1994;7,2139-2145. 

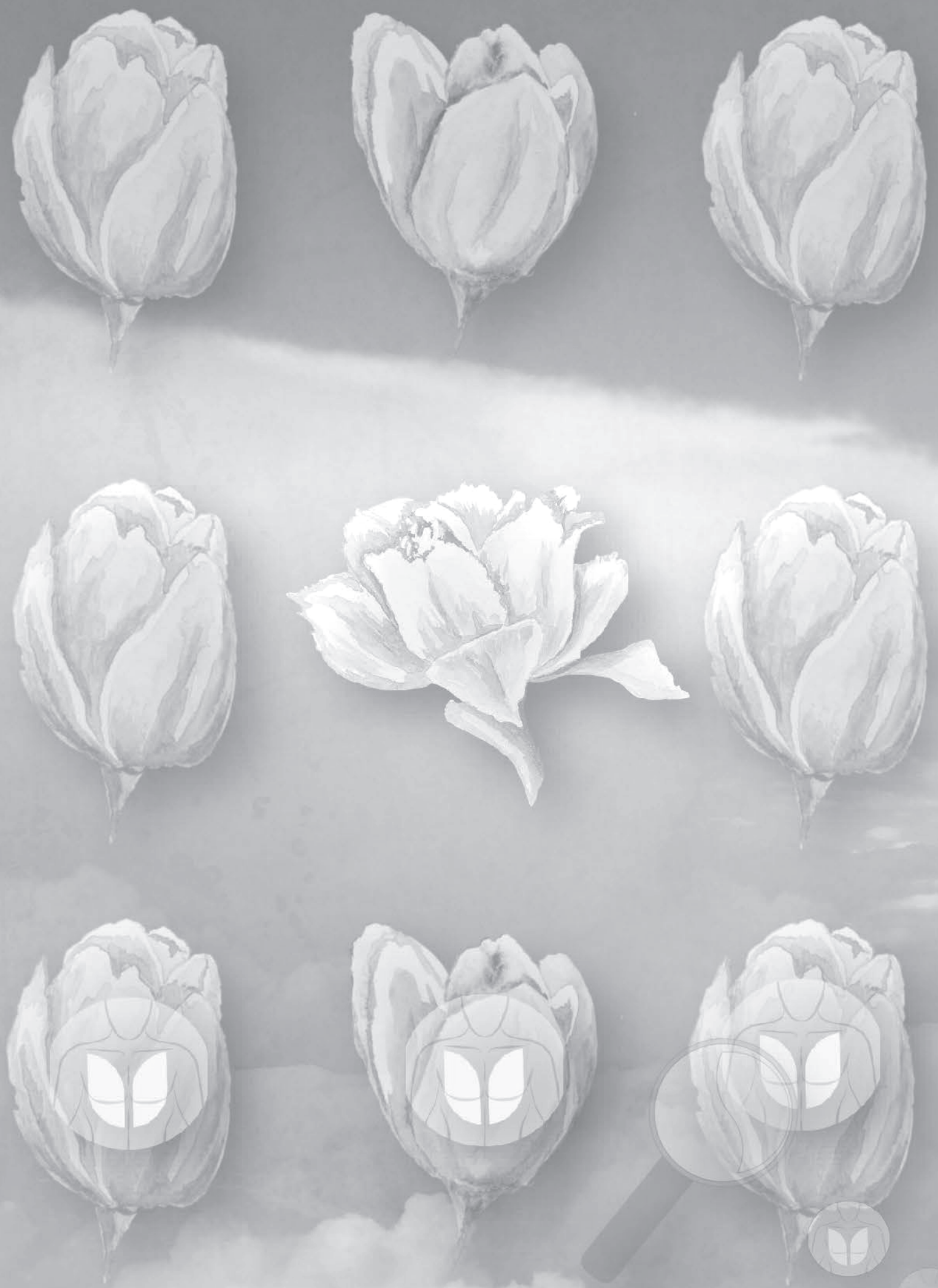


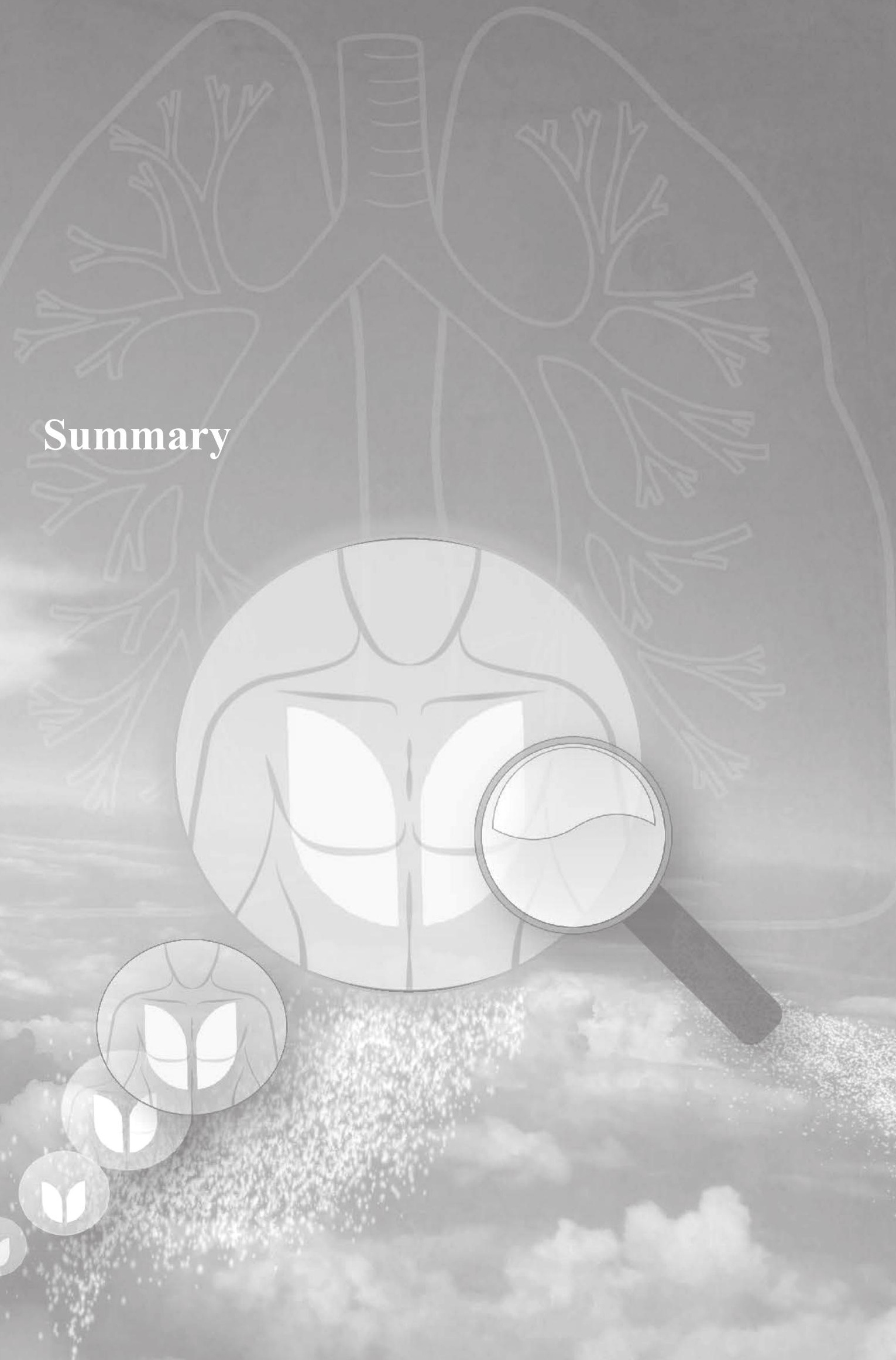




\section{Summary}

The main aim of this thesis was to develop strategies for early detection of COPD. The studies in this thesis were carried out in primary care practices.

Chapter 1 is a general introduction to the studies presented in this thesis. It describes the background and the research aims of this dissertation. The differences between opportunistic and targeted population-based screening methods are discussed.

Chapter 2 reports a cross-sectional observational study in two general practices with approximately 4200 patients at the time of assessment. The aim of this survey was to study the feasibility of detection of undiagnosed COPD patients in the general practice population. During two weeks all persons between 40-75 years old were contacted by a call centre. During a telephone interview the validated Respiratory Health Screening Questionnaire (RHSQ) was administered to every respondent. Based on the score on this instrument, respondents were classified as having a low, moderate or high risk to have or to develop COPD. In patients with medium and high risk for COPD, spirometry was performed by two experienced, certified nurses. The results of the telephone interview and spirometric findings, were assessed by the attending GP who gave the final clinical diagnosis. 1032 persons were reached by telephone of whom 813 answered the questions. $49.2 \%$ of them were smokers, their average number of pack years was $17.9(\mathrm{SD}=17)$. Spirometry and analysis by the GP showed that in the medium risk group $15.7 \%$ had previously undiagnosed COPD. In the high risk group $39.6 \%$ had COPD. The number of undiagnosed COPD patients in the general practice population was considerable. It was concluded that early detection of COPD is possible and feasible in moderate and high risk groups using a call centre. Although this strategy is effective, its implementation is hampered by the high costs that accompany this approach. This led us to presume that an alternative approach utilising written questionnaires instead of telephone surveys could be more feasible.

Chapter 3 reports on an alternative strategy of early detection of COPD through targeted population-based screening using questionnaires in a primary care setting. Two different approaches were compared and assessed on their effectiveness, while taking different socioeconomic status (SES) settings into account. The RHSQ was distributed to all participants. In the so-called practicemanaged condition, the primary care practice was responsible for the whole procedure. In contrast, in the patient-managed condition patients were responsible for calculating their own RHSQ risk score and applying for a spirometry test. Randomisation took place on practice level and a stratification for socioeconomic setting was applied. The primary outcome measure was the rate of new COPD diagnoses after screening. In the practice-managed condition 
more new COPD patients were detected $(36 \%)$ than in the patient-managed condition (18\%). In low-SES practices more high-risk patients were found (16\%) than in moderate-high SES practices (9\%). These findings implicate that in a standard Dutch practice (2350 patients) the yield would be 8.9 new COPD diagnoses, which is a $20 \%$ increase of known cases. The practice-managed approach was the most effective and, moreover, associated with lower cost per new COPD diagnosis.

We concluded that the practice-managed approach of this targeted screening procedure shows a substantial yield of new COPD diagnoses for both low-SES and moderate-high SES practices.

Chapter 4 presents an observational study that aimed to measure the impact of the practice-managed approach on primary care workload, and to assess the influence of the socioeconomic status (SES) and detected barriers on the degree of implementation of this strategy. The RHSQ was posted in a period of 3 months to all persons that were at that time 45,55 , or 65 years of age (one age group per month). After the questionnaires had been returned the practices calculated the risk for COPD for each individual. Patients at high risk were invited for spirometry and a consultation at the practice. The general practitioner used the spirometric results and a consultation to establish a clinical diagnosis. Qualitative and quantitative data on workload, cost and barriers were recorded. Ten practices were able to collect 293 COPD risk tests $(35.3 \%$ of a total of 831 distributed). Participants from low SES practices responded better $(40.8 \%)$ than from moderate-high SES practices (30.5\%). In low SES practices, $17.9 \%$ of the tests indicated high risk; in moderate-high SES practices, $16.1 \%$. In total nine patients $(23 \%)$ were newly diagnosed with COPD in the end. The healthcare providers' extra workload averaged 18.5 hours during 3 months for one standard practice. The cost for this survey programme (three age groups in three months) was on average $€ 520$ for low SES practices and $€ 398$ for moderate-high SES practices. All healthcare providers affirmed that the extra workload in this targeted screening model was acceptable and feasible when finances would have been compensated. Workload, reimbursement, low-SES and ethnic diversity were identified as barriers to implementation. We concluded that early detection of COPD is feasible in daily primary care. In moderate-high SES practices the workload and costs for detecting COPD were less than in low SES practices.

Chapter 5 presents a qualitative study in which the barriers to implementation of targeted screening from the model in chapter 4 are further assessed through indepth interviews with health care providers. These barriers concern structural obstacles in the organization of the care programme like extra workload and costs. Furthermore patient-related factors were identified by care providers: low socioeconomic status (SES) and ethnic minorities. Care providers in moderate 
to high SES practices show differing attitudes from their colleagues in lower socio-economic practices regarding outcome expectancy, self-efficacy and attitude towards their low SES patients. In their perception this patient subgroup requires much extra support to arrive at successful stop smoking attempts.

In Chapter 6 the findings of this dissertation are discussed using a broader perspective. Different aspects of COPD early detection were considered, such as the risk of COPD, the yield of new COPD diagnoses, the workload for the healthcare provider and the obstacles to implementation of the programme. In addition, the strengths and limitations of the studies in this thesis are presented and an overall conclusion is given. 

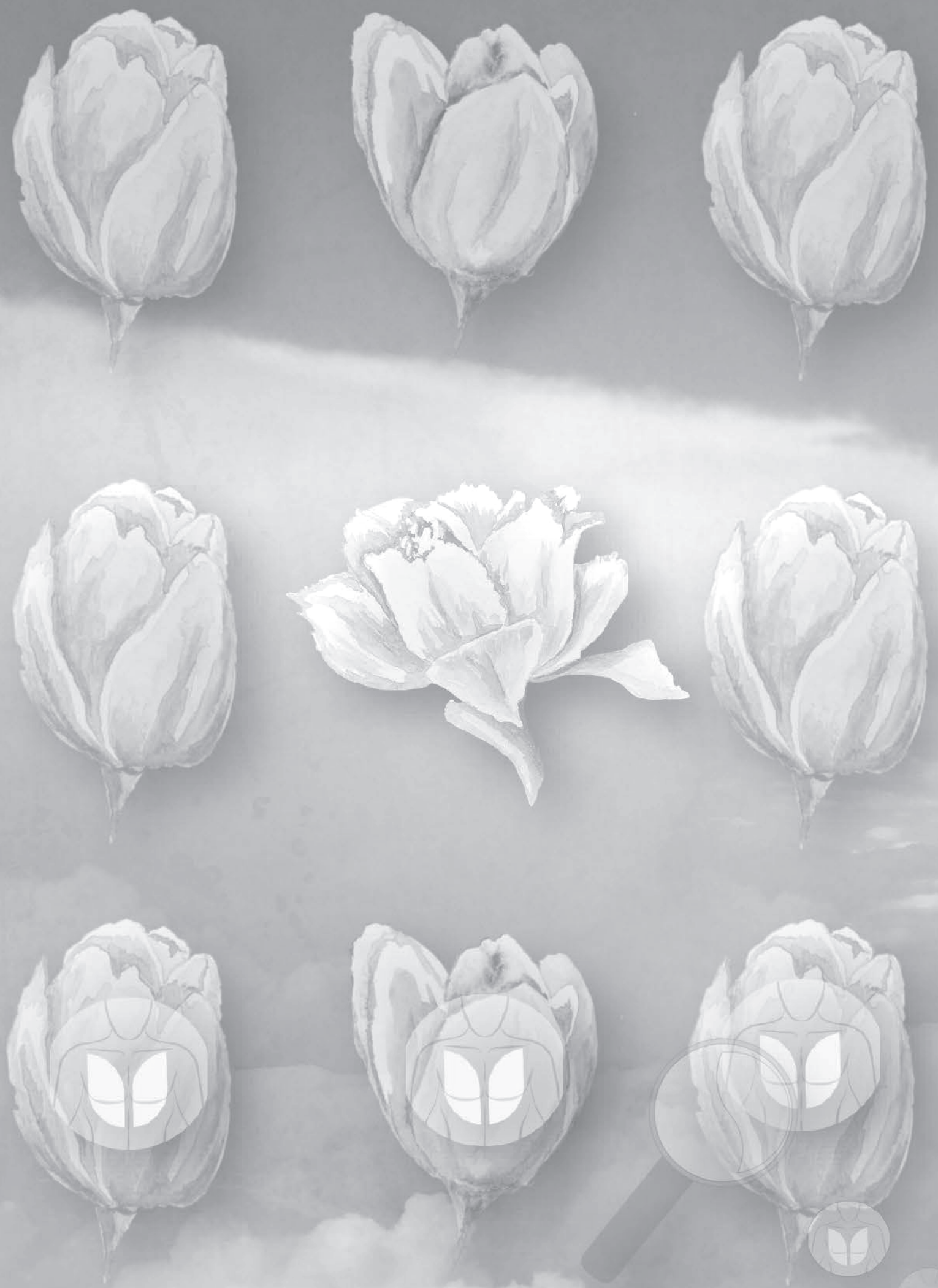


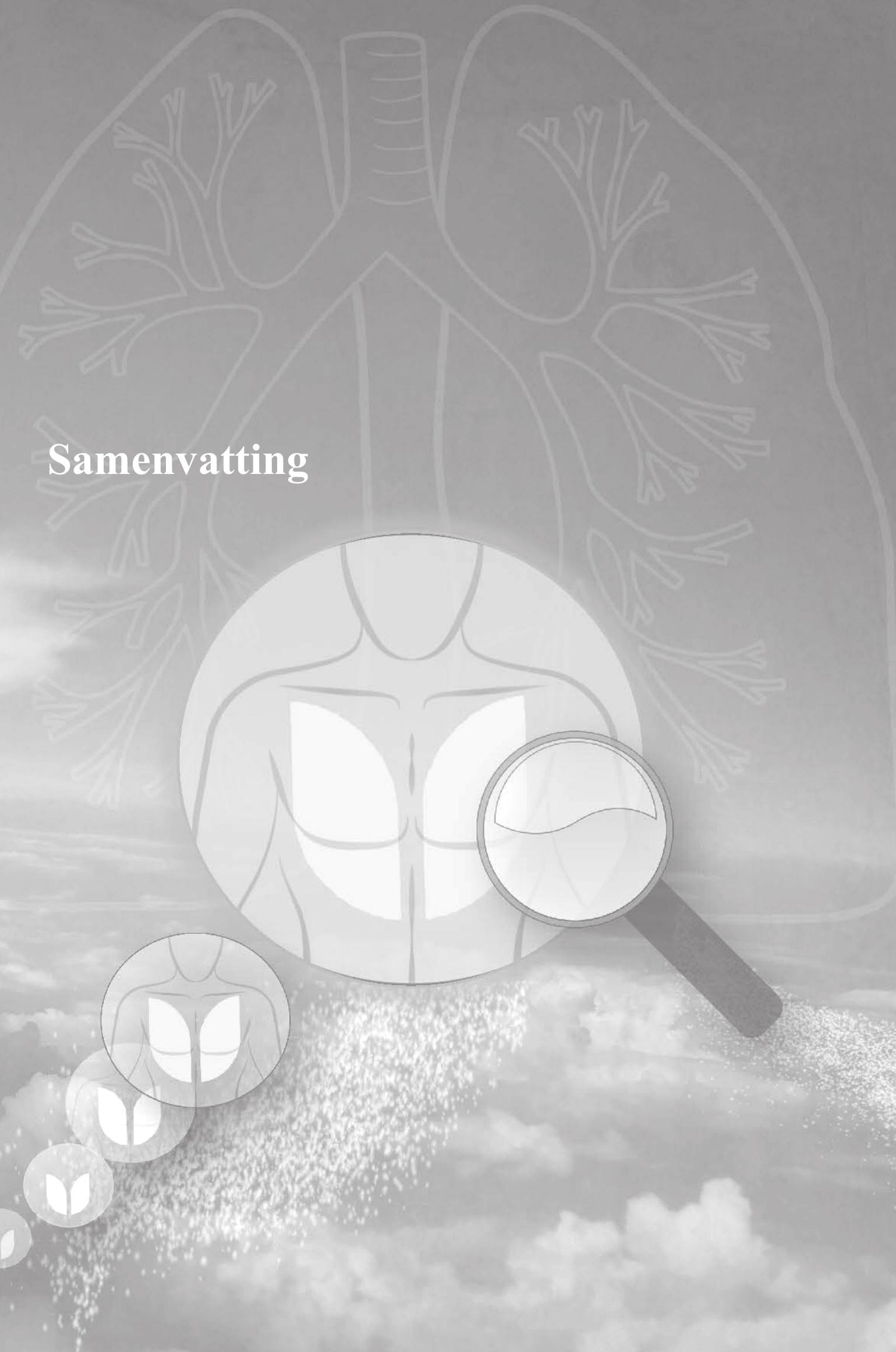




\section{Samenvatting}

Het voornaamste doel van het werk waarop dit proefschrift is gebaseerd was het ontwikkelen van strategieën voor de vroegtijdige opsporing van COPD. De in dit proefschrift besproken studies werden uitgevoerd in huisartsenpraktijken.

Hoofdstuk 1 vormt een algemene inleiding op de in dit proefschrift besproken studies. Hierin worden de achtergrond en de onderzoeksdoelen van het proefschrift besproken, alsmede de verschillen tussen opportunistische en gerichte screeningsmethoden voor bevolkingsonderzoek.

In hoofdstuk 2 wordt verslag gedaan van een observationeel crossectioneel onderzoek uitgevoerd in twee huisartsenpraktijken, met ten tijde van het onderzoek ca. 4200 patiënten. Doel van dit onderzoek was om te bepalen of het haalbaar is patiënten met nog niet gediagnosticeerde COPD in de praktijkpopulatie op te sporen. Gedurende twee weken werden alle patiënten in de leeftijd van 40-75 jaar gebeld door een callcenter. Tijdens een telefoongesprek werd met elke respondent een gevalideerde vragenlijst doorgenomen, de Respiratory Health Screening Questionnaire (RHSQ). Op basis van de score op dit instrument werd vastgesteld of de respondenten een laag, matig of hoog risico hadden op COPD. Bij degenen met een matig of hoog risico op COPD werd vervolgens door twee ervaren en gecertificeerde verpleegkundigen een spirometrie uitgevoerd. De resultaten van het telefonische interview en de spirometrie werden beoordeeld door de behandelend huisarts, die de definitieve klinische diagnose stelde. Telefonisch konden 1032 personen worden bereikt, van wie er 813 de vragen beantwoordden. Van hen rookte $49,2 \%$, met een gemiddeld aantal pakjesjaren van $17,9(\mathrm{SD}=17)$. Uit de spirometrie en de beoordeling door de huisarts bleek dat er in de groep met matig risico bij $15,7 \%$ sprake was van niet eerder gediagnosticeerde COPD. In de groep met hoog risico had 39,6\% COPD. Het aantal niet gediagnosticeerde patiënten met COPD in de praktijkpopulatie bleek aanzienlijk te zijn. Geconcludeerd werd dat vroegtijdige opsporing van COPD bij groepen met matig of hoog risico met behulp van een callcenter mogelijk en haalbaar is. Hoewel dit een effectieve strategie is, wordt de implementatie ervan belemmerd door de hoge kosten die eraan verbonden zijn. Wij veronderstelden dat een alternatieve aanpak op basis van papieren vragenlijsten in plaats van telefonische benadering beter haalbaar zou kunnen zijn.

In hoofdstuk 3 wordt een onderzoek besproken naar een alternatieve strategie voor de vroegtijdige opsporing van COPD door middel van doelgericht bevolkingsonderzoek met behulp van vragenlijsten in een eerstelijns omgeving. Hierbij werden twee benaderingen vergeleken op effectiviteit, waarbij rekening werd gehouden met de sociaal-economische status (SES) van de deelnemers. Alle deelnemers kregen de RHSQ toegestuurd. Bij de zogenaamde praktijk- 
gestuurde benadering was de huisartsenpraktijk verantwoordelijk voor de gehele procedure, terwijl bij de patiëntgestuurde benadering de patiënten hun eigen RHSQ-risicoscore bepaalden en eventueel een spirometrietest aanvroegen. De deelnemers werden op praktijkniveau gerandomiseerd, en gestratificeerd op sociaal-economische status. De primaire uitkomstmaat was het percentage nieuwe COPD-diagnoses na de screening. Met de praktijkgestuurde benadering werden meer nieuwe COPD-patiënten ontdekt $(36 \%)$ dan met de patiëntgestuurde benadering (18\%). Voorts werden in praktijken met een lage SES signatuur meer patiënten met een hoog risico gevonden (16\%) dan in praktijken met een gemiddelde tot hoge SES $(9 \%)$. Deze resultaten impliceren dat in een standaard Nederlandse huisartsenpraktijk (met 2350 patiënten) deze strategie 8,9 nieuwe COPD-diagnoses zou opleveren, een toename van $20 \%$ ten opzichte van de bekende gevallen. De praktijkgestuurde benadering bleek de meest effectieve en ging bovendien gepaard met lagere kosten per nieuwe COPDdiagnose. Geconcludeerd werd dat de praktijkgestuurde vorm van deze doelgerichte screeningsstrategie leidde tot een aanzienlijke opbrengst aan nieuwe COPD-diagnoses, zowel in praktijken met lage SES als in praktijken met gemiddeld tot hoge SES.

In hoofdstuk 4 wordt een observationeel onderzoek besproken dat als doel had te bepalen welke impact de praktijkgestuurde benadering heeft op de werklast in de eerstelijns zorg, om de invloed van de SES en om eventuele knelpunten bij de implementatie van deze strategie te bepalen. Hiertoe werd over een periode van drie maanden de RHSQ vragenlijst toegestuurd aan alle personen die ten tijde van het onderzoek 45, 55 of 65 jaar oud waren (één leeftijdsgroep per maand). Op basis van de teruggestuurde vragenlijsten berekenden de praktijkmedewerkers voor elke deelnemer het risico op COPD. Patiënten met een hoog risico werden uitgenodigd voor spirometrie en een consult in de praktijk. De huisarts bepaalde op basis van de resultaten van spirometrie en een spreekuurconsult de klinische diagnose. Kwalitatieve en kwantitatieve gegevens over werklast, kosten en knelpunten werden bijgehouden. Door de tien deelnemende praktijken werden 293 vragenlijsten verzameld $(35,3 \%$ van de in totaal 831 verstuurde vragenlijsten). De respons was hoger onder patiënten van praktijken met een lage SES $(40,8 \%)$ dan onder patiënten van praktijken met gemiddelde tot hoge SES signatuur $(30,5 \%)$. In de praktijken met lage SES signatuur bleek uit $17,9 \%$ van de tests dat er sprake was van een hoog risico op COPD, tegen $16,1 \%$ in praktijken met gemiddelde tot hoge SES. Uiteindelijk werden er in totaal $9(23 \%)$ nieuwe COPD-diagnoses gesteld. De extra werklast voor de zorgverleners in één standaardpraktijk bedroeg gedurende de drie maanden gemiddeld 18,5 uur. De kosten van het screeningsprogramma (drie leeftijdsgroepen in drie maanden) bedroegen voor praktijken met lage SES gemiddeld $€ 520$, en voor praktijken met gemiddelde tot hoge SES $€ 398$. Alle 
deelnemende zorgverleners bevestigden dat de extra werklast bij deze doelgerichte screeningsstrategie aanvaardbaar en haalbaar was, mits hiervoor financiële compensatie kon worden verkregen. Als knelpunten voor de implementatie werden genoemd de werklast, de vergoeding, lage SES en etnische diversiteit. Geconcludeerd werd dat vroegtijdige opsporing van COPD in de dagelijks huisartsenpraktijk haalbaar is. De met de opsporing gepaard gaande werklast en kosten waren lager in praktijken met een gemiddelde of hoge SES dan in praktijken met een lage SES.

In hoofdstuk $\mathbf{5}$ worden de resultaten besproken van een kwalitatief onderzoek waarbij de barrières die implementatie van doelgerichte screening op basis van het in hoofdstuk 4 gepresenteerde model in de weg staan, nader bestudeerd door middel van diepte-interviews met zorgverleners. Bij deze barrières gaat het om structurele obstakels in de organisatie van het screeningsprogramma, zoals de extra werklast en de kosten. Daarnaast noemden de zorgverleners patiëntgerelateerde factoren als lage SES en etnische groepen. De zorgverleners in praktijken met een gemiddelde tot hoge SES signatuur hadden lagere verwachtingen en toonden minder vertrouwen in hun lage SES patiënten dan de zorgverleners in lage SES praktijken. Volgens eerst genoemde groep hadden de patiënten met lage SES bijvoorbeeld veel meer extra ondersteuning nodig om succesvol een stoppen met roken poging te ondernemen.

In hoofdstuk 6 worden de bevindingen van de in dit proefschrift besproken studies in een breder perspectief geplaatst. Hierbij worden diverse aspecten van de vroegtijdige opsporing van COPD besproken, zoals het risico op COPD, de opbrengst aan nieuwe COPD-diagnoses, de werklast voor de zorgverleners en de obstakels die implementatie van het screeningsprogramma bemoeilijken. Voorts worden de sterke en zwakke aspecten van de deelstudies van het proefschrift besproken en zijn algemene conclusies geformuleerd. 

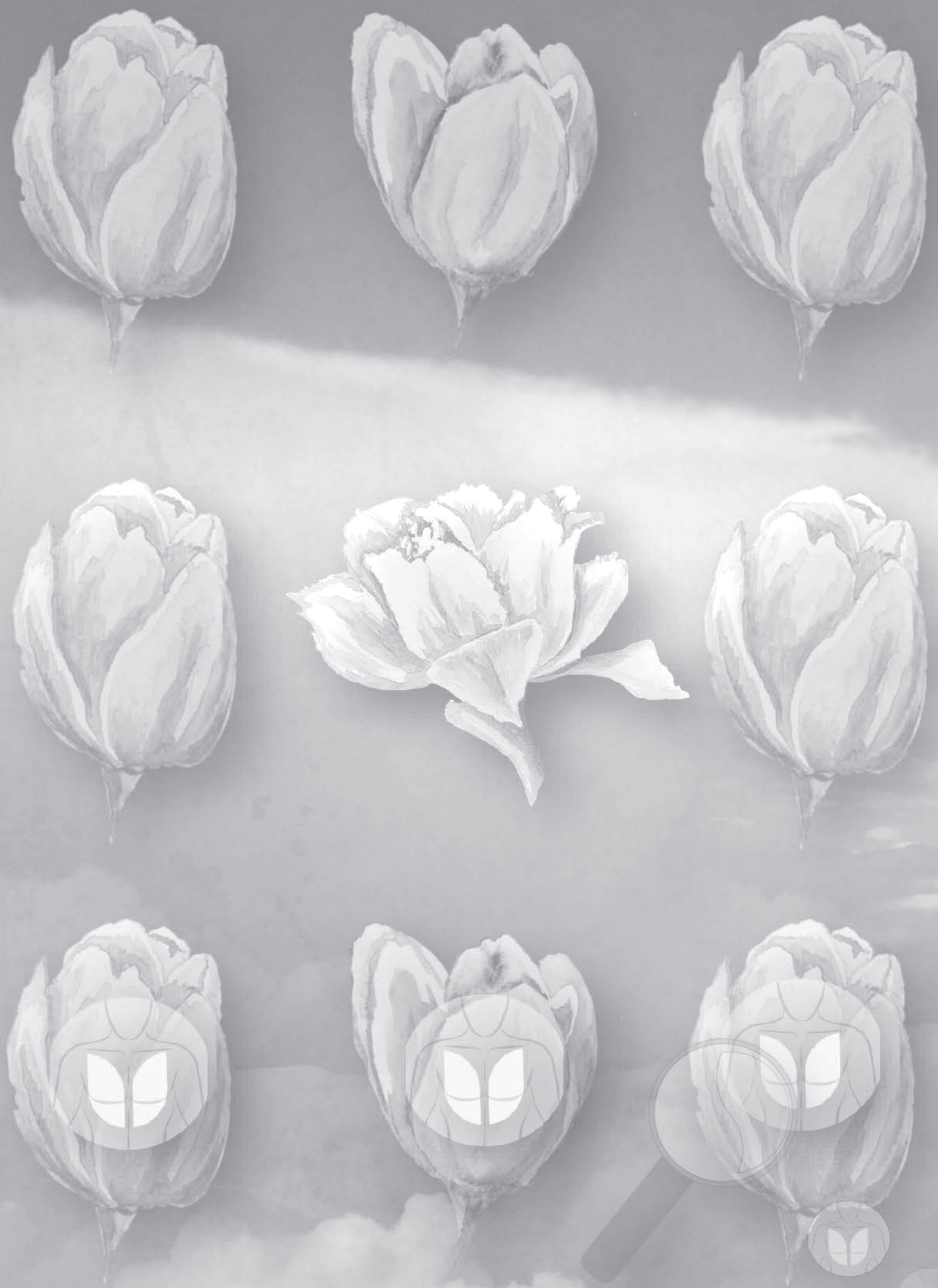


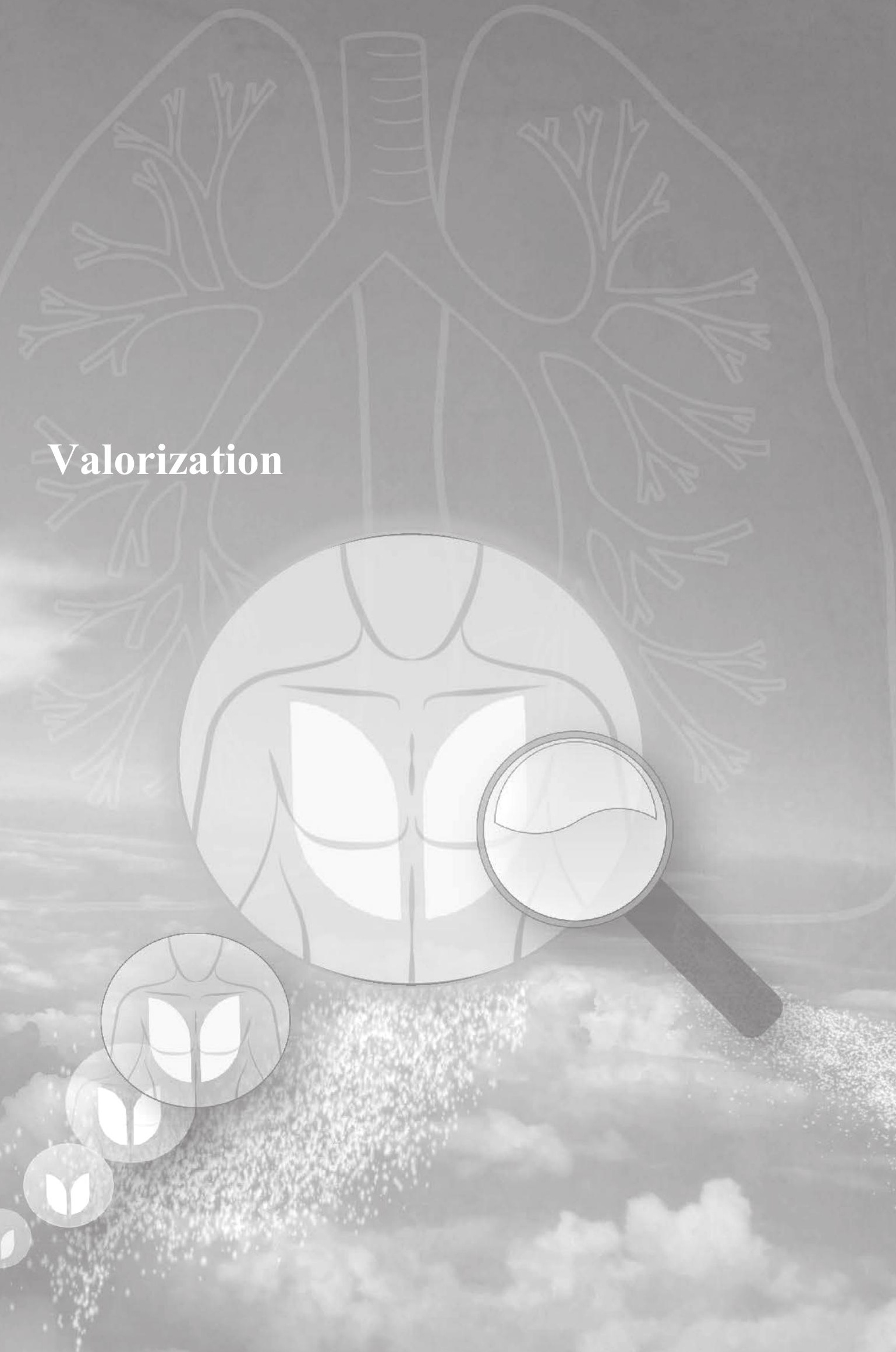




\section{Valorization}

This chapter will discuss the current findings of this thesis in the light of the societal and economic impact as well as innovative concepts for future health care. It describes the activities resulting from the empirical studies in this thesis, in relationship to an array of target groups. The valorization potential of this thesis is presented, together with barriers and risks that need to be overcome.

\section{Relevance}

The results of the studies described in this thesis are of societal relevance. COPD is a leading cause of morbidity and mortality worldwide and results in substantial social and economic burden, which has been increasing in the last decade and will continue to do so in the upcoming years. (1) There is considerable debate about the prevalence and its inter-practice variation of chronic obstructive pulmonary disease (COPD) in the Netherlands. The existing underdiagnosis of the disease became clear when population-based studies showed prevalence figures two to three times higher than those found in general practice registry studies. $(2,3)$ Our study confirms this fact of underdiagnosis.

Data obtained from earlier COPD casefinding studies were mostly based on inclusion criteria as the presence of risk factors and chronic respiratory symptoms. $(4,5,6)$ Some studies showed that more than half of the respondents with respiratory symptoms had not previously consulted a health care provider. $(7,8,9)$ Compared to the symptoms all participants of 40 till 70 years age groups reported when being asked in our questionnaire, many of them had failed to report their respiratory symptoms during normal clinical consultation. This suggests that patients lack awareness and knowledge about the disease.(chapter 3)

Early diagnosis of COPD is relevant both for the prevention of disease progression and for its treatment. The studies in this thesis showed evidence that more COPD patients can be detected through targeted population-based screening as compared to usual care (chapters 2 and 3 ), and that the new early detection programme for COPD has achieved that patients became more prepared to actively disclose information about their symptoms and risk factors. In this thesis we made use of the four stage early detection model (chapter 4) to conduct our studies. We provided the Prevention Consultation programme as an exemplary format of script for usage by health care providers that are responsible for screening and prevention in the general practices. (10) 


\section{Target groups}

The results presented in this thesis might be of relevance to several societal groups.

The first and most important group are the patients themselves. One of the most important goals is to raise patients' awareness of having respiratory symptoms, in order to detect patients at risk of COPD. If all patients in the age of 40 to 70 years old would receive from their own doctor a COPD Detection Questionnaire accompanied with an explanatory letter (chapter 3 ) then a considerable amount of them would feel inclined to respond. This way of extensive information dissemination might be an effective way to promote patients' personal preventive activities. The Dutch Lung Foundation (www.longfonds.nl) is an important patients' association promoting the interests of patients with chronic lung disease by providing information and advice, and sharing experiences. On their website they introduced the online COPD risk test from 2010 onwards. The added success of their support by means of multiple mass campaigns, such as the distribution of flyers and television commercials to our programme, is evident.

The second group is that of healthcare professionals who are employed in general practices and are responsible for conducting a COPD early detection programme. Applying the early detection method may enable them to improve the care for their patients as a prevention activity. This is done by means of answering specific questions, motivating new (most early-stage) COPD patients to stop smoking and helping them adhere to other therapeutic recommendations. Moreover, screenees at low and medium risk for COPD are informed about their symptoms, weight, physical activities and quit smoking interventions. Because of spirometry underutilization in general practices more spirometric tests are needed. Minimization of COPD underdiagnosis in the Dutch general practices will result in more known COPD patients being eligible for follow-up and treatment in an integrated chronic care model.

Thirdly, the results and conclusions of the COPD early detection programme is of importance to the national Boards and Colleges of professionals. The Dutch College of General Practitioners and their working-group on COPD have been informed about our results and will take our findings into account regarding the Dutch COPD guideline for GPs.(11) In 2015, the most recent COPD guideline already recommended a method for COPD early detection for the first time. Furthermore, it concluded that the group of current smoking patients with a chronic cough should have direct access to spirometry in the GPs office.

A fourth societal group will be the medical insurance companies. The importance of regional multidisciplinary care groups for the implementation of COPD management programmes is evident. Reimbursement of the costs of regional 
chronic COPD care is being negotiated with medical insurance companies and could be arranged in a bundled payment system. Early detection helps to identify more new cases and hence more exacerbations could be prevented or detected at an earlier phase, which will contribute to the reduction of the burden of the disease.(12) Prevention of exacerbations is extremely important from an economic perspective, as exacerbations generate the majority of costs due to the use of health care services. (13)

The extra workload of a COPD early detection programme in general practice requires extra cost. Dutch insurance companies are now inclined to reimburse the cost of COPD early detection programme in a preparatory module as a part of a bundled payment system in the integrated chronic care model.

\section{Innovative activities}

Several of the activities we studied have proven successful in developing an early detection programme for COPD.

In this thesis the COPD Respiratory Health Screening Questionnaire (RHSQ) takes a central place for COPD early detection. On the website of the Dutch Lung Foundation is the COPD risk test used and has been send back since the year 2010 already 550,000 times. With this result the RHSQ seems to be relevant to Dutch people as being one of the most successful questionnaires for preventive purposes.

An innovative aspect within our early detection programme, is the concept of targeted screening for COPD in general practice. First, the COPD detection questionnaire is posted to all so called healthy persons from 40 till 70 years old. With the results a high risk group can be identified. We call it targeted screening because only the respondents with a relevant risk for COPD, as indicated by their score on the questionnaire, are further evaluated for the presence of COPD in the GP-practice.

After participation in the early detection programme the new COPD patients have received their correct diagnosis earlier than would have occurred during usual clinical care. Subsequently exacerbations can be detected earlier, allowing the right therapy to be administered. Possibly a beneficial effect on health care costs could be presented as there are indications that the direct healthcare costs are much higher for undetected COPD patients than for known COPD patients. (14)

Moreover, stop-smoking intervention can start earlier. Since stop-smoking interventions are an important condition of screening programmes from the point of view of public health, these results are promising. 
Implementation of our approach in a busy GP practice could lead to high burden on health care providers. If they would experience a high or peak workload during the three months of the early detection programme they can make use of specific services for their programme activities. These specific services can exist of supportive actions by a specialized agency, such as compiling a digital mailing list from the electronic medical records and posting questionnaires, structuring the work-up protocol of the programme script, installing and explaining the digital risk tool and performing extra spirometries in a limited time period. However, reimbursement for this support is not in place and still needs negotiation with healthcare insurance companies.

\section{Future directions}

Developments for future implementation that can be seen as spin-offs of our research.

The effects of early detection activities that we found show it is good to establish future directions after designing innovative products for the benefit of target groups. In addition to targeted screening we can identify specific patient target groups at high risk who require immediate spirometry in the context of opportunistic screening (casefinding). We might identify a target group of current smokers with chronic cough; current smokers in low SES groups or patients with comorbidities as cardiovascular disease. More research is needed to identify new target groups. The Dutch COPD guideline might need to be adjusted to include a casefinding programme for persons at high risk of COPD.

Since we know that respondents are likely to use the internet and respond to web-based questionnaires, we could also expect them to visit websites that are recommended to them in a targeted way. The effect of improving education by websites could be to increase the number of respondents. According to recent literature it is possible to integrate a web-based COPD patient self-management support application into the current primary care disease management process. (15) This might be a reason to develop more extensive web-based early detection applications. In cooperation with the Dutch Lung Foundation and the Dutch College of General Practitioners, a Personal Health Check has recently been developed, which includes web-based COPD and cardiovascular risk (CVR) detecting questionnaires.

In the Netherlands, assessment of the implementation of the early detection programme can be successful, when it is included in a 'three-step integrated chronic care_model'. Doctors have pointed out that prior reassessment in the practice registration of all known respiratory diagnoses (first step) and early detection of unknown COPD diagnoses (second step) should precede 
participation in an integrated chronic care programme for COPD as follow-up (third step). 


\section{References}

1. Lopez AD, Shibuya K, Rao C. The global burden of COPD: future COPD projections. Eur Respir J 2006;27:397-412.

2. Vanfleteren LEGW, Franssen FME, Wesseling G, Wouters EFM. The prevalence of chronic obstructive pulmonary disease in Maastricht, the Netherlands. Resp Med 2012; 106: 871-874.

3. Bischoff EWMA, Schermer TRJ, Bor H, Brown P, van Weel C, van den Bosch WJHM. Trends in COPD prevalence and exacerbation rates in Dutch primary care. Br J Gen Pract 2009;59: 927-933.

4. Buffels J, Degryse J, Heyrman J, Decramer M. Office spirometry significantly improves early detection of COPD in general practice: the DIDASCO Study. Chest Journal 2004;125: 1394-1399.

5. Geijer RMM. Detection of COPD in smokers (Thesis). Utrecht, The Netherlands: Utrecht Medical Center; 2006.

6. Vandevoorde J, Verbanck S, Gijssels L, Schuermans D, Devroey D, De Backer J, Kartounian $\mathrm{J}$, Vincken W. Early detection of COPD: a case finding study in general practice. Respir Med 2007;101:525-530.

7. Stratelis G, Jakobsson P, Molstad S, Zetterstrom O. Early detection of COPD in primary care: screening by invitation of smokers aged 40 to 55 years. Br J Gen Pract 2004;54:201-206.

8. Bednarek M, Maciejewski J, Wozniak M, et al. Prevalence, severity and underdiagnosis of COPD in the primary care setting. Thorax 2008;63:402-407.

9. Renwick DS, Conolly MJ. Prevalence and treatment of chronic airways obstruction in adults over the age of 45. Thorax 1996;51:164-8.

10. Preventieconsult COPD. Pilot COPD Prevention Consultation. Dutch College of General Practitioners, Utrecht 2012.

11. Snoeck-Stroband JB, Schermer TRJ, Van Schayck CP, Muris JW, Van der Molen T, In 't Veen JCCM, Chavannes NH, Broekhuizen BDL, Barnhoorn MJM, Smeele I, Geijer RMM, Tuut MK. NHG-Werkgroep Astma bij volwassenen en COPD. NHG-Standaard COPD. Huisarts Wet 2015;58:198-211.

12. Løkke A, Hilberg O, Tønnesen P, Ibsen R, Kjellberg J,Jennum, P. Direct and indirect economic and health consequences of COPD in Denmark: a national register-based study: 1998-2010. BMJ open 2014;4:e004069.

13. Sullivan SD, Ramsey SD, Lee TA. The economic burden of COPD. Chest 2000;117(2 Suppl): 5S-9S.

14. Mapel DW, Robinson SB, Dastani HB, Shah H, Phillips AL, Lydick E. The Direct Medical Costs of Undiagnosed Chronic Obstructive Pulmonary Disease. Value in Health 2008;11:4:628-636.

15. Voncken-Brewster $V$, Tange $H$, Moser A, Nagykaldi $Z$, de Vries $H$, van der Weijden $T$. Integrating a tailored e-health self-management application for chronic obstructive pulmonary disease patients into primary care: a pilot study.BMC Fam Pract 2014;15:4. 

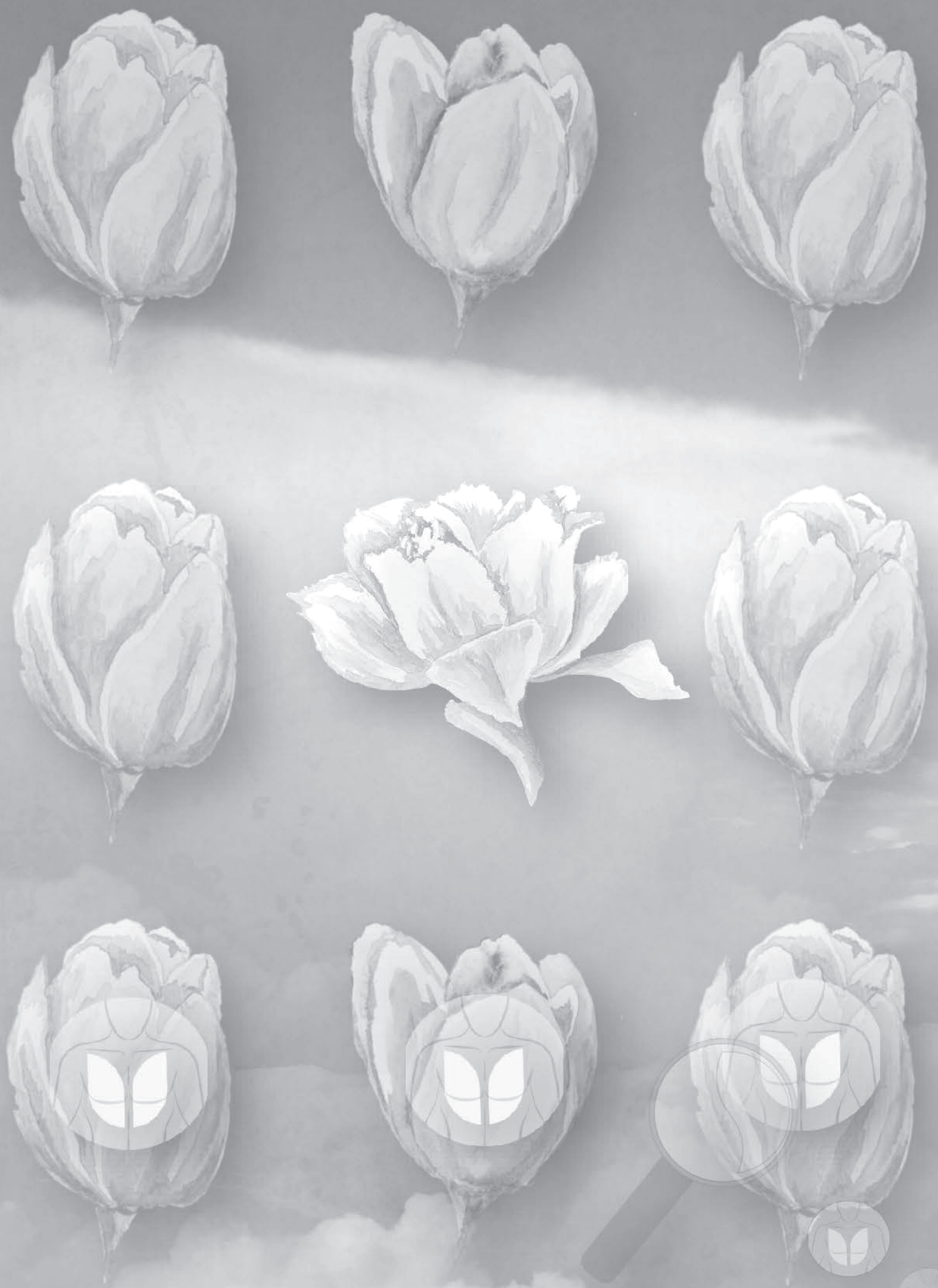


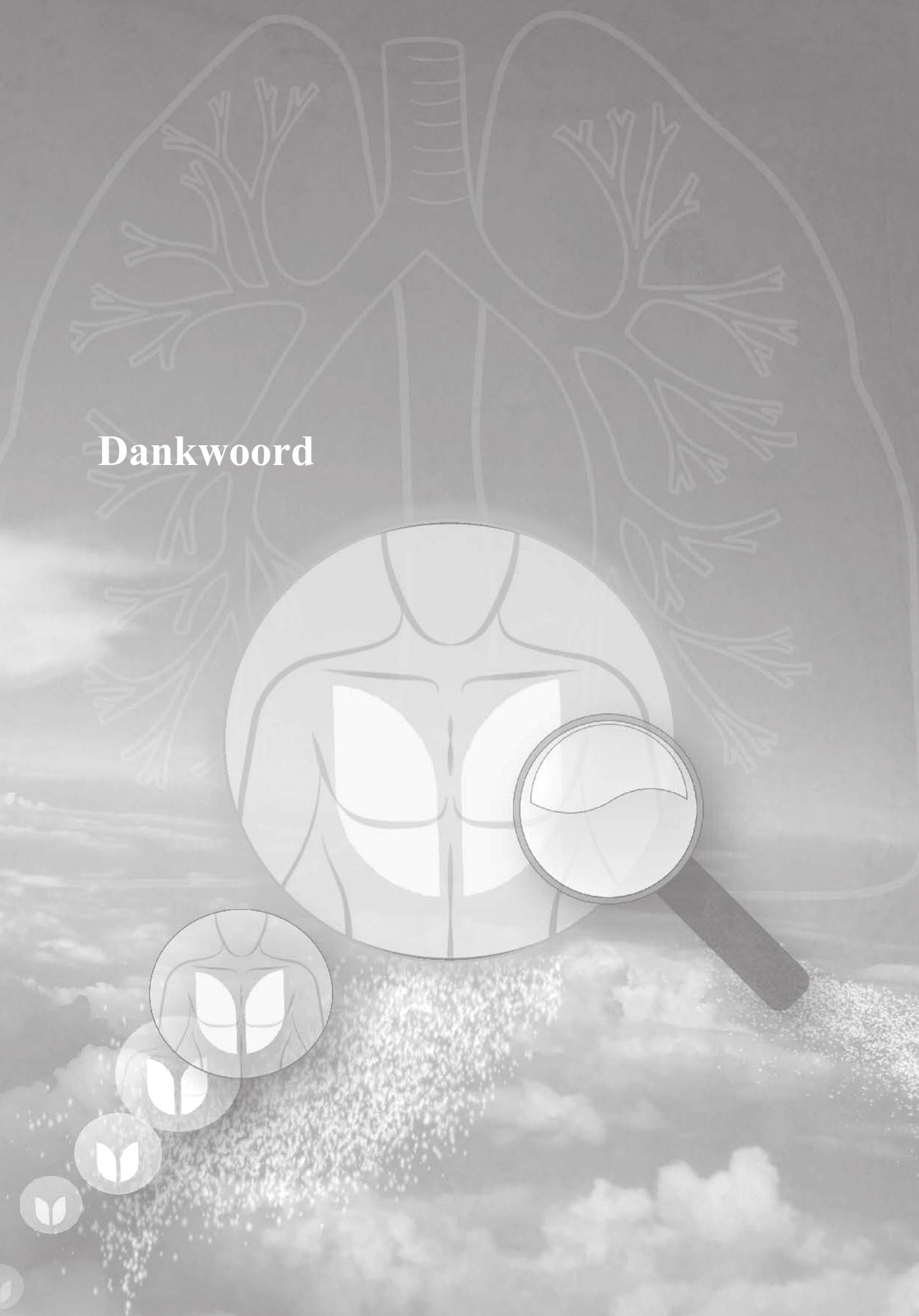




\section{Dankwoord}

Mijn vader is voor mij in zijn rol als pionier een voorbeeld geweest; fijngevoelig maar geen watje; openhartig en hield van het woord. Pioniers werken aan de verbetering van een noodzakelijke verandering; 'als het niet kan zoals het moet, dan moet het zoals het kan'. Dit vereist aanpak (methode), doorgaan (resultaatgericht) en perfectioneren (doelgericht). Zijn adagium was kennis is macht (om te vernieuwen) en aldus heeft hij onder andere de extensieve tulpenbollenteelt binnen het agrarische beroep geïntroduceerd. Met deze innovatie op 'het Nieuwe Land' deed hij met vele anderen de Noordoostpolder letterlijk eer aan. De tulp is een bolgewas in vele soorten en kleuren en geldt als één van de sterkste gewassen die de winter overleven. Gecultiveerde teelt vereist zorgvuldige en intensieve behandeling, waarbij speciële kennis en ervaring noodzakelijk zijn en als kleine jongen ben ik daarmee opgegroeid. $\mathrm{Er}$ zijn verschillende stadia in het kweekproces te onderscheiden welke fasegewijs volgens een algoritme jaarlijks terugkeren. Deze intensieve aanpak is nodig om resultaten te zien, maar het kan ook je persoonlijke leven gaan beheersen. Men zegt dan 'het is niet je baan, het is je leven'. In analogie hiermee lijkt het soms wel op promotie onderzoek. De overeenkomst met de tulp, die in deze thesis is gelegd wordt duidelijker als we deze mooie bloemen met vele blaadjes op de achterkaft zien als metafoor voor nieuw opgespoorde COPD patiënten die zich presenteerden als kleurrijke individuen met veelvoudige klachten. Hiermee wil ik dit proefschrift aan mijn vader opdragen vanuit een gevoel van persoonlijke bewondering en waardering.

In 1974 ben ik gevraagd door Professor Dr NGM Orie, longarts UMC te Groningen om studentassistent te worden en heb ik deelgenomen aan een onderzoek naar "ernstige irreversibele astma (CARA) patiënten". Gedurende ruim vier jaren hadden we regelmatig overleg in de pastorie te Winsum. Toen ik kennis had gemaakt met de hond des huizes, genaamd Cara, wist ik dat dit astma onderzoek wel heel belangrijk moest zijn. We denken nu aan COPD, maar die term bestond toen nog niet. Aan het einde van mijn studie geneeskunde bood Orie mij een promotietraject aan met opleiding tot longarts. Echter, ik wilde eerst huisarts worden. De ontwikkelingen op het gebied van astma en COPD lieten mij niet meer los en 32 jaren later (2011) ben ik alsnog gestart met uitdagend promotie onderzoek. De bezielende begeleiding van Prof Orie heeft iets met mij gedaan en daarvoor ben ik hem zeer erkentelijk.

Onno van Schayck, beste Onno, de opleiding tot kaderhuisarts astma/COPD in 2004 heeft me een boost gegeven tot extra verdieping in astma en COPD. Nadat ik huisartsencursussen kon gaan organiseren voor de regio 
Ede/Wageningen, ontmoette ik je in 2007 voor het eerst op een congres te Lunteren. Je hebt toen een onuitwisbare indruk op mij gemaakt als spreker. Ten overstaan van een overvolle zaal wist je op interactieve wijze, rondlopend met een microfoon, het publiek op levendige wijze te boeien. Dit bereikte je nota bene door van gedachten te wisselen over minder sexy onderwerpen als stoproken beleid bij COPD en knelpunten bij diagnostiek, maar je had de zaal geheel op de hand. In de periode daarna heb ik je gevraagd om mij te begeleiden bij een artikel over vroegopsporing van COPD. Dat was koren op jouw molen. Jij hebt me uiteindelijk gevraagd om te gaan promoveren, maar daar voelde ik me een beetje te oud voor. Ik ging overstag toen je aanhaalde dat oudere en gerijpte huisartsen zeer welkom waren voor promotie onderzoek, omdat de insteek van ervaring nogal verschilde van de jonge promovendi. Je hebt op zinvolle wijze richting gegeven en vertrouwen in mij gesteld tot op de dag van vandaag. Daarvoor ben ik je veel dank verschuldigd.

Jean Muris, beste Jean, als een van mijn vaste begeleiders en kersverse hoogleraar en hoofd van de Huisartsopleiding Maastricht heb ik je leren kennen als een gesprekspartner die zich bedient van weloverwogen argumentatie en de menselijke maat. Soms ook onderkoeld, zoals na een sms-berichtje; 'niet aanwezig wegens een bommelding, tot de volgende keer'. Naast humor heb ik je ook leren kennen als iemand die medeleven toont. Bij de correctie van een artikel kun jij lange zinnen snel reduceren en de hoofdzaken laten zien in puntige en spitse bewoordingen. Ik heb er veel aan gehad en wil je daarvoor dank zeggen.

Huibert Tange, beste Huibert, het is me altijd bijgebleven dat je medio 2012 heel snel als eerste na enige excel berekeningen wist te melden dat onze RCT "hele interessante resultaten opleverde". Je stond altijd voor me klaar om zaken uit te leggen. En het viel me op dat je mooie Engels zinnen kan produceren die het wetenschappelijke jargon eer aan doen. Je hebt een analytische geest waarbij je kritisch kan zijn. Je hebt me geleerd om steeds de puntjes op de "i" te blijven zetten. Maar je hebt ook oog voor de grote lijn en je weet heel goed systematisch overzicht te houden. Ik heb jouw adviezen in de 'vragende vorm' erg gewaardeerd. Bij deze vraag ik je om mijn dank te aanvaarden.

Mascha Twellaar, beste Mascha, we hebben in de eerste periode vrij veel samengewerkt. Dat ging dan meestal per email waarbij ik bijna altijd antwoord kreeg op mijn vraag. Je werkte accuraat en leverde altijd alles tijdig aan. Je was de enige met een sfeervolle bloemetjes layout op elk email bericht. Ik wil je danken voor de prettige samenwerking. 
Bjorn Winkens, beste Bjorn, ik kon altijd 'even' bij je terecht voor 'complexe' vragen, terwijl je geen structurele begeleider was. Echter, opvallend was jouw invoelend vermogen om snel te taxeren waar de schoen wrong. De relaxte wijze waarop je complexe informatie vaak gericht en eenvoudig op mij kon overbrengen werkte relativerend. Ik wil je dank zeggen voor jouw duidelijke uitleg van zorgprocessen met behulp van een statistische bril.

Albine Moser, beste Albine, als begeleider van de diepte-interview studie ging je altijd met veel enthousiasme een bespreking in. Dit gebeurde ofwel op het huisartsinstituut, soms op de Hogeschool Heerlen en ook al eens in de aula. Je had de stukken altijd goed voorbereid en je wilde me ook graag informatie 'meegeven' opdat ik er iets aan zou kunnen hebben. Ik heb altijd op een zeer prettige wijze met jou kunnen communiceren. Jij staat bekend als specialist op gebied van diepte-interview studies en ik was heel blij met jouw begeleiding. Daarvoor veel dank.

Guus Asijee, beste Guus, jij hebt mede de eerste versies van de telefonische screen studie becommentarieerd. Ten gevolge van jouw inzet, om een unrestricted grant te regelen, kon onze eerste studie doorgang vinden. Jij hebt zelf ook een promotietraject afgerond en je bent een snelle jongen, die 'to the point' redeneert. Dit komt in jouw beroep allemaal van pas. Maar jouw grote kracht schuilt erin dat je gewoon ook jezelf blijt. Met dank voor jouw inbreng.

Astrid van Hamersveld, beste Astrid, jij bent de drijvende kracht geweest om de spirometrieën projectmatig af te wikkelen in onze praktijk. Jij was er al vanaf het eerste uur en je werkte me e aan de eerste studie van deze thesis. Wij hebben al die jaren wekelijks COPD/astma patienten overleg en ik geloof dat het ons beiden altijd weer blijft boeien. Top. Ik ben je zeer erkentelijk voor jouw positieve inzet en nimmer aflatende bewogenheid ten aanzien van het verhaal van de patient. Dank je wel.

Michel Rutgers, beste Michel, als directeur van het Longfonds heb ik met jou als eerste een glas champagne geheven op het akkoord tussen Longfonds, NHG en Universiteit Maastricht om een grote COPD vroegopsporingsstudie te gaan realiseren. Dat was op de ERS te Barcelona in September 2010 en ik vergeet het nooit meer. Het was overigens maar afwachten of de studie iets zou gaan opleveren. Maar uit een eerste telefonische studie had ik al resultaten kunnen overleggen, met weliswaar zekere evidence. Dank voor het door jou gestelde vertrouwen.

Gerrit Vink, beste Gerrit, we hebben elkaar in 2012 vrij intensief ontmoet. Je was projectleider bij het toenmalige Astmafonds en je hebt de onderzoeksgroep 
vergaderingen voorgezeten op concrete en enthousiaste wijze. Het viel me op dat je meer rechtop ging zitten als het over "lage SES praktijken" ging. Je wilde ook graag mee om deze praktijken te visiteren en was als eerste aanwezig in een praktijk op Kanaleneiland te Utrecht. Door jouw praktische inbreng werd je voor mij een echte mede-auteur. Dank voor jouw inbreng.

Ton Drenthen, beste Ton, als medewerker van het Nederlands Huisartsen Genootschap (NHG) hebben we elkaar vooral ontmoet op de vergaderingen bij het Longfonds. Jouw houding was plezierig maar ook doortastend en daarvoor wil ik je dank zeggen.

Karin van Haaren, beste Karin, jij was afgevaardigde van het NHG in de onderzoekswerkgroep vroegopsporing. Als collega, onderzoeker en auteur van 'het Preventieconsult COPD' is jouw inbreng een waardevolle toevoeging geweest. Dank voor jouw kritische inbreng.

Jan Hesp, beste Jan, je was er bij om het onderzoeksproject uit te voeren. Je faciliteerde de praktijken met een helpdesk functie, computeruitdraai, mail merge, website codes, begeleiding van de spirometrieverpleegkundigen en aanlevering van excel databestanden. Kortom heel veel.... Onder jouw hoede kon de logistieke coördinatie nooit misgaan; appeltje, eitje. Jouw ondersteuning en inzet is van grote waarde gebleken en daarvoor wil ik je dank zeggen. Ik hoop nog vaker met je te kunnen samenwerken.

Hubert Maljaars, beste Hubert, we werken tien jaar samen in huisartsenpraktijk 'Renswoude' tot ieders grote tevredenheid. Altijd enthousiast voor vernieuwing en kritisch op eventuele knelpunten. Over vroegopsporing gesproken... Je hebt me ontzettend goed geholpen bij het inkloppen van de gegevens van alle praktijken in één databestand. Zorgvuldige bewaking van digitale informatie kun je rustig aan jou overlaten en bleek onmisbaar bij het onderzoek. Daarom ben ik je veel dank verschuldigd. .

Frank Wilschut, beste Frank, we waren vaak een sprekersduo voor de huisartsencursussen in Ede maar ook bij de 'nascholingen op grote hoogte' in Oostenrijk. Als longarts in de Gelderse Vallei stond je altijd open voor de inhoudelijke ondersteuning tav astma en COPD. Ik waardeer onze zeer prettige samenwerking, waarvoor dank. En nu nog de 'Tulpenralley'....

Jeroen Verheul, beste Jeroen, we hebben al een heel aantal CASPIR en refresh cursussen gegeven. Het viel me op dat jij als longarts echt heel enthousiast en bevlogen wordt als het over casuïstiek presentaties gaat. Je staat echt met 
beide benen in de klinische zorg en die willen huisartsen graag uitwisselen. Met dank voor jouw inbreng, ga zo door.

Ivo Smeele, beste Ivo, de manier waarop je met tomeloze energie onderzoek doet, huisarts bent en jarenlang de rol van CAHAG voorzitter vervulde, imponeerde mij. Op congressen viel het me op dat je frequent naar de laptop greep om de vergaarde nieuwe informatie 'en passant' vast te leggen. Jouw betrokkenheid met je werk, onderzoek, organisatie en patienten heeft mij geïnspireerd.

Rob van den Berg, beste Rob, we zijn via de Junior Kamer en later bij VERA ware en oprechte vrienden geworden. Een grotere optimist dan jij ken ik niet. Als ex-ontwikkelaar en creatief vormgever kruisen onze wegen elkaar zoals bij het nieuwe gezondheidscentrum Renswoude maar ook bij de kaft van dit boekje. Hierbij speciale dank voor jouw accurate inzet.

Het Barnevelds Kamerorkest, Victor Ploos van Amstel, beste Victor en allen met wie ik vanaf het eerste uur samenspeelde. Steeds als ik met mijn dubbele baan van huisarts en onderzoeker op de dinsdagavonden in het orkest kwam repeteren leverde me dat een waar gevoel van grote ontspanning op. Alsnog bedankt dat jullie mij indertijd hebben geaccepteerd als beginnend contrabassist in het orkest. Daardoor ging ook het onderzoekswerk beter.

Clemens Dirven, beste broer, al vele jaren wisselen wij persoonlijke ervaringen en ook inhoudelijke medische deskundigheid uit tot beider genoegen. Steeds heb je in de loop van mijn promotie traject stimulerende woorden gesproken, waarbij we naast de inhoudelijke aspecten vooral de informele beleving konden delen. Dat was voor mij uniek en belangrijk. Hiervoor wil ik je toch één keer formeel dank zeggen.

Alle personeel in de huisartsenpraktijk 'Renswoude' wil ik dank zeggen voor hun getoonde flexibiliteit; Alice de Ruiter, Anita Beek, Joanne van de Pol, Isabeau Buisman, Tiny van Wakeren, Marian Bunnik, Martijn Sonnenberg, Margreeth Luten, Drieka Bac, Corrie Jansen en speciaal Teuny Legemaat vanwege haar creatieve en toegewijde inzet. Een promotietraject is best intensief en daarom heb ik minder gewerkt in de praktijk. Dit vereiste van de praktijkassistentes extra aandacht om vragen van patiënten te kanaliseren.

Marlene en Lara Dirven, lieve dochters, als studenten hebben jullie op mijn verzoek direct aangeboden om te helpen met het verbatim typewerk van de lange diepte-interviews. Dit uiterst intensieve karwei hebben jullie met enthousiasme aangepakt en tevens succesvol afgerond ondanks de drukte met 
jullie beider studies. Op mijn vraag of jullie ceremoniemeesters wilden zijn weerklonk een volmondig jaaaaaa.

Ik zeg jullie hierbij dank en 'cum grano salis'.

Thomas Dirven en Richard Dirven, beste Thomas je bent mijn zoon en een zeer gemotiveerde student geneeskunde. Je hebt vele capaciteiten maar ook een beetje in de voetsporen van pa, ik ben er trots op. Ik ben blij dat jij en Richard paranymfen willen zijn. Beste Richard, als relaxte neef heb je tijdens je basisstudie bijna fluitend je promotietraject KNO afgerond. Voor jou leek dit amper een klus, maar indertijd vroeg je me: "oom, zou je nu wel echt willen gaan promoveren?" Ik weet nu inderdaad dat het intensief is, maar ook zo leuk.

Lieve Pauline, jij bent mijn echtgenote, huisarts-collega, maatschapsgenoot, duo- opleider, hagropartner, cooperatiegenoot en kritische noot... Tja, we lijken met handen en voeten aan elkaar gebonden. Gelukkig maar, want mijn leven met jou is sinds 26 jaren dagelijks een klein feestje. Altijd preventief op zoek naar oplossingen als de situatie uit de hand dreigt te lopen. Het einde was even zoek toen we op mijn verjaardag 's avonds tussen half 11 en half 12 werden weggeroepen, ieder voor een bevalling. Het werd zo hilarisch dat de gasten het feest verder hebben gevierd zonder gastheer en gastvrouw. Over praktijkdrukte gesproken; van deze onvoorziene situatie had zelfs jij niet terug. Als projectcoordinator kruiste ik in 2012 gedurende een half jaar met de auto langs de praktijklocaties in midden- en zuid-Nederland om het onderzoek rond te kunnen krijgen. Maar ondertussen hield jij met waarnemer en aios de praktijk draaiende. Beiden nogal hectisch kun je wel zeggen. Ik wil je dank zeggen voor jouw geduld, actieve inzet en hulp met verrassend vernieuwende ideeën. 

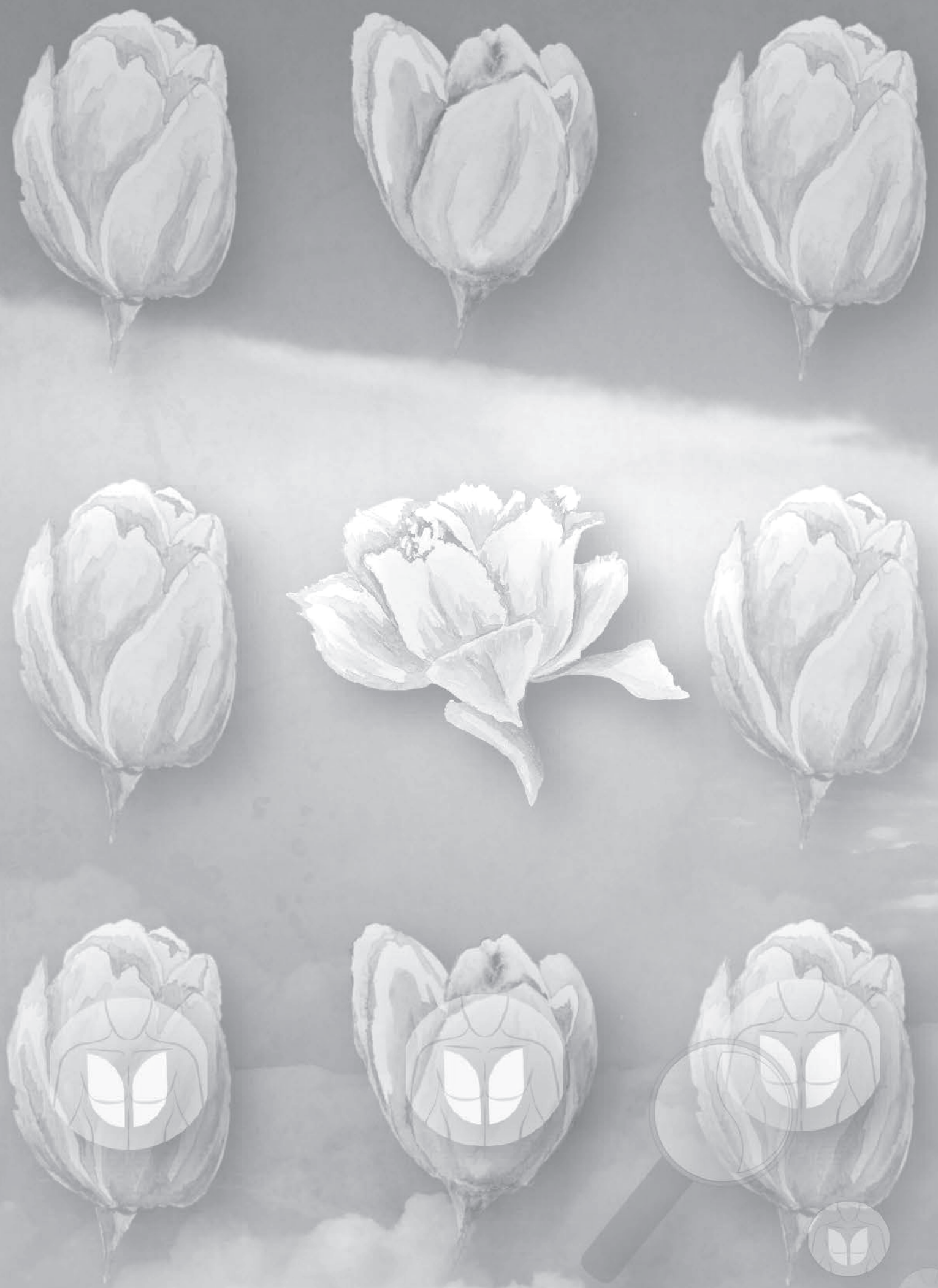


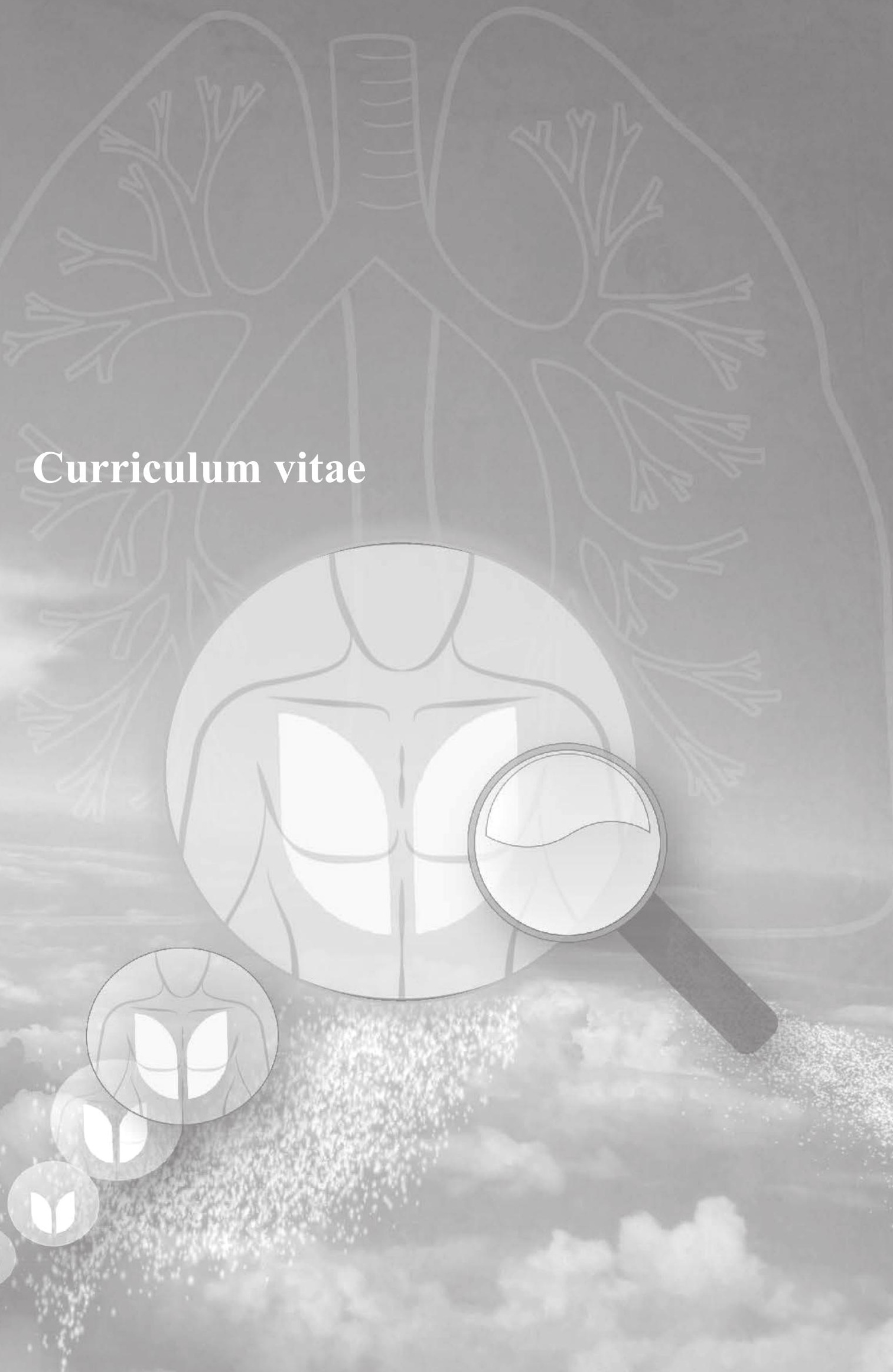




\section{Curriculum vitae}

Josephus Antonius Maria Dirven was born in the Noordoostpolder (the Netherlands) on 6 May 1954. He received his secondary school diploma in 1971 at the Ter Veen Lyceum in the town of Emmeloord, after which he started studying medicine at Groningen University. As a student, he worked as a research assistant from 1974 to 1977, and also participated in research to improve the management of patients with refractory CARA, under Prof. N.G.M. Orie at the department of pulmonology of the Groningen University Hospital. He did an elective internship on 'methodology in epidemiological research' at Muhimbili University in Dar-es-Salaam, Tanzania. He obtained his medical degree in March 1980, after which he did several internships in general surgery and gynaecology/obstetrics. He fulfilled his military service at the Utrecht Military Hospital, and attended a part-time philosophy degree course at Utrecht University. He completed the family medicine specialty training program at Erasmus University Rotterdam in 1985, after which he was a locum doctor in various general practices. From 1986 to 1990 he worked as a general practitioner for the Ballast-Nedam firm in Riyadh, Saudi-Arabia.

In 1990 he started a general practice together with his wife in the village of Renswoude. For research purposes, the practice is part of a regional cooperative of general practices called 'Nijmeegse Universitaire Huisartsen Praktijken', and since 1992 he has been a GP supervisor for the family medicine specialty training course for the Radboud University Medical Center in Nijmegen. From 1995 to 2000 he chaired the task force for professional development among general practitioners (Werkgroep Deskundigheidsbevordering Huisartsen) for the Gelderse Vallei region, in the town of Ede. He attended a training course to become a general practitioner specialist in asthma and COPD and a certified Quality Consultant (EKC). For this he is on the register of the Dutch College of General Practitioners with Special Expertise (College voor Huisartsen met Bijzondere Bekwaamheden, CHBB) of the Dutch College of General Practitioners in Utrecht. Since 2007 he has been an active member of the general practitioners' task force on COPD and asthma (COPD en Astma Huisartsen Groep, CAHAG). From 2008 to 2011 he chaired the National Association of General Practice Trainers (Landelijke Huisartsen Opleiders Vereniging) and was a member of the general board of the Dutch national general practice training course (Huisartsopleiding Nederland) in Utrecht. From January 2011 he was an external PhD student at the Department of Family Medicine and the CAPHRI research institute at Maastricht University. His hobbies include playing the double bass. He is married to Pauline and they have two daughters and one son. 

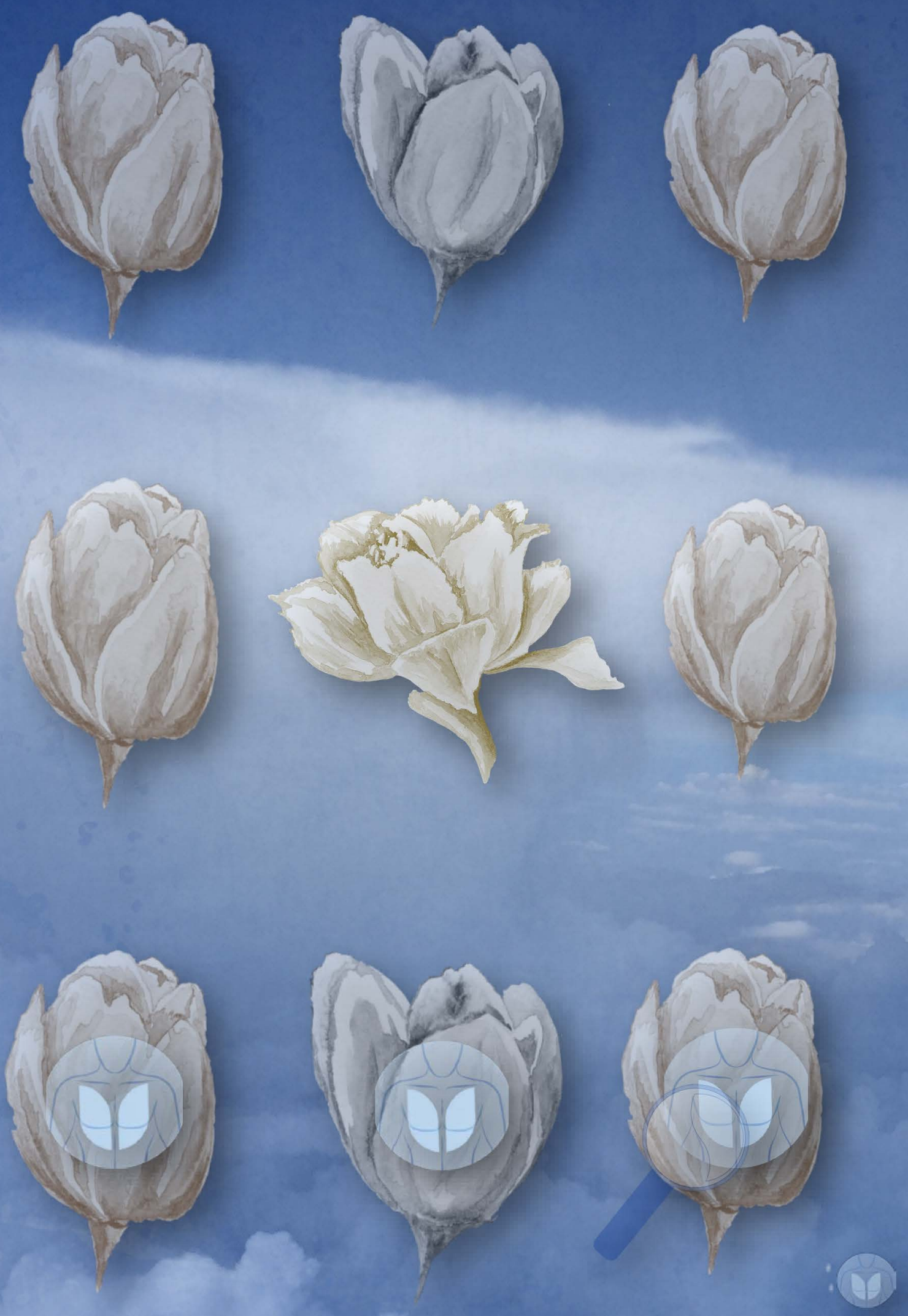